AN EPIDEMIOLOGICAL APPROACH TO ELUCIDATE DOPAMINERGIC MECHANISMS IN TARDIVE

DYSKINESIA IN SCHIZOPHRENIA 
Copyright (C) Diederik Egbert Tenback, Maastricht, 2006

ISBN-10: 90-5278-569-4

ISBN-13: 978-90-5278-569-1

Universitaire Pers Maastricht 


\title{
AN EPIDEMIOLOGICAL APPROACH TO ELUCIDATE DOPAMINERGIC MECHANISMS IN TARDIVE DYSKINESIA IN SCHIZOPHRENIA
}

\author{
PROEFSCHRIFT \\ ter verkrijging van de graad van doctor aan de Universiteit Maastricht, \\ op gezag van de Rector Magnificus, Prof. mr. G.P.M.F. Mols, \\ volgens het besluit van het College van Decanen, \\ in het openbaar te verdedigen op \\ woensdag 25 oktober 2006 om 12.00 uur.
}

door

Diederik Egbert Tenback

geboren op 25 augustus 1964 te Poortugaal

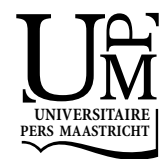


Promotor

Prof. dr. J.J. van Os

Copromotores

Dr. P.N. van Harten (Symfora Groep Amersfoort \& Rijksuniversiteit Groningen)

Dr. C.J. Slooff ～(GGZ Drenthe \& Rijksuniversiteit Groningen)

Beoordelingscommissie

Prof. dr. F.R.J. Verhey (voorzitter)

Prof. dr. R.S. Kahn (Universiteit Utrecht)

Dr. H. Knegtering (Rijksuniversiteit Groningen)

Prof. dr. M. Limburg

Prof. dr. H.M. van Praag

Publication of this thesis was financially supported by Eli Lilly B.V. 


\section{CONTENTS}

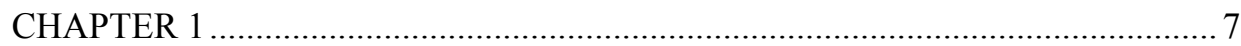

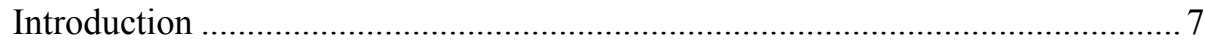

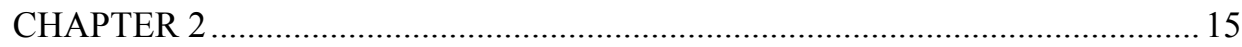

Methodology and treatment characteristics of the SOHO study......................... 15

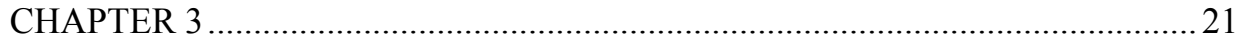

Little Evidence of Risk factors for Onset of Tardive Dyskinesia in

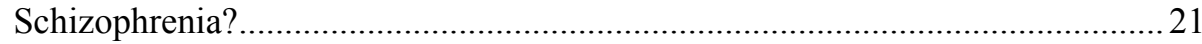

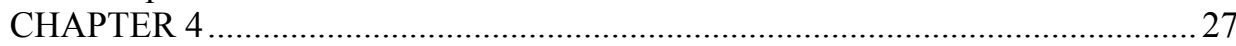

Effects of Antipsychotic Treatment on Tardive Dyskinesia: A 6-Months Evaluation of Patients From the European Schizophrenia Outpatient Health

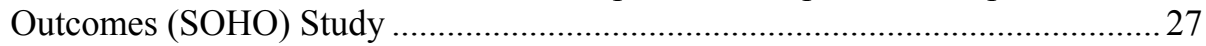

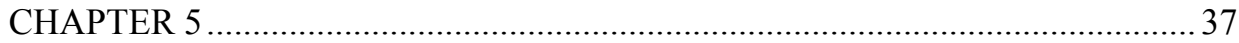

Evidence That Early Extrapyramidal Symptoms Predict Later Tardive Dyskinesia: A Prospective Analysis of 10,000 Patients in the European Schizophrenia Outpatient Health Outcome (SOHO) Study.................................. 37

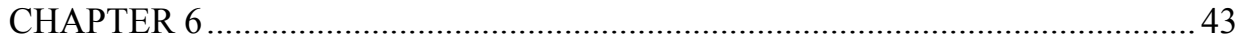

Tardive Dyskinesia in Schizophrenia is Associated with Prolactin-Related Sexual

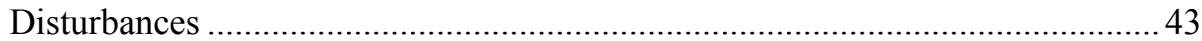

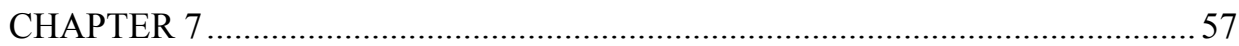

Tardive Dyskinesia and Worsening of Psychosis: More than Just the Nigrostriatal

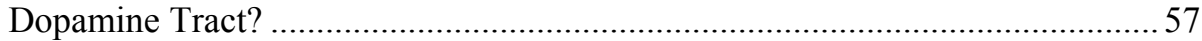

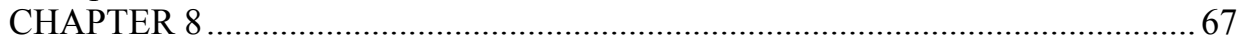

Incidence and Subsequent Persistence of Tardive Dyskinesia and Extrapyramidal Symptoms in Schizophrenia: Markers of Progressive Dopamine Sensitivity?.... 67

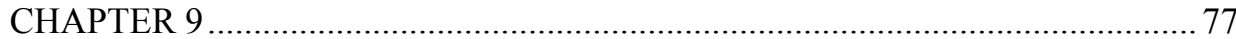

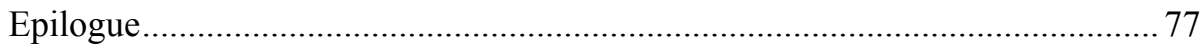

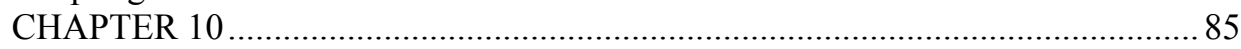

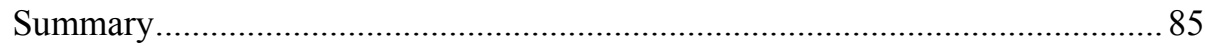

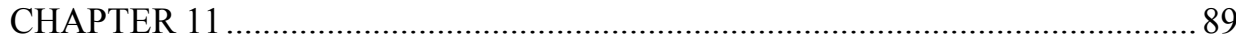

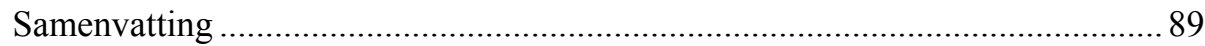

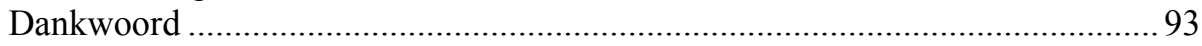

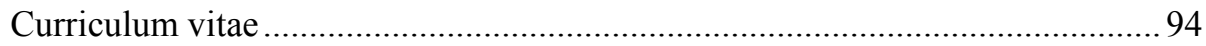

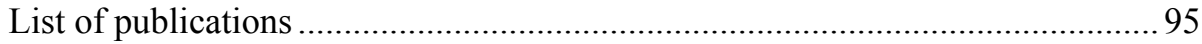





\title{
CHAPTER 1
}

\section{Introduction}

\author{
Schizophrenia
}

Schizophrenia is a debilitating illness affecting around $1 \%$ of the population (Arajarvi, Suvisaari et al. 2005). Research suggests that schizophrenia is a disease with a genetic liability, which, in interaction with environmental risk factors, may become expressed (Van Os and McGuffin 2003). Overall, however, its aetiology remains poorly understood.

Tardive dyskinesia (TD), a movement disorder occurring in schizophrenia,is characterized by involuntary, choreoathetoid, movements in the orofacial region, limbs, trunk and respiratory system. TD can develop not only in patients with schizophrenia, but also in patients with other diagnoses when treated with antipsychotics. Most clinicians view TD in schizophrenia as an antipsychotic related side effect, yet relatively little is known about the aetiology of TD, the clinical consequences of its diagnosis, and its treatment.

Many hypotheses about the pathophysiology of TD are brought forward in the literature, these include: pharmacogenomics, the dopamine supersensitivity theory, GABA insufficiency theory, glutamate striatal excitotoxicity theory, as well as loss of cholinergic neurons (Miller and Chouinard 1993; Cadet and Kahler 1994; Klawans 1973; Muller, Shinkai et al. 2004; Kulkarni and Naidu 2003). This listing is not complete, nor, probably, mutually exclusive, it does, however, illustrate the complexity of the pathogenesis of TD which remains elusive.

\section{Dopamine}

This thesis focuses on the dopamine system and the dopamine hypothesis of schizophrenia, other neurotransmitters are left beyond its scope.

Dopamine is a neurotransmitter belonging to the catecholamine family. Dopamine is involved in the regulation of the hormonal-, gastrointestinal -, cardiovascular-, renal-, and central nervous systems. There are 5 subtypes of the dopamine receptor (D1-5). The D1 family includes the D1 and D5 receptors, the dopamine D2 family includes D2, D3 and D4 receptors (Palermo-Neto 1997). Our attention will be centered on the Dopamine D2 receptor prevalent in the pituitary, striatal and limbic systems, as well as the substantia nigra. Although in reality more complex, the dopamine system can be divided in dopamine tracts, in the literature commonly re- 
ferred to as the mesolimbic, mesocortical, tuberoinfundibular and nigrostriatal tracts. The different dopamine tracts are thought to be associated with the symptom clusters and motor symptoms of schizophrenia. The mesolimbic tract is associated with positive symptoms, the mesocortical tract with cognitive and negative symptoms, the tuberoinfundibular tract with prolactin regulation, and finally the nigrostriatal tract with motor symptoms of schizophrenia. Two dopamine hypotheses will subsequently be briefly discussed; the dopamine hypothesis of schizophrenia followed by the dopamine hypothesis of tardive dyskinesia.

\section{The Dopamine Hypothesis of Schizophrenia}

The Dopamine hypothesis of schizophrenia is based on the concept that all antipsychotics act through the mechanism of dopamine blockade, combined with the observation that substances which enhance dopaminergic transmission mimic psychotic symptoms. This concept seems validated in first episode patients with schizophrenia, where the degree of striatal receptor occupancy by haloperidol predicts clinical improvement, hyperprolactinemia and extrapyramidal side effects, with an increased probability of clinical response, hyperprolactinemia or extrapyramidal side effects when D2 occupancy exceeds 65,72 or $78 \%$ respectively, corroborating the clinical importance of dopamine in schizophrenia (Kapur, Zipursky et al. 2000). Elaborating on the dopamine hypothesis of schizophrenia two mechanisms are postulated to be related to the liability for schizophrenia: i) increased caudate D2 density up-regulation and ii) increased high affinity state of the dopamine receptor (Seeman 2002). Underlying postulated mechanisms causing supersensitivity in animal models are numerous and include hippocampal lesions, antipsychotics, ethanol, amphetamine, phencyclidine, gene knockouts of dopamine beta-hydroxylase, Drd4 receptors, G protein-coupled receptor kinase 6, catechol-Omethyltransferase, or Th-/-, DbhTh/+ (tyrosine hydroxylase), N- methyl-d-aspartate (NMDA) dysfunction, and Cesarean-section (Laruelle, Frankle et al. 2005; Seeman, Weinshenker et al. 2005; van Berckel, Kegeles et al. 2006). In humans amphetamine, phencyclidine, steroids, ethanol, and brain lesions such as hippocampal, cortical, and entorhinal lesions can lead to psychosis and dopamine supersensitivity (Seeman, Schwarz et al. 2006). However, functional and association studies in humans of e.g. Drd4, COMT, and Dopamine beta-hydroxylase are not conclusive (Jonsson, Abou Jamra et al. 2003; Ehlis, Reif et al. 2006; Mitsuyasu, Kawasaki et al. 2006; Numata, Ueno et al. 2006; Srivastava, Varma et al. 2006; Szoke, Schurhoff et al. 2006).

\section{The Dopamine Hypothesis of Tardive Dyskinesia}

The dopamine hypothesis of schizophrenia is also one of the leading hypotheses in tardive dyskinesia; the nigrostriatal system develops increased sensitivity to dopamine as a consequence of chronic dopamine receptor blockade when exposed to antipsychotic therapy (Casey 2000). Most concepts regard the phenotype tardive dyskinesia yet do not distinguish tardive dyskinesia or dyskinesia with regard to the 
underlying psychiatric diseases (Margolese, Chouinard et al. 2005). The validity of these concepts is equivocal: schizophrenia is the only psychiatric disease in which patients never treated with antipsychotics, exhibit signs of TD, in contrast to patients with other psychiatric diagnoses who will develop TD only during antipsychotic treatment, thus suggesting that increased D2 density or high affinity states in schizophrenia might be potentiated by antipsychotic dopamine blockade but need not be a conditio sine qua non (Casey 2000; Fenton 2000). Thus, it seems plausible that tardive dyskinesia induced by antipsychotic therapy, and dyskinesia in fist episode patients with schizophrenia might share their phenomenology, possibly even some pathophysiology, but not their aetiology. The concept of dyskinesia as a core symptom of schizophrenia is further illustrated by the prevalence of spontaneous dyskinesia in never treated patients, ranging from $4 \%$ in first episode, to $12 \%$ for patients who have been ill for several years and less than 30 years of age, to $25 \%$ for never treated patients between 30 and 50 years of age, and finally $40 \%$ for those patients aged 60 years and older (Fenton 2000). These prevalence rates in never treated patients are roughly within the same ranges as those reported in patients treated with antipsychotics (Owens, Johnstone et al. 1982; Guy, Ban et al. 1986; Altamura, Cavallaro et al. 1990; McCreadie, Robertson et al. 1992; Puri, Barnes et al. 1999). However, when comparing studies reporting on both dyskinesia (never treated with antipsychotics) and tardive dyskinesia (treated with antipsychotics) in a population of patients with schizophrenia, both present more or less similar prevalence rates in patients for the never exposed and in those exposed to antipsychotics groups (Owens, Johnstone et al. 1982; McCreadie, Thara et al. 1996), although not all studies endorse these findings (McCreadie and Ohaeri 1994). The data seems to suggest that antipsychotics merely have a potentiating effect. Moreover, these studies date back to the fist generation antipsychotics era, and since first generation antipsychotics are a risk factor for tardive dyskinesia compared to second generation antipsychotics (Correll, Leucht et al. 2004) the question arises if second generation antipsychotics are a risk factor for tardive dyskinesia at all.

If first generation antipsychotics simply have a potentiating effect and dyskinesia is a core symptom of schizophrenia, it follows that dyskinesia could reflect a vulnerability of the dopamine system. Evidence for a genetic role is derived from sibling studies where patients with schizophrenia exhibit more TD symptoms than their unaffected siblings, who in turn exhibit more TD symptoms than normal controls (Egan, Hyde et al. 2001). Furthermore, siblings of patients with schizophrenia and dyskinesia have a higher rate of dyskinesia than siblings of patients with schizophrenia without dyskinesia (Muller, Schulze et al. 2001; McCreadie, Thara et al. 2003), suggestive of a subgroup of patients with schizophrenia combined with motor symptoms. Dyskinesia might serve as a potential marker for a vulnerability to schizophrenia, as having unusual movements during childhood predicts schizophrenia in adulthood (Walker, Savoie et al. 1994; Rosso, Bearden et al. 2000). Clinically tardive dyskinesia is longitudinally linked to poor outcome in schizophrenia (Chatterjee, Chakos et al. 1995; Strous, Alvir et al. 2004). Finally COMT and Drd4 have been implicated as possible genes linking dopamine sensitivity, tardive dyskinesia and schizophrenia (Srivastava, Varma et al. 2006) 
Although the dopamine hypothesis has properties linking genetics, early and late motor symptoms and positive, negative, and cognitive symptoms of schizophrenia, the hypothesis itself is incomplete, it does not offer an explanation for the various temporal effects observed when administering antipsychotic therapy. D2 occupancy is achieved rapidly whereas response to treatment is not, when response is accomplished, relapse does not occur immediately when antipsychotic therapy is stopped, extrapyramidal symptoms develop rapidly where tardive means "late occurring", suggesting D2 blockade is requisite, but other unknown pathways are involved.

The vulnerability of the nigrostriatal dopamine system possibly extends to other dopamine tracts as suggested by early cognitive symptoms in childhood which predict the occurrence of schizophrenia (Erlenmeyer-Kimling, Rock et al. 2000). If a pandopaminergic involvement exists, what are the environmental risk factors influencing a possible genetic liability? Finally, can a theoretical model, integrating the different aforementioned aspects, be developed, which could serve as an avenue for further research into the pathogenesis of schizophrenia?

\section{Epidemiological Approach to Test Neurobiological Hypotheses}

The current thesis addresses hypotheses regarding the role of dopamine pathways in tardive dyskinesia using a novel epidemiological approach. While neurobiological paradigms may be useful in targeting specific dopamine pathways experimentally, they are extremely difficult and expensive, and only practicable in small and crosssectional samples. The epidemiological approach chosen in this thesis uses imperfect proxy measures of specific DA pathways, that nevertheless offer the unique advantage of the possibility of directly examining clinical hypotheses in a longitudinal design. The epidemiological approach therefore complements neurobiological paradigms in the study of the role of dopamine pathways in tardive dyskinesia.

\section{Outline and Aims of this Thesis}

In this thesis the relation between $\mathrm{TD}$, environmental factors, proxy measures serving as markers for the different dopamine tracts, and schizophrenia is explored.

To promote a deeper understanding of the subject under discussion, chapter 2 explains the methodology of the study in which all analyses, exploring the role of dopamine in TD in schizophrenia, were conducted. The strengths and weaknesses in regard to the research question are considered, and the demographics and treatment characteristics of the cohort of patients over the six months of the SOHO study in which the analyses were conducted are described.

Chapter 3 discusses the current body of evidence with regard to risk factors for TD in schizophrenia, using a meta analytic approach in search of the evidence on risk factors for the emergence of TD in schizophrenia. 
Subsequent chapters will discuss proxy measures for the different dopamine tracts and their association with TD, using a very large cohort of patients with schizophrenia.

The penultimate chapter describes the influence of risk factors on the dopamine tract, and will try to integrate the previous chapters by proposing a model bringing together schizophrenia, TD, the proxy measures, as well as the role of exogenous risk factors. A concluding chapter follows.

General aim of this thesis: to promote a better general understanding of the reasons why patients with schizophrenia develop tardive dyskinesia, as well as its clinical consequences. To achieve this better understanding the following questions were addressed:

The Current Body of Evidence on Risk Factors for TD in Schizophrenia.

Risk factors for TD have been studied extensively. However, most studies are either cross-sectional or retrospective, and conducted in diagnostically mixed populations. To asses the current level of evidence of risk factors for TD in schizophrenia, a meta analysis is presented in chapter 3 with an exclusive focus on true (i.e. following individuals without TD for prospectively assessed transition to TD) incidence of TD, concentrating on samples in which the majority of patients had a diagnosis of schizophrenia.

To compare First Generation Antipsychotics (FGA) with Second Generation Antipsychotics (SGA) not only with Regard to Incidence of TD but also with Regard to Persistence of TD.

There is a good level of evidence that second generation antipsychotics have a lower incidence of TD than first generation antipsychotics. Insufficient evidence exists for an ameliorative effect of second generation antipsychotics on TD. The analysis in chapter 4 presents prospective data on the persistence of TD between a cohort treated with FGA versus SGA.

Does EPS as a Proxy Measure for the Nigrostriatal Dopamine Tract Prospectively Predict TD in Schizophrenia.

EPS is a common condition when treating patients with schizophrenia. EPS is considered an adverse event of treatment with antipsychotic medication. The analysis in chapter 5 investigates the longitudinal relation between EPS and the incidence of TD in schizophrenia. 
Do Prolactin-related Sexual Disturbances (PRSD) as a Proxy Measure for the Tuberoinfundibular Tract Predict TD in Schizophrenia.

The nigrostriatal pathway is at the centre of theories on the causes of TD, any hypothesized pathophysiological mechanisms may, however, well extend to other dopamine tracts. Assuming this to be true, the rate of incidence of TD should be associated with indicators of dysfunction of other dopamine tracts, suggesting TD to be only one indicator of a much more widespread, pandopaminergic,dysfunctional state. The analysis in chapter 6 examines whether PRSD prospectively predicts TD.

Does Worsening of Psychosis Predict TD in Schizophrenia.

The aim of the analysis conducted in chapter 7 was to examine a proxy psychopathological measure of dopaminergic, mesolimbic, and mesocortical signaling in relation to the incidence of TD. However simple, global, measures of TD and CGI positive, negative, affective and cognitive symptoms, were best represented by a single CGI overall symptom severity score. Therefore, associations between TD onset and change in CGI scores were analyzed and subsequently hypothesized to reflect underlying changes in neurochemical signalling, using Cox proportional hazard regression.

The Morbidity Force of Movement Disorder in the Era of Second Generation Antipsychotics (SGA)

Many patients with schizophrenia are treated with SGA, these being associated with a lower incidence of TD than FGA. There is also some evidence that SGA may reduce the burden of existing TD. The aim of the analysis presented in chapter 8 is to assess the morbidity force of movement disorder in the era of second generation antipsychotics (SGA), by calculating the incidence and persistence of tardive dyskinesia (TD) and extra pyramidal symptoms (EPS) in a cohort of patients with schizophrenia treated predominantly with SGA, over a period of two years.

To Provide a Framework to Unite the Findings of the Different Analyses.

Chapter 9 provides a summary of the findings and creates a framework for Progressive Dopamine Sensitivity thus combining the findings of the different chapters into a coherent hypothesis. 


\section{REFERENCES}

Altamura, A. C., R. Cavallaro, et al. (1990). "Prevalence and risk factors for tardive dyskinesia: a study in an Italian population of chronic schizophrenics." Eur Arch Psychiatry Clin Neurosci 240(1): 9-12.

Arajarvi, R., J. Suvisaari, et al. (2005). "Prevalence and diagnosis of schizophrenia based on register, case record and interview data in an isolated Finnish birth cohort born 1940-1969." Soc Psychiatry Psychiatr Epidemiol 40(10): 808-16.

Cadet, J. L. and L. A. Kahler (1994). "Free radical mechanisms in schizophrenia and tardive dyskinesia." Neurosci Biobehav Rev 18(4): 457-67.

Casey, D. E. (2000). "Tardive dyskinesia: pathophysiology and animal models." J Clin Psychiatry 61 Suppl 4: 5-9.

Chatterjee, A., M. Chakos, et al. (1995). "Prevalence and clinical correlates of extrapyramidal signs and spontaneous dyskinesia in never-medicated schizophrenic patients." Am J Psychiatry 152(12): 1724-9.

Correll, C. U., S. Leucht, et al. (2004). "Lower risk for tardive dyskinesia associated with secondgeneration antipsychotics: a systematic review of 1-year studies." Am J Psychiatry 161(3): 414-25.

Egan, M. F., T. M. Hyde, et al. (2001). "Relative risk of neurological signs in siblings of patients with schizophrenia." Am J Psychiatry 158(11): 1827-34.

Ehlis, A. C., A. Reif, et al. (2006). "Impact of Catechol-O-Methyltransferase on Prefrontal Brain Functioning in Schizophrenia Spectrum Disorders." Neuropsychopharmacology.

Erlenmeyer-Kimling, L., D. Rock, et al. (2000). "Attention, memory, and motor skills as childhood predictors of schizophrenia-related psychoses: the New York High-Risk Project." Am J Psychiatry 157(9): 1416-22.

Fenton, W. S. (2000). "Prevalence of spontaneous dyskinesia in schizophrenia." J Clin Psychiatry 61 Suppl 4: 10-4.

Guy, W., T. A. Ban, et al. (1986). "The prevalence of abnormal involuntary movements among chronic schizophrenics." Int Clin Psychopharmacol 1(2): 134-44.

Hirvonen, J., T. G. van Erp, et al. (2005). "Increased caudate dopamine D2 receptor availability as a genetic marker for schizophrenia." Arch Gen Psychiatry 62(4): 371-8.

Jonsson, E. G., R. Abou Jamra, et al. (2003). "No association between a putative functional promoter variant in the dopamine beta-hydroxylase gene and schizophrenia." Psychiatr Genet 13(3): 175-8.

Kapur, S., R. Zipursky, et al. (2000). "Relationship between dopamine D(2) occupancy, clinical response, and side effects: a double-blind PET study of first-episode schizophrenia." Am J Psychiatry 157(4): 514-20.

Klawans, H. L., Jr. (1973). "The pharmacology of tardive dyskinesias." Am J Psychiatry 130(1): $82-6$.

Kulkarni, S. K. and P. S. Naidu (2003). "Pathophysiology and drug therapy of tardive dyskinesia: current concepts and future perspectives." Drugs Today (Barc) 39(1): 19-49.

Laruelle, M., W. G. Frankle, et al. (2005). "Mechanism of action of antipsychotic drugs: from dopamine $\mathrm{D}(2)$ receptor antagonism to glutamate NMDA facilitation." Clin Ther 27 Suppl A: S16-24.

Margolese, H. C., G. Chouinard, et al. (2005). "Tardive dyskinesia in the era of typical and atypical antipsychotics. Part 1: pathophysiology and mechanisms of induction." Can J Psychiatry 50(9): 541-7. 
McCreadie, R. G. and J. U. Ohaeri (1994). "Movement disorder in never and minimally treated Nigerian schizophrenic patients." Br J Psychiatry 164(2): 184-9.

McCreadie, R. G., L. J. Robertson, et al. (1992). "The Nithsdale schizophrenia surveys. IX: Akathisia, parkinsonism, tardive dyskinesia and plasma neuroleptic levels." Br J Psychiatry 160: 793-9.

McCreadie, R. G., R. Thara, et al. (1996). "Abnormal movements in never-medicated Indian patients with schizophrenia." Br J Psychiatry 168(2): 221-6.

McCreadie, R. G., R. Thara, et al. (2003). "Spontaneous dyskinesia in first-degree relatives of chronically ill, never-treated people with schizophrenia." Br J Psychiatry 183: 45-9.

Miller, R. and G. Chouinard (1993). "Loss of striatal cholinergic neurons as a basis for tardive and L-dopa-induced dyskinesias, neuroleptic-induced supersensitivity psychosis and refractory schizophrenia." Biol Psychiatry 34(10): 713-38.

Mitsuyasu, H., H. Kawasaki, et al. (2006). "Genetic structure of the dopamine receptor D4 gene (DRD4) and lack of association with schizophrenia in Japanese patients." J Psychiatr Res.

Muller, D. J., T. G. Schulze, et al. (2001). "Familial occurrence of tardive dyskinesia." Acta Psychiatr Scand 104(5): 375-9.

Muller, D. J., T. Shinkai, et al. (2004). "Clinical implications of pharmacogenomics for tardive dyskinesia." Pharmacogenomics J 4(2): 77-87.

Numata, S., S. Ueno, et al. (2006). "Interaction between catechol-O-methyltransferase (COMT) Val108/158Met and brain-derived neurotrophic factor (BDNF) Val66Met polymorphisms in age at onset and clinical symptoms in schizophrenia." J Neural Transm.

Owens, D. G., E. C. Johnstone, et al. (1982). "Spontaneous involuntary disorders of movement: their prevalence, severity, and distribution in chronic schizophrenics with and without treatment with neuroleptics." Arch Gen Psychiatry 39(4): 452-61.

Palermo-Neto, J. (1997). "Dopaminergic systems. Dopamine receptors." Psychiatr Clin North Am 20(4): 705-21.

Puri, B. K., T. R. Barnes, et al. (1999). "Spontaneous dyskinesia in first episode schizophrenia." J Neurol Neurosurg Psychiatry 66(1): 76-8.

Rosso, I. M., C. E. Bearden, et al. (2000). "Childhood neuromotor dysfunction in schizophrenia patients and their unaffected siblings: a prospective cohort study." Schizophr Bull 26(2): 367-78.

Seeman, P. (2002). "Atypical antipsychotics: mechanism of action." Can J Psychiatry 47(1): 2738.

Seeman, P., J. Schwarz, et al. (2006). "Psychosis pathways converge via D2high dopamine receptors." Synapse 60(4): 319-46.

Seeman, P., D. Weinshenker, et al. (2005). "Dopamine supersensitivity correlates with D2High states, implying many paths to psychosis." Proc Natl Acad Sci U S A 102(9): 3513-8.

Srivastava, V., P. G. Varma, et al. (2006). "Genetic susceptibility to tardive dyskinesia among schizophrenia subjects: IV. Role of dopaminergic pathway gene polymorphisms." Pharmacogenet Genomics 16(2): 111-7.

Strous, R. D., J. M. Alvir, et al. (2004). "Premorbid functioning in schizophrenia: relation to baseline symptoms, treatment response, and medication side effects." Schizophr Bull 30(2): 26578.

van Os, J. and P. McGuffin (2003). "Can the social environment cause schizophrenia?" Br J Psychiatry 182: 291-2.

van Berckel, B. N., L. S. Kegeles, et al. (2006). "Modulation of amphetamine-induced dopamine release by group II metabotropic glutamate receptor agonist LY354740 in non-human primates studied with positron emission tomography." Neuropsychopharmacology 31(5): 967-77.

Walker, E. F., T. Savoie, et al. (1994). "Neuromotor precursors of schizophrenia." Schizophr Bull 20(3): 441-51. 


\section{CHAPTER 2}

\section{Methodology and treatment characteristics of the SOHO study}

\section{INTRODUCTION}

The SOHO study is a 3-year, prospective, observational study of the health outcomes associated with antipsychotic treatment in Europe. Over 10000 patients have been recruited from 10 countries. Baseline evaluation included measures of clinical status, social functioning, quality of life, service use, side effects, compliance, substance abuse and pharmacological treatment. Originally the study was designed with two principal cohorts of patients diagnosed with schizophrenia, receiving treatment in an outpatient, ambulatory setting who either: i) initiated or changed to olanzapine therapy, or ii) initiated or changed to non-olanzapine antipsychotic treatment. No randomization was applied, the choice of pharmacological treatment was based on the clinician's decision. Few inclusion criteria were applied, patients: i) had to be at least 18 years of age, ii) should be diagnosed with schizophrenia and, iii) were being treated in an ambulatory setting. In addition to the baseline data collection, data were gathered at 3 and 6 months and at six months' intervals thereafter.

For the purpose of this thesis the SOHO study was analyzed as one large, prospectively followed, cohort irrespective of pharmacological treatment.

\section{General Considerations: Experimental Versus Non Experimental Designs}

In most epidemiological research the researcher is interested in causality. Hill's criteria for causation are referred to in several chapters. We would like to emphasize however, that although epidemiology can provide strong evidence for causality, this evidence is circumstantial.

In considering the limitations of observational studies, Pocock concludes that in the absence of rigorous experimental methodology, it is not possible to be certain that the findings of an observational study are as predictive as would be the results of a randomized, controlled trial (RCT). After all, experimental design involves randomization, the use of strict in- and exclusion criteria, and the rigorous use of stan- 
dard definitions of medical conditions (Pocock and Elbourne 2000). Besides the scientific rigor of experimental design, one can consider the issue of internal validations versus external generalization of study results (Wells 1999). Although RCTs render a high internal validity, meaning that the effect of the intervention of the experimental research is indeed attributable to the intervention, and not to bias, external validity, meaning generalization of results in relation to the treatment population in daily practice, is poor. The reason for this poor external validity is the use of many in- and exclusion criteria in RCTs which can be prevalent in daily clinical practice (Licht, Gouliaev et al. 1997). Another consideration is expenditure; for relatively rare outcomes large sample sizes are needed with equally large costs. Combining the above mentioned arguments, one could reason that an important difference between experimental and non experimental research is that in non experimental research the researcher can manipulate the levels of confounders with multivariate statistics, while randomly assigning patients to treatment in RCTs assumes similar levels of confounders in experimental research. The major distinction between the two designs is the influence of unknown confounders assumed equally divided in experimental research, where these are potentially biased in observational research, with a higher external validity of results for the latter. Although the chance of the presence of bias is higher in observational research, recent studies in different therapeutic areas show no major differences in effect sizes when comparing observational studies and RCTs (Kunz and Oxman 1998; Benson and Hartz 2000; Concato, Shah et al. 2000; MacLehose, Reeves et al. 2000), making observational studies an important tool in medical research.

\section{Considerations with Regard to the SOHO Study}

All analyses presented in this thesis are based on the cohort of the SOHO study described above. Further details on the patient cohort with regard to demographics, antipsychotic and concomitant treatment, compliance, and other factors potentially influencing emergence or persistence of TD, are described in Table 1.

When reading the next chapters, one should consider the following restrictions with regard to the interpretation of results presented there: i) the diagnosis of schizophrenia was based on clinicians' expert opinion as opposed to conducting a structured interview for establishing a diagnosis; ii) measurements of TD, EPS, sexual dysfunction and patient compliance were attained with non validated, categorical, measures; iii) for the purpose of analysis these measurements were further reduced to binary variables.

Further discussion of the methodological limitations posed by these variables on the different predictors of emergent TD will be found in the chapters relating to the various predictors themselves.

Finally, the most important covariates for the analyses performed will be pointed out throughout the different chapters of this thesis. A complete list of covariates included in the different analyses, as decided upon by the SOHO Advisory Board, is listed in Table 2. 


\begin{tabular}{|c|c|c|c|c|c|c|c|c|c|c|c|c|c|c|c|c|c|c|c|c|c|c|}
\hline 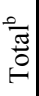 & \begin{tabular}{l}
\multirow{2}{0}{} \\
$\stackrel{1}{0}$ \\
0
\end{tabular} & $\begin{array}{l}\stackrel{\circ}{\mathrm{i}} \\
\stackrel{+}{+}\end{array}$ & $\frac{H}{\dot{q}}=$ & 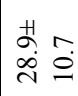 & $\begin{array}{l}\circ \\
\stackrel{0}{0}\end{array}$ & & \} $&{\stackrel{\circ}{\stackrel{0}{*}}} &{\mid \begin{array}{c|}\text { aे } \\
\text { aे }\end{array}} &{\begin{array}{l}0 \\
\vdots \\
\infty \\
-1\end{array}} &{\begin{array}{c}\stackrel{0}{\circ} \\
\infty \\
\infty\end{array}} &{\mid \begin{array}{l}\text { ذें } \\
\text { فे }\end{array}} &{\begin{array}{l}\stackrel{0}{0} \\
\dot{+}\end{array}} &{ } &{\begin{array}{l}0 \\
0 \\
0 \\
0\end{array}} &{\begin{array}{l}\text { dे } \\
\dot{0} \\
\dot{m}\end{array}} &{\text { 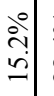 }} &{\text { 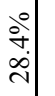 }} &{ } &{\text { 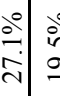 }} &{\text { 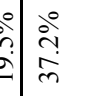 }} &{\text { o̊ }} \\
{\hline \begin{array}{l}0 \\
\hat{a} \\
\dot{4} \\
+ \\
v\end{array}} &{\begin{array}{l}\infty \\
\stackrel{0}{0} \\
\sim\end{array}} &{\text { 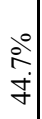 }} &{\text { 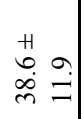 }} &{\text { 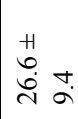 }} &{\begin{array}{l}0 \\
\grave{2} \\
a\end{array}} &{ } &{\text { 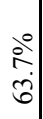 }} &{\text { 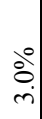 }} &{\mid \begin{array}{c}0 \\
0 \\
0 \\
0 \\
-1\end{array}} &{\begin{array}{l}\text { ఏे } \\
\text { ఏे }\end{array}} &{\begin{array}{l}0 \\
\stackrel{0}{0} \\
\stackrel{2}{-}\end{array}} &{\mid \begin{array}{l}\mid \\
\text { å } \\
\end{array}} &{\stackrel{\circ}{\grave{n}}} &{ } &{\begin{array}{l}0 \\
i \\
\infty \\
\infty\end{array}} &{\begin{array}{l}\text { iें } \\
\text { तें } \\
\end{array}} &{\begin{array}{l}0 \\
\infty \\
\dot{+} \\
\dot{v}\end{array}} &{\text { 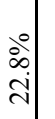 }} &{ } &{\text { 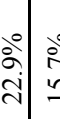 }} &{\begin{array}{ll}0 \\
\dot{2} \\
\dot{2}\end{array}} &{\text { 孛 }} \\
{\hline \begin{array}{l}\overrightarrow{0} \\
\stackrel{0}{0}\end{array}} &{\stackrel{\infty}{\infty}} &{\begin{array}{l}\stackrel{0}{0} \\
\dot{i} \\
\dot{j}\end{array}} &{\begin{array}{ll}\stackrel{H}{r} & \infty \\
\stackrel{\vec{\sigma}}{*}= & =\end{array}} &{\text { 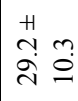 }} &{\begin{array}{l}\stackrel{0}{2} \\
\stackrel{+}{+}\end{array}} &{ } &{\frac{0}{8}} &{\begin{array}{l}\stackrel{0}{n} \\
\dot{\gamma}\end{array}} &{\text { 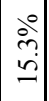 }} &{\begin{array}{l}0 \\
\stackrel{+}{+} \\
\dot{d}\end{array}} &{\begin{array}{c}\dot{0} \\
\dot{i} \\
\infty\end{array}} &{\mid \begin{array}{l}\text { ڤ̊̀ } \\
\vdots \\
0\end{array}} &{\frac{\partial^{\circ}}{\frac{1}{2}}} &{ } &{\begin{array}{l}0 \\
8 \\
\dot{0} \\
\dot{n}\end{array}} &{\begin{array}{l}\stackrel{0}{\circ} \\
\stackrel{0}{0} \\
-1\end{array}} &{\text { 官 }} &{\begin{array}{l}0 \\
\stackrel{0}{+} \\
\text { הे }\end{array}} &{ } &{\text { 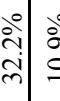 }} &{\text { 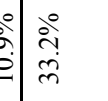 }} &{\stackrel{\stackrel{\circ}{0}}{\circ}} \\
{\hline \begin{array}{l}\text { 今ે } \\
0 \\
0 \\
2\end{array}} &{\begin{array}{l}\infty \\
\infty \\
\infty\end{array}} &{\begin{array}{l}\stackrel{0}{0} \\
\infty \\
\dot{0} \\
+\end{array}} &{\begin{array}{ll}\vec{H} & \\
\stackrel{m}{*} & 0 \\
\vec{\gamma} & \stackrel{]}{\mid}\end{array}} &{\begin{array}{l}H \\
\overrightarrow{2} \\
\overrightarrow{2}\end{array}} &{\begin{array}{l}0 \\
0 \\
0 \\
0\end{array}} &{ } &{\begin{array}{l}\stackrel{0}{0} \\
\stackrel{1}{ } \\
i\end{array}} &{\begin{array}{l}\stackrel{0}{0} \\
\dot{+} \\
\dot{\nabla}\end{array}} &{\mid \begin{array}{c}0 \\
\stackrel{1}{1} \\
\\
-1\end{array}} &{\begin{array}{l}\stackrel{0}{0} \\
\text { ते }\end{array}} &{\begin{array}{l}0 \\
\vdots \\
0\end{array}} &{\mid \begin{array}{l}\stackrel{0}{\grave{2}} \\
\stackrel{2}{-1}\end{array}} &{\text { ஷें }} &{ } &{\begin{array}{l}\stackrel{0}{0} \\
\dot{6}\end{array}} &{\begin{array}{l}\text { ठें } \\
\text { ते }\end{array}} &{\text { ڤัे }} &{\text { 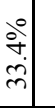 }} &{ } &{\text { 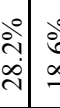 }} &{\begin{array}{c|c}\circ \\
\dot{b} \\
\dot{0} \\
\dot{0} & \stackrel{0}{+} \\
\dot{q}\end{array}} &{\begin{array}{l}\stackrel{0}{i} \\
\text { co }\end{array}} \\
{\hline \frac{N}{U}} &{\widehat{\approx}} &{\begin{array}{l}\stackrel{0}{i} \\
i \\
m\end{array}} &{\text { 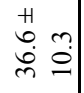 }} &{\begin{array}{l}H \\
\stackrel{+}{J} \\
\stackrel{J}{\sim}\end{array}} &{\text { in }} &{ } &{\begin{array}{l}0 \\
\dot{0} \\
\dot{0} \\
0\end{array}} &{\begin{array}{c}0 \\
0 \\
\infty \\
\infty\end{array}} &{\mid \begin{array}{c|}0^{0} \\
\infty \\
-\infty\end{array}} &{\text { 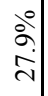 }} &{\begin{array}{l}\stackrel{0}{\stackrel{2}{二}} \\
=\end{array}} &{\left|\begin{array}{c}\stackrel{0}{0} \\
\dot{+} \\
\dot{m}\end{array}\right|} &{\begin{array}{l}\dot{o}^{\circ} \\
\ddot{\infty}\end{array}} &{ } &{\begin{array}{l|l}0 \\
\infty \\
\infty \\
\infty \\
\end{array}} &{\begin{array}{l}\text { ठें } \\
\text { ते }\end{array}} &{\text { 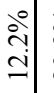 }} &{\text { 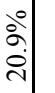 }} &{ } &{\text { 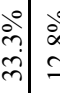 }} &{\text { 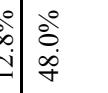 }} &{\stackrel{\stackrel{\circ}{+}}{\stackrel{ \pm}{-}}} \\
{\hline \text { 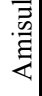 }} &{\begin{array}{l}\infty \\
\text { Nు }\end{array}} &{\begin{array}{l}\stackrel{0}{0} \\
\dot{b} \\
\dot{f}\end{array}} &{\text { 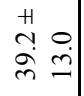 }} &{\begin{array}{l}+ \\
+ \\
\dot{0}\end{array} \stackrel{0}{=}} &{\begin{array}{l}0 \\
\infty \\
\infty \\
\infty\end{array}} &{ } &{\text { 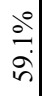 }} &{\text { }} &{\text { 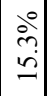 }} &{\begin{array}{l}\stackrel{0}{2} \\
\stackrel{2}{-}\end{array}} &{\text { ڤे̀ }} &{\mid \begin{array}{c}\stackrel{0}{+} \\
\stackrel{+}{-}\end{array}} &{\text { 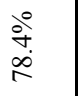 }} &{ } &{\text { 官 }} &{\begin{array}{l}\stackrel{0}{0} \\
0 \\
\dot{q}\end{array}} &{\text { 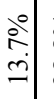 }} &{\begin{array}{c}0 \\
\infty \\
\infty \\
\infty \\
\infty\end{array}} &{ } &{\text { 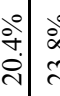 }} &{\begin{array}{l|l}\circ & 0 \\
0 \\
\dot{b} \\
\dot{\nu}\end{array}} &{\frac{0^{\circ}}{6}} \\
{\hline \begin{array}{l}\stackrel{\Xi}{\Xi} \\
\vec{\sigma}\end{array}} &{\text { ঃ }} &{\begin{array}{c}\stackrel{\circ}{+} \\
\dot{+} \\
\dot{f}\end{array}} &{\begin{array}{ll}+ & \\
b & - \\
\dot{q} & \vec{m}\end{array}} &{\text { 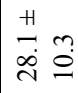 }} &{\text { ڤें }} &{ } &{\text { 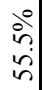 }} &{\begin{array}{c}\stackrel{0}{\circ} \\
\stackrel{\infty}{\infty}\end{array}} &{\left|\begin{array}{l}\text { aे } \\
\text { iे }\end{array}\right|} &{\text { 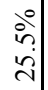 }} &{\mid \begin{array}{l}0 \\
8 \\
0 \\
0\end{array}} &{\left|\begin{array}{l}0 \\
0 \\
0 \\
0 \\
0\end{array}\right|} &{\frac{\stackrel{\circ}{n}}{\infty}} &{ } &{\begin{array}{l}0 \\
i \\
\infty \\
\infty\end{array}} &{\text { 窎 }} &{\text { 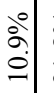 }} &{\begin{array}{l}\text { के } \\
\dot{m} \\
\dot{m}\end{array}} &{ } &{\text { 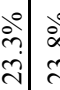 }} &{\text { 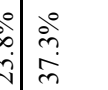 }} &{\text { 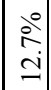 }} \\
{\hline \text { حิ }} &{\stackrel{\infty}{a}} &{\text { 节 }} &{\text { 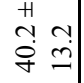 }} &{\text { 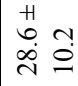 }} &{\stackrel{\circ}{\stackrel{0}{=}}} &{ } &{\begin{array}{l}0 \\
0 \\
0 \\
0 \\
0\end{array}} &{\begin{array}{l}\circ \\
\dot{b} \\
i\end{array}} &{\begin{array}{l}0 \\
\dot{b} \\
= \\
=\end{array}} &{\text { 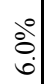 }} &{\left|\begin{array}{l}0 \\
0 \\
0 \\
0 \\
0\end{array}\right|} &{\mid \begin{array}{c}0 \\
2 \\
0 \\
-1\end{array}} &{\stackrel{\stackrel{\circ}{*}}{i}} &{ } &{\text { ২े. }} &{\text { 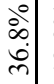 }} &{\text { 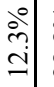 }} &{\begin{array}{c}0 \\
\infty \\
\infty \\
\grave{\nu}\end{array}} &{ } &{\text { ले|lo }} &{\begin{array}{c}0 \\
\text { col } \\
\text { ân }\end{array}} &{\text { 菅. }} \\
{\hline \frac{N}{0}} &{\text { 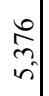 }} &{\begin{array}{l}\stackrel{0}{\circ} \\
\dot{y}\end{array}} &{\text { 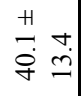 }} &{\stackrel{+}{\dddot{n}=}=} &{\frac{0}{2}} &{ } &{\begin{array}{l}0 \\
\stackrel{0}{+} \\
\dot{0}\end{array}} &{\begin{array}{l}\circ \\
\dot{0} \\
\dot{+}\end{array}} &{\mid \begin{array}{l}\stackrel{0}{0} \\
\dot{+}\end{array}} &{\text { iñ }} &{\mid \begin{array}{c}\stackrel{0}{+} \\
\stackrel{+}{0} \\
\infty\end{array}} &{\mid \begin{array}{l}\mid \\
\text { aे } \\
=\end{array}} &{\text { 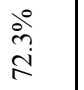 }} &{ } &{\text { 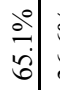 }} &{\text { 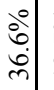 }} &{\text { 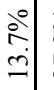 }} &{\text { خें }} &{ } &{\text { 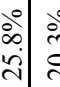 }} &{\text { 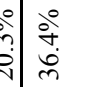 }} &{\stackrel{\infty}{0}^{\circ}} \\
{\hline \begin{array}{l}0 \\
\overline{0} \\
0 \\
0 \\
0 \\
0 \\
0 \\
0 \\
0 \\
0 \\
0 \\
0\end{array}} &{\mathrm{z}} &{\text { 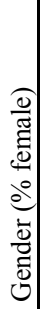 }} &{\text { 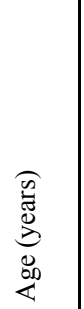 }} &{\text { 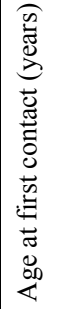 }} &{\text { 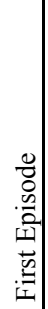 }} &{\text { 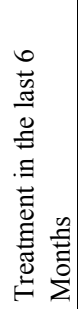 }} &{\text { 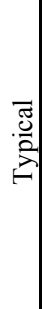 }} &{\begin{array}{l}\stackrel{0}{.} \\
\stackrel{\tilde{N}}{0} \\
\frac{0}{0}\end{array}} &{\text { 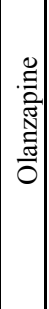 }} &{\text { 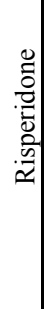 }} &{\text { 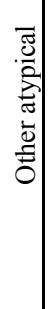 }} &{\text { 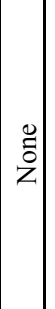 }} &{\text { 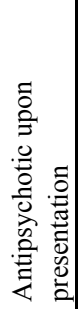 }} &{\text { 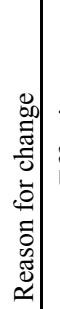 }} &{\text { 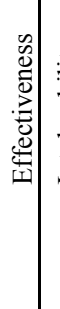 }} &{\text { 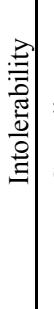 }} &{\text { 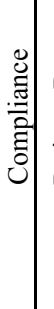 }} &{\text { 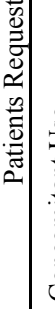 }} &{\text { 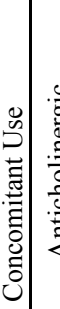 }} &{\text { 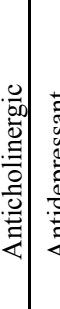 }} &{\text { 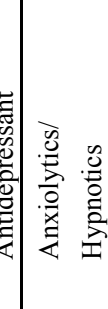 }} &{\text { 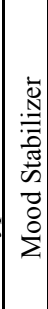 }} \\
$\hline
\end{tabular}




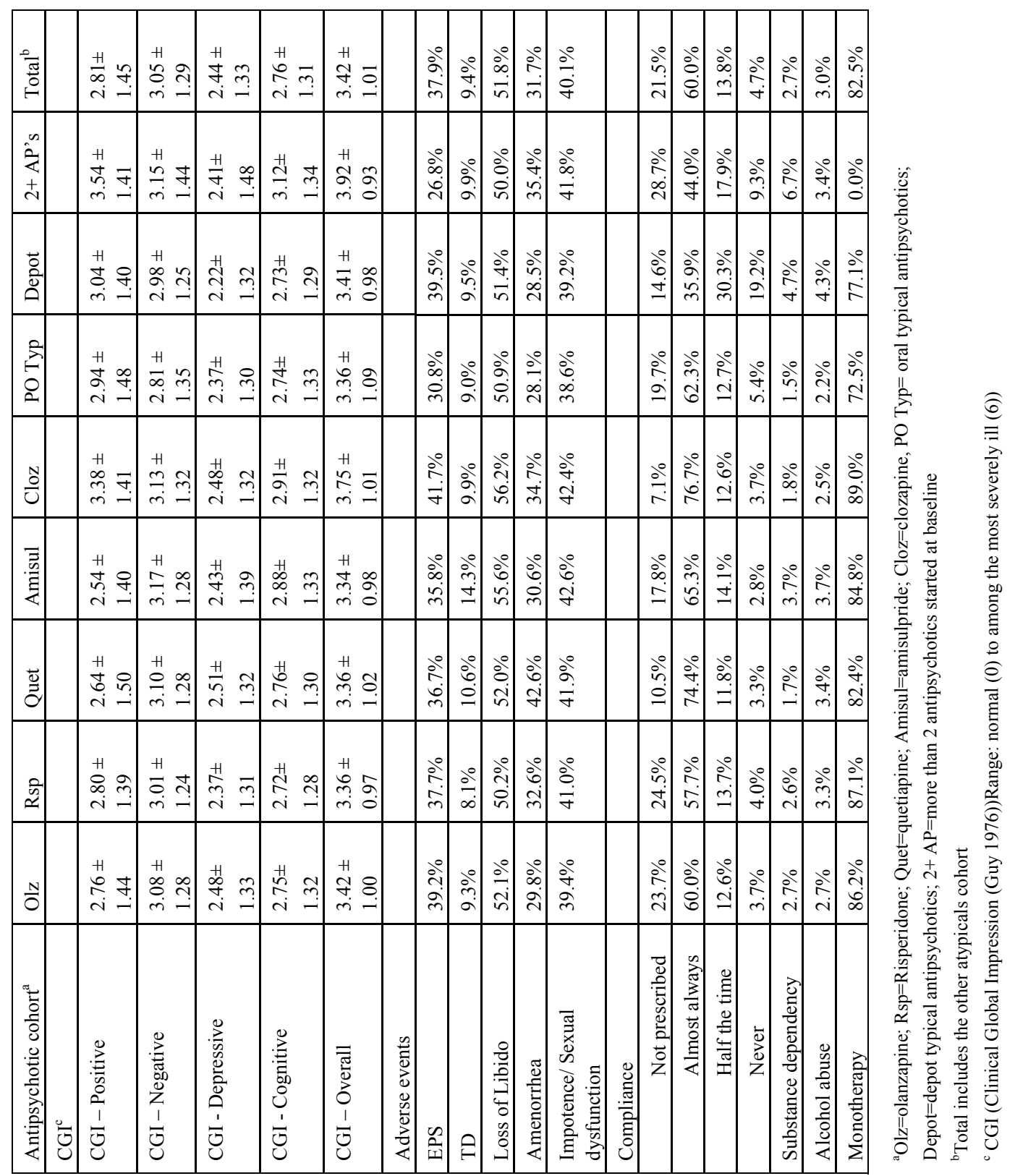


Table 2: Covariates decided upon by the SOHO advisory board

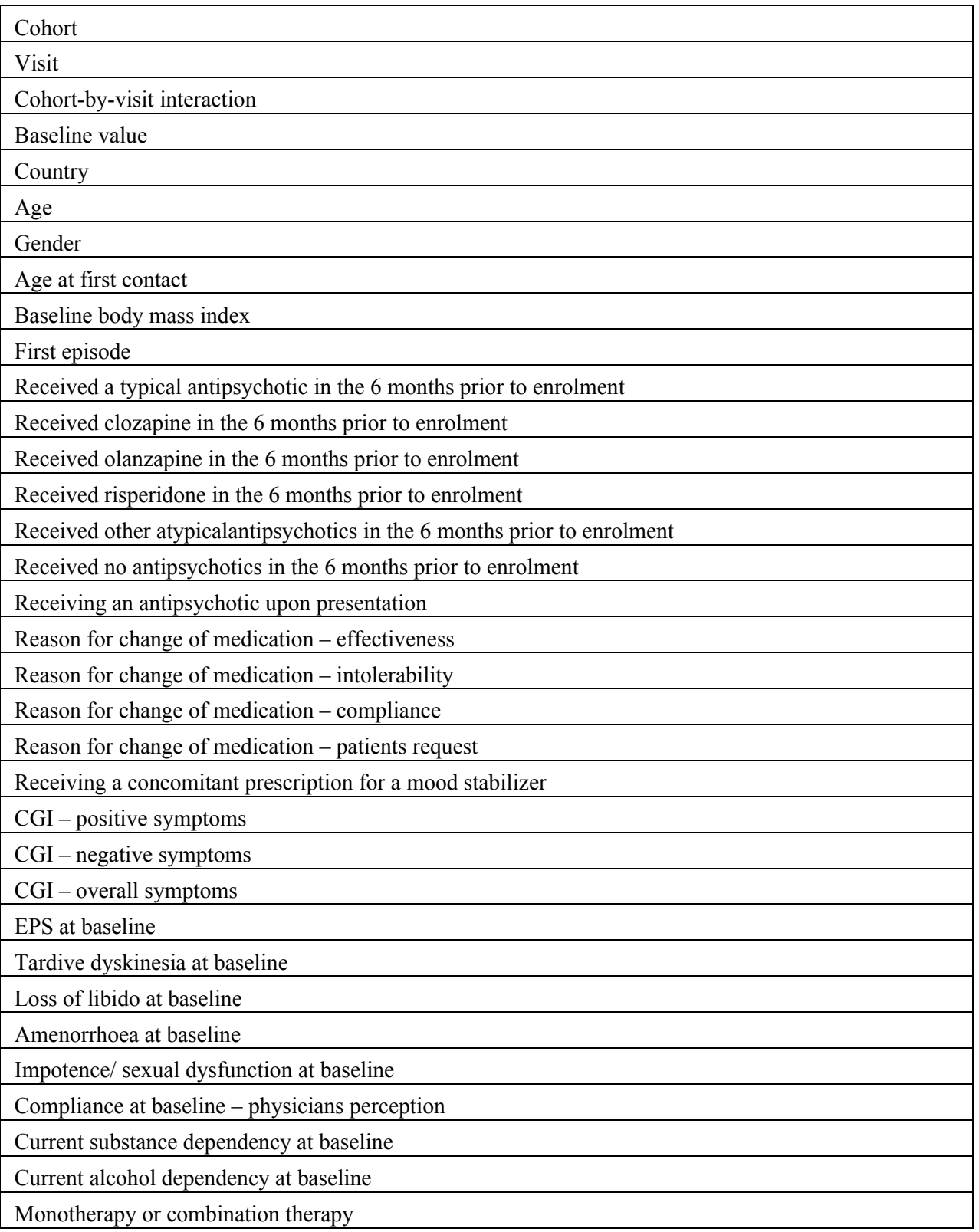




\section{REFERENCES}

Benson, K. and A. J. Hartz (2000). "A comparison of observational studies and randomized, controlled trials." Am J Ophthalmol 130(5): 688.

Concato, J., N. Shah, et al. (2000). "Randomized, controlled trials, observational studies, and the hierarchy of research designs." N Engl J Med 342(25): 1887-92.

Kunz, R. and A. D. Oxman (1998). "The unpredictability paradox: review of empirical comparisons of randomised and non-randomised clinical trials." BMJ 317(7167): 1185-90.

Licht, R. W., G. Gouliaev, et al. (1997). "Generalisability of results from randomised drug trials. A trial on antimanic treatment." Br J Psychiatry 170: 264-7.

MacLehose, R. R., B. C. Reeves, et al. (2000). "A systematic review of comparisons of effect sizes derived from randomised and non-randomised studies." Health Technol Assess 4(34): 1-154.

Pocock, S. J. and D. R. Elbourne (2000). "Randomized trials or observational tribulations?" N Engl J Med 342(25): 1907-9.

Wells, K. B. (1999). "Treatment research at the crossroads: the scientific interface of clinical trials and effectiveness research." Am J Psychiatry 156(1): 5-10. 


\section{CHAPTER 3}

\section{Little Evidence of Risk factors for Onset of Tardive Dyskinesia in Schizophrenia?}




\section{Dear Editors,}

The identification of factors contributing to the susceptibility of tardive dyskinesia (TD) is of crucial importance for the development of preventive strategies.

In order to evaluate true risk factors, studies included must apply some basic epidemiological concepts including: i) obtaining the exposure of interest prospectively in a sample free of the outcome of interest, ii) defining the population and sample it properly and iii) defining the outcome clearly and completely and measure it validly and completely (Kraemer, Kazdin et al. 1997). Many studies of risk factors for TD, however, are either cross-sectional or retrospective and conducted in diagnostically mixed populations. Although cross-sectional studies have their merits for generating hypotheses, their risk estimates are a mixture of effects on onset and persistence (prognosis) and are therefore difficult to interpret, in particular because of the naturally waxing and waning course of TD. Thus, older age may well predispose for onset of TD in a patient without movement disorder, but it may also bias the course more towards persistence instead of the waxing and waning seen in younger individuals, or simply increase the general likelihood of spontaneous dyskinesia as actually observed in older people in the general population in the context of, for example, ill fitting dentures (Blanchet, Abdillahi et al. 2004). The mixture of patients with Alzheimer's disease, schizophrenia and neurological disorder observed in many studies may also introduce further bias because of likely different underlying aetiologies of the movement disorder in these different conditions. Furthermore, because schizophrenia is the only psychiatric disorder where antipsychotic naïve patients in all age categories exhibit signs of TD, a unique, illness-related causal mechanism may apply (Fenton, Blyler et al. 1997; Fenton 2000).

In order to further examine the issue of risk factors for incidence of TD in schizophrenia, a meta-analytic study was undertaken with an exclusive focus on true (i.e. following individuals without TD for prospectively assessed transition to TD) incidence of TD, focussing on samples in which the majority of patients had a diagnosis of schizophrenia.

A Medline search was conducted in December 2005 restricted to truly prospective studies of incident cases of TD. Inclusion criteria were: i) patient populations with at least $80 \%$ patients with schizophrenia, ii) a population at risk of at least 50 subjects (i.e. the minimum sample required to have $80 \%$ power to detect a relative risk of around 3 given a 20\% exposure rate and 20\% rate of TD in the unexposed; two small studies [Waddington, Youssef et al. 1990; McCreadie, Padmavati et al. 2002] were excluded because of this criterion, one of which would have been excluded in any case because data were insufficient), iii) a (prospective) follow-up of subjects at risk. In the case of studies excluded because of heterogeneous patient populations and published later than 1985, the first author was contacted for additional information on the sub-sample of patients with schizophrenia. Furthermore, authors were contacted for missing information where applicable. The risk factor "first generation antipsychotic" versus "second generation antipsychotic" was excluded, as this risk factor has been the subject of a recent, separate and comprehensive metaanalysis (Correll, Leucht et al. 2004). 
Measures of relative risk were collected from the individual studies, either directly or by calculating the relative risk from the cox- or logistic regression coefficient provided in the papers. Both fixed and random effect models were used to calculate an estimate of the combined effect in case of multiple studies using the same measure of risk and outcome.

Only six studies satisfied the inclusion criteria reporting on 22 different single estimate risk factors in a total sample size of 551 subjects, and a mean sample size of 92 subjects (for a full list of excluded studies go to www.TenbackTD.homestead.com). Of the twenty-two risk factors, only six concerned replicated estimates suitable for meta-analysis. Of these six, one risk factor (akathisia) predicted TD in both the fixed and random effects model in schizophrenia, with a further suggestive effect of the risk factor 'being non-white' (table 1). The single estimate risk factors are not considered conclusive evidence because risk factors are rarely defined by a priori definition and therefore are likely to represent type I error in the absence of replication.

It is concluded that despite many reported risk factors for TD in schizophrenia in the literature, little conclusive evidence exists to corroborate this, with the exception of first generation antipsychotics and, possibly, akathisia. 
Table 1. Risk factors for incident TD

\begin{tabular}{|c|c|c|c|c|c|c|}
\hline $\begin{array}{l}\text { Risk } \\
\text { Factor }\end{array}$ & Rating Scale & $\begin{array}{l}\text { RR 95\% CI } \\
\text { Fixed effect }\end{array}$ & Q statistic ${ }^{\mathrm{a}}$ & $\begin{array}{l}\text { RR 95\% CI } \\
\text { Random } \\
\text { effect }\end{array}$ & $\begin{array}{l}\text { Number } \\
\text { of } \\
\text { Subjects }\end{array}$ & References \\
\hline Age & Continuous & $\begin{array}{l}1.02 \\
(0.99,1.06) \\
\mathrm{P}=0.16\end{array}$ & $\begin{array}{l}5.0 ; \mathrm{df}=2 ; \\
\mathrm{P}=0.08\end{array}$ & $\begin{array}{l}1.03 \\
(0.96,1.11) \\
\mathrm{P}=0.39\end{array}$ & 306 & $\begin{array}{l}\text { Chakos } 1996 \\
\text { Oosthuizen, } \\
2003 \\
\text { Chouinard, } 1988\end{array}$ \\
\hline $\begin{array}{l}\text { Female } \\
\text { sex }\end{array}$ & Dichotomous & $\begin{array}{l}0.87 \\
(0.59,1.29) \\
\mathrm{P}=0.50\end{array}$ & $\begin{array}{l}0.56 ; d f=3 ; \\
P=0.90\end{array}$ & $\begin{array}{l}0.87 \\
(0.59,1.29) \\
\mathrm{P}=0.50\end{array}$ & 357 & $\begin{array}{l}\text { Chakos, } 1996 \\
\text { Chouinard, } 1988 \\
\text { Oosthuizen } 2003 \\
\text { Gardos, } 1988 \\
\end{array}$ \\
\hline $\begin{array}{l}\text { Non- } \\
\text { white }\end{array}$ & Dichotomous & $\begin{array}{l}2.51 \\
(0.96,6.59) \\
\mathrm{P}=0.06 \\
\end{array}$ & $\begin{array}{l}0.42 ; d f=1 ; \\
P=0.52\end{array}$ & $\begin{array}{l}2.51 \\
(0.96,6.59) \\
\mathrm{P}=0.06 \\
\end{array}$ & 175 & $\begin{array}{l}\text { Oosthuizen } 2003 \\
\text { Chakos, } 1996\end{array}$ \\
\hline Dose & $\begin{array}{l}\text { Mean dose } \\
\text { CPZ } \\
\text { equivalents }\end{array}$ & $\begin{array}{l}1.00 \\
(1.0,1.01) \\
\mathrm{P}=0.83\end{array}$ & $\begin{array}{l}8.11 ; d f=2 ; \\
P=0.02\end{array}$ & $\begin{array}{l}1.03 \\
(0.96,1.10) \\
\mathrm{P}=0.43\end{array}$ & 253 & $\begin{array}{l}\text { Chakos, } 1996 \\
\text { Sachdev, } 2004 \\
\text { Oosthuizen } 2003\end{array}$ \\
\hline $\begin{array}{l}\text { Akathi } \\
\text { sia }\end{array}$ & Dichotomous & $\begin{array}{l}4.81 \\
(2.0,11.5) \\
\mathrm{P}<0.001\end{array}$ & $\begin{array}{l}0.10 ; d f=1 ; \\
P=0.76\end{array}$ & $\begin{array}{l}4.81 \\
(2.0,11.5) \\
\mathrm{P}<0.001\end{array}$ & 166 & $\begin{array}{l}\text { Barnes, } 1983 \\
\text { Sachdev, } 2004 \\
\text { Oosthuizen } \\
2003^{b}\end{array}$ \\
\hline EPS & $\begin{array}{l}\text { Simpson } \\
\text { Angus }\end{array}$ & $\begin{array}{l}1.28 \\
(1.03,1.59) \\
P=0.03\end{array}$ & $\begin{array}{l}2.97 ; \mathrm{df}=2 ; \\
\mathrm{P}=0.23\end{array}$ & $\begin{array}{l}1.18 \\
(0.78,1.78) \\
\mathrm{P}=0.44\end{array}$ & 253 & $\begin{array}{l}\text { Sachdev, } 2004 \\
\text { Oosthuizen } 2003 \\
\text { Chakos } 1996\end{array}$ \\
\hline
\end{tabular}

a Q-statistic: The null hypothesis states that the studies are homogeneous, if heterogeneity exists a random effect model is recommended.

b Study could not be included; relative risk $=\infty$ 


\section{REFERENCES}

Barnes, T. R., T. Kidger, et al. (1983). "Tardive dyskinesia: a 3-year follow-up study." Psychol Med 13(1): 71-81.

Blanchet, P. J., O. Abdillahi, et al. (2004). "Prevalence of spontaneous oral dyskinesia in the elderly: a reappraisal." Mov Disord 19(8): 892-6.

Chakos, M. H., J. M. Alvir, et al. (1996). "Incidence and correlates of tardive dyskinesia in first episode of schizophrenia." Arch Gen Psychiatry 53(4): 313-9.

Chouinard, G., L. Annable, et al. (1988). "A 5-year prospective longitudinal study of tardive dyskinesia: factors predicting appearance of new cases." J Clin Psychopharmacol 8(4 Suppl): 21S-26S.

Correll, C. U., S. Leucht, et al. (2004). "Lower risk for tardive dyskinesia associated with secondgeneration antipsychotics: a systematic review of 1-year studies." Am J Psychiatry 161(3): 414-25.

Fenton, W. S. (2000). "Prevalence of spontaneous dyskinesia in schizophrenia." J Clin Psychiatry 61 Suppl 4: 10-4.

Fenton, W. S., C. R. Blyler, et al. (1997). "Prevalence of spontaneous dyskinesia in schizophrenic and non-schizophrenic psychiatric patients." Br J Psychiatry 171: 265-8.

Gardos, G., A. Perenyi, et al. (1988). "Seven-year follow-up of tardive dyskinesia in Hungarian outpatients." Neuropsychopharmacology 1(2): 169-72.

Kraemer, H. C., A. E. Kazdin, et al. (1997). "Coming to terms with the terms of risk." Arch Gen Psychiatry 54(4): 337-43.

McCreadie, R. G., R. Padmavati, et al. (2002). "Spontaneous dyskinesia and parkinsonism in never-medicated, chronically ill patients with schizophrenia: 18-month follow-up." British Journal of Psychiatry. 181: 135-7.

Oosthuizen, P. P., R. A. Emsley, et al. (2003). "Incidence of tardive dyskinesia in first-episode psychosis patients treated with low-dose haloperidol." J Clin Psychiatry 64(9): 1075-80.

Sachdev, P. (2004). "Early extrapyramidal side-effects as risk factors for later tardive dyskinesia: a prospective study." Aust N Z J Psychiatry 38(6): 445-9.

Waddington, J. L., H. A. Youssef, et al. (1990). "Cognitive dysfunction in schizophrenia followed up over 5 years, and its longitudinal relationship to the emergence of tardive dyskinesia." Psychol Med 20(4): 835-42. 


\section{CHAPTER 4}

Effects of Antipsychotic Treatment on

Tardive Dyskinesia: A 6-Months

Evaluation of Patients From the European Schizophrenia Outpatient Health Outcomes (SOHO) Study

Diederik Tenback, Peter. van Harten, Cees Slooff, Mark Belger, Jim van Os and the SOHO Study Group

J Clin Psychiatry. 2005 Sep;66(9):1130-3. 


\begin{abstract}
:
Objective:To compare the incidence and persistence of tardive dyskinesia between patients diagnosed with schizophrenia (ICD-10 and/ or DSM-IV) who were treated with second-generation antipsychotics and first generation antipsychotics in routine clinical practice.
\end{abstract}

Methods: The European Schizophrenia Outpatient Health Outcomes (SOHO) study is a 3-year, prospective, observational study. Each country had a start date for patient enrollment before October 2000. All enrollment was completed by June 30, 2001. A simple, global measure of tardive dyskinesia was rated by participating clinicians. For the current analysis, data at baseline, 3 months and 6 months were analyzed using a generalized estimating equation model.

Results: Second-generation antipsychotics conferred a lower risk for 6-month tardive dyskinesia than first-generation antipsychotics $(0.9 \%$ vs. $3.8 \%$, OR $=0.29$, $95 \% \mathrm{CI}=0.18-0.46)$. In addition, patients with tardive dyskinesia at baseline on second-generation antipsychotics were less likely to have tardive dyskinesia symptoms at 6 months $(43.6 \%$ vs. $60.8 \%, \mathrm{OR}=0.50,95 \% \mathrm{CI}=0.30-0.85)$. A sensitivity analysis suggested no bias related to pharmaceutical industry financial support.

Conclusion: The results suggest that the relative advantage of second-generation antipsychotics in terms of lower rates of incidence and persistence of tardive dyskinesia, observed in technical randomized controlled trials, generalizes to routine clinical care. 


\section{INTRODUCTION}

Antipsychotic treatment is a major risk factor for tardive dyskinesia (van Os, Fahy et al. 1997; Correll, Leucht et al. 2004). In the course of antipsychotic treatment for patients with a first episode of schizophrenia, about $18 \%$ develop tardive dyskinesia after 4 years (Chakos, Alvir et al. 1996). A prevalence of tardive dyskinesia of up to $58 \%$ in outpatients with schizophrenia has been reported (Chouinard, Annable et al. 1988).

The second-generation antipsychotics are described as "atypical" because of a hypothesized lesser propensity to cause extrapyramidal symptomatology (EPS), including tardive dyskinesia, compared with first generation antipsychotics (Geddes, Freemantle et al. 2000; Correll, Leucht et al. 2004). Several studies focusing on tardive dyskinesia reported a lower rate of treatment-emergent tardive dyskinesia in patients treated with second-generation antipsychotics in comparison with patients treated with first-generation antipsychotics (Beasley, Dellva et al. 1999; Kane 2001). Recent meta-analytic work summarizing effect sizes from studies that primarily included randomized controlled trials (RCTs) confirms that secondgeneration antipsychotics as a group confer a lower risk for tardive dyskinesia than do first-generation antipsychotics (Correll, Leucht et al. 2004). However, to what degree such findings from technical efficacy RCTs that include selected patient populations and have very high attrition rates can be generalized to routine clinical practice remains unknown. The aim of the current study, therefore, was to examine, in routine clinical practice, the rate of emergence and persistence of tardive dyskinesia, and the effects of second-generation antipsychotics and first-generation antipsychotics on these rates. To this end, we used data from the European Schizophrenia Outpatient Health Outcomes (SOHO) study, a large observational study conducted in 10 European countries. Since the study was pharmaceutical industry sponsored, a sensitivity analysis was conducted to examine possible observer bias.

\section{METHOD}

\section{Design and Patients}

The SOHO study is an ongoing, 3-year, prospective, observational health outcome study of the treatment of schizophrenia in Europe. The study is being conducted currently in 10 European countries (Denmark, France, Germany, Greece, Ireland, Italy, the Netherlands, Portugal, Spain and the United Kingdom). Each country had a start date for patient enrolment before October 2000. All enrolment was completed by June, 30, 2001.Enrolment followed a nonrandomized process to provide 2 patient cohorts of approximately equal size: patients with schizophrenia defined according to ICD-10 and/or DSM-IV who initiated or changed to treatment with olanzapine or an antipsychotic other than olanzapine. Patients were enrolled after a treatment decision was made independent from participation in the study. Entry 
criteria were (i) initiating or changing antipsychotic medication for the treatment of schizophrenia and (ii) presenting within the normal course of care in the outpatient setting.

Patients were included regardless of whether the new antipsychotic drug was substituted for a previous medication or was an addition to existing treatment. Data were collected using a data collection form with a selection of measures that considered simplicity and ease of use with no training requirement. Investigators assessed the tardive dyskinesia and EPS (acute dystonia/akathisia/parkinsonism) that they judged to be associated with antipsychotic drug treatment. Tardive dyskinesia and EPS were rated on a four-point scale: $1=$ not present, $2=$ present but does not significantly interfere with patient's functioning or health-related quality of life, $3=$ present and significantly interferes with patient's functioning or health-related quality of life, and $4=$ present and interference with functioning outweighs therapeutic effect. For the purpose of the current analyses, the variable was treated as dichotomous (present (2,3 and 4) vs. not present (1)). Incidence refers to tardive dyskinesia not present at baseline and scored present at the 3- or 6- month follow up, and persistence refers to tardive dyskinesia scored present at baseline and at the 3- and 6months follow up.

Alcohol and/or substance dependence or abuse was rated dichotomously if the investigator judged patients to suffer from diagnosable alcohol and/or substance dependency or abuse. Full details of the SOHO study design have been published previously (Haro, Edgell et al. 2003).

Ethics Committee approval and informed consent was obtained as required by national regulations.

\section{Data Analysis}

To assess outcomes associated with second generation or first generation antipsychotics in actual practice, treatment cohorts were defined according to the class of antipsychotic initiated at the baseline assessment. Each individual had 3 observations: baseline, 3- and 6-month follow-up. The proportion of patients at the 6-month visit who remained on their initial antipsychotic without adding any additional antipsychotics, remained on their initial antipsychotic and had an additional antipsychotic added, and switched antipsychotics were summarized by cohort. Patients for whom a new antipsychotic was initiated without discontinuation of their existing antipsychotic were assigned to the cohort corresponding to the class of the newly initiated antipsychotic.

A generalized estimating equation model with a logit link and a repeatedmeasurements approach was used to model the data. The unstructured covariance matrix was used in the analysis. Prognostic covariates were agreed upon by the SOHO advisory board and included in the model. Covariates included baseline age, sex, length of illness, prior- (and type of) antipsychotic, mono- or combination antipsychotic therapy, reasons for change of antipsychotic, alcohol abuse and EPS. (A full list is available on request.) Pairwise comparisons of the first-generation antipsychotic cohort with the second-generation antipsychotic cohort at the 6-month visit using the cohort-by-visit interaction term were calculated. Odds ratios (ORs) and 
95\% confidence intervals (CIs) are reported for each of these comparisons. Approximately $80 \%$ of the sample was included in the model, due to missing values in the covariates.

A sensitivity analysis was conducted by examining effect sizes of secondgeneration antipsychotics excluding individuals who were initiated on treatment with olanzapine.

\section{RESULTS}

A total of 10,972 patients were enrolled in the SOHO study, of whom 9912 were considered in the analysis of tardive dyskinesia at baseline. Approximately $9 \%$ $(\mathrm{N}=912)$ were diagnosed with existing tardive dyskinesia. Of the 9912 patients with tardive dyskinesia data at baseline, 8632 patients were eligible for analysis at 6 months ( a total of 8774 patients had data at 6 months, but data on tardive dyskinesia were missing for 142 of these patients). This sample of 8632 constituted the final risk set in which all analyses were conducted.

\section{Baseline Patient Characteristics}

Despite the absence of randomization in the study, there were only few differences between the treatment cohorts in any of the baseline demographic characteristics as shown in Table 1 . The sample mean age was $40.1(\mathrm{SD}=13.1), 42.2 \%$ of the patients were female. With respect to baseline severity of schizophrenia, the overall mean score on the Clinical Global Impression score(Guy 1976) was $3.42(\mathrm{SD}=1.01)$, between mildly and moderately ill. In the last 6 months prior to the study enrollment, roughly two thirds of patients received first-generation antipsychotics (61.7\%), while $41.8 \%$ received second-generation antipsychotics and $15.9 \%$ had no antipsychotic treatment. Reasons for change of antipsychotic treatment (not mutually exclusive) were lack of effectiveness $(63.6 \%)$, intolerability (34.6\%), noncompliance $(15.2 \%)$, and patient request $(28.4 \%)$. A relatively large proportion of patients (37.9\%) experienced EPS at baseline.

\section{Six-Months Follow-up.}

Attrition at 6 months was low: $88.5 \%$ of baseline patients (8774/9912) were interviewed at 6 months. Most patients $(83 \%)$ remained on the antipsychotic treatment that was initiated at baseline. Of these, $65 \%$ received monotherapy (Table 2).

The rate of emerging tardive dyskinesia was higher in the first-generation antipsychotic than the second-generation antipsychotic group: 3.8 vs. $0.9 \%$ (OR: $0.29,95 \%$ CI: 0.18 to 0.46 ). Similarly, persistence of tardive dyskinesia was more frequent in the first-generation antipsychotics than the second-generation antipsychotics cohort: 60.8 vs. $43.6 \%$ (OR: $0.50,95 \%$ CI: 0.30 to 0.85 ). 


\section{Sensitivity Analyses}

Excluding patients treated with olanzapine at the 6-month visit yielded a somewhat attenuated but essentially similar pattern of results. The incidence of tardive dyskinesia for first-generation antipsychotic versus second-generation antipsychotic was 3.8 versus $1.4 \%$ (OR: $0.43,95 \%$ CI: 0.25 to 0.72 ). Persistence of tardive dyskinesia for first-generation antipsychotics versus second-generation antipsychotics was 60.8 versus $46.7 \%$ (OR: $0.60,95 \% \mathrm{CI}$ : 0.33 to 1.11 ).

\section{DiscUSSION}

\section{Findings}

Treatment with second-generation antipsychotic was associated with a lower incidence and a lower persistence of tardive dyskinesia compared to treatment with first-generation antipsychotics. A sensitivity analysis excluding the product of the sponsor (olanzapine) yielded slightly reduced and statistically somewhat more imprecise effect sizes, but overall the pattern of the findings was similar. The results concur with those from RCTs(Correll, Leucht et al. 2004), and generalize to routine clinical practice. Furthermore, in patients with existing tardive dyskinesia, treatment with second-generation antipsychotics is more effective than treatment with firstgeneration antipsychotics with respect to clinical improvement. No RCT data or conclusive evidence are available for second-generation antipsychotics on reduction of existing tardive dyskinesia (Soares and McGrath 1999). However, a number of smaller studies and case reports are suggestive for an effect of second-generation antipsychotics on reduction of existing tardive dyskinesia (Llorca, Chereau et al. 2002). The current report, however, has a number of advantages over prior work, including presence of a control group, longer duration of treatment, and sufficient statistical power.

\section{Methodological Issues}

The results should be interpreted in the context of several methodological limitations. The measure for tardive dyskinesia used is likely to cause underreporting. Weiden et al,(Weiden, Mann et al. 1987) compared clinicians' with clinical researchers' recognition of the major extrapyramidal syndromes with clinical researchers using standardized ratings; the major finding was a high rate of clinical underrecognition of all major extrapyramidal syndromes, especially tardive dyskinesia. In the current study, the patients presented themselves fully dressed in regular outpatient settings where a more formal physical examination may not be standard. Moreover, treatment was defined by cohorts according to the class of antipsychotic initiated at the baseline assessment. The results presented here should be attributed 
to these cohorts as opposed to the subsequent effects that may have resulted from changes in medication regimens after baseline for individual patients.

Although sponsored observational trials are potentially subject to bias, the results suggest that the comparison between first-generation antipsychotics and secondgeneration antipsychotics, which in the context of this trial arguably may not be biased, is in favour of the second-generation antipsychotic in terms of 6-month risk of tardive dyskinesia. The position of second-generation antipsychotics as a treatment for existing tardive dyskinesia requires further investigation; however in the absence of other safe and effective therapies, the data suggest that secondgeneration antipsychotics may be useful. 
Table 1: Baseline Demographics by Cohort for Patients With Schizophrenia Receiving FirstGeneration or Second-Generation Antipsychotics

\begin{tabular}{|c|c|c|c|}
\hline \multirow[b]{3}{*}{ Variable } & \multicolumn{2}{|c|}{ Second-Generation Antipsychotic } & \multirow{3}{*}{$\begin{array}{l}\text { First Generation } \\
\text { Antipsychotic }\end{array}$} \\
\hline & Any & Non-Olanzapine & \\
\hline & & & \\
\hline Patients, $\mathrm{N}$ & 8,739 & 3,363 & 1,173 \\
\hline Female, $\%$ & 41.7 & 42.6 & 45.8 \\
\hline Age, mean $\pm \mathrm{SD}, \mathrm{y}$ & $40.0 \pm 13.2$ & $39.9 \pm 13.0$ & $41.5 \pm 12.3$ \\
\hline Age at first contact, mean $\pm \mathrm{SD}, \mathrm{y}$ & $28.9 \pm 10.8$ & $28.2 \pm 10.2$ & $29.1 \pm 10.2$ \\
\hline First Episode of Schizophrenia, \% & 10.8 & 8.6 & 5.8 \\
\hline Antipsychotic upon presentation, $\%{ }^{a}$ & 74.2 & 77.2 & 76.6 \\
\hline Extrapyramidal symptoms, \% & 38.6 & 37.7 & 34.4 \\
\hline \multicolumn{4}{|l|}{ Tardive dyskinesia scale rating $\%,{ }^{b}$} \\
\hline 1 & 90.6 & 90.5 & 90.8 \\
\hline 2 & 7.5 & 7.8 & 7.7 \\
\hline 3 & 1.6 & 1.3 & 1.4 \\
\hline 4 & 0.3 & 0.4 & 0.1 \\
\hline Total with tardive dyskinesia present & 9.4 & 9.5 & 9.2 \\
\hline Substance dependence, $\%$ & $2.6 \%$ & $2.4 \%$ & $2.8 \%$ \\
\hline Alcohol abuse, $\%$ & $2.9 \%$ & $3.3 \%$ & $3.1 \%$ \\
\hline
\end{tabular}

aPercentage of patients who received antipsychotic treatment during the 6 months prior to study enrolment.

bThe tardive dyskinesia scale was scored as follows: $1=$ not present, $2=$ present but does not significantly interfere with patient's functioning or health-related quality of life, $3=$ present and significantly interferes with patient's functioning or health-related quality of life, $4=$ present and interference with functioning outweighs therapeutic effect. 
Table 2. Treatment Patterns at 6 Months After Baselinea

\begin{tabular}{|c|c|c|c|c|c|c|c|c|}
\hline \multirow[b]{2}{*}{ Variable $\%{ }^{\mathrm{a}}$} & \multicolumn{5}{|c|}{ Second-Generation Antipschotics } & \multicolumn{2}{|c|}{$\begin{array}{l}\text { First-Generation } \\
\text { Antipsychotics }\end{array}$} & \multirow[b]{2}{*}{$2+\mathrm{AP}^{\mathrm{b}}$} \\
\hline & $\begin{array}{l}\text { Olan- } \\
\text { zapine }\end{array}$ & $\begin{array}{l}\text { Ris- } \\
\text { peridone }\end{array}$ & $\begin{array}{l}\text { Que- } \\
\text { tiapine }\end{array}$ & $\begin{array}{l}\text { Ami- } \\
\text { sulpride }\end{array}$ & Clozapine & Per os & Depot & \\
\hline $\mathrm{N}$ at baseline & 5,376 & 1,918 & 790 & 328 & 327 & 688 & 485 & 268 \\
\hline $\mathrm{N}$ at 6 months & 4,716 & 1,711 & 690 & 282 & 301 & 625 & 449 & 233 \\
\hline $\begin{array}{l}\% \text { with } 6 \\
\text { month data }\end{array}$ & 87.7 & 89.2 & 87.3 & 86.0 & 92.0 & 90.8 & 92.6 & 86.9 \\
\hline $\begin{array}{l}\text { Mono- } \\
\text { therapy after } \\
\text { baseline visit }\end{array}$ & 86.2 & 87.1 & 82.4 & 84.8 & 89.0 & 72.5 & 77.1 & - \\
\hline $\begin{array}{l}\text { Still on drug } \\
\text { initiated at } \\
\text { baseline at } 6 \\
\text { months }\end{array}$ & 89.1 & 84.4 & 75.2 & 77.6 & 87.4 & 75.5 & 80.8 & - \\
\hline $\begin{array}{l}\text { Mono- } \\
\text { therapy at the } \\
\text { six month visit }\end{array}$ & 71.8 & 68.0 & 53.3 & 58.9 & 74.4 & 50.6 & 56.3 & - \\
\hline $\begin{array}{l}\text { Any } \\
\text { concomitant } \\
\text { medication use } \\
\text { at six months }\end{array}$ & 47.9 & 62.8 & 56.5 & 44.6 & 58.8 & 60.7 & 53.1 & 62.2 \\
\hline $\begin{array}{l}\text { Anticho- } \\
\text { linergic use at } \\
6 \text { months }\end{array}$ & 8.7 & 23.6 & 12.5 & 12.1 & 10.0 & 26.0 & 29.0 & 25.3 \\
\hline $\begin{array}{l}\text { Antidepres- } \\
\text { sant use at } 6 \\
\text { months }\end{array}$ & 19.5 & 20.7 & 22.5 & 21.8 & 20.9 & 17.9 & 12.5 & 19.3 \\
\hline $\begin{array}{l}\text { Anxiolitic } \\
\text { /hypnotic use } \\
\text { at } 6 \text { months }\end{array}$ & 28.9 & 37.2 & 35.5 & 21.8 & 34.6 & 36.9 & 27.2 & 32.2 \\
\hline $\begin{array}{l}\text { Mood } \\
\text { stabilizer use } \\
\text { at } 6 \text { months }\end{array}$ & 9.7 & 9.8 & 12.5 & 8.2 & 17.9 & 12.3 & 7.6 & 14.2 \\
\hline
\end{tabular}

a Values are percentages unless otherwise noted.

b More than 1 antipsychotic started at baseline 


\section{REFERENCES:}

Beasley, C. M., M. A. Dellva, et al. (1999). "Randomised double-blind comparison of the incidence of tardive dyskinesia in patients with schizophrenia during long-term treatment with olanzapine or haloperidol." Br J Psychiatry 174: 23-30.

Chakos, M. H., J. M. Alvir, et al. (1996). "Incidence and correlates of tardive dyskinesia in first episode of schizophrenia." Arch Gen Psychiatry 53(4): 313-9.

Chouinard, G., L. Annable, et al. (1988). "A 5-year prospective longitudinal study of tardive dyskinesia: factors predicting appearance of new cases." J Clin Psychopharmacol 8(4 Suppl): 21S-26S.

Correll, C. U., S. Leucht, et al. (2004). "Lower risk for tardive dyskinesia associated with secondgeneration antipsychotics: a systematic review of 1-year studies." Am J Psychiatry 161(3): 414-25.

Geddes, J., N. Freemantle, et al. (2000). "Atypical antipsychotics in the treatment of schizophrenia: systematic overview and meta-regression analysis." Bmj 321(7273): 1371-6.

Guy, W. (1976). ECDEU Assessment Manual for Psychopharmacology, revised, Rockville, MD: U.S. Department of Health and Human Service, Alcohol Drug Abuse and Mental Health Administration, NIMH Psychopharmacology Research Branch.: 218-222.

Haro, J. M., E. T. Edgell, et al. (2003). "The European Schizophrenia Outpatient Health Outcomes (SOHO) study: rationale, methods and recruitment." Acta Psychiatr Scand 107(3): 222-32.

Kane, J. M. (2001). "Extrapyramidal side effects are unacceptable." Eur Neuropsychopharmacol 11 Suppl 4: S397-403.

Llorca, P. M., I. Chereau, et al. (2002). "Tardive dyskinesias and antipsychotics: a review." Eur Psychiatry 17(3): 129-38.

Soares, K. V. and J. J. McGrath (1999). "The treatment of tardive dyskinesia--a systematic review and meta-analysis." Schizophr Res 39(1): 1-16; discussion 17-8.

van Os, J., T. Fahy, et al. (1997). "Tardive dyskinesia: who is at risk?" Acta Psychiatr Scand 96(3): 206-16.

Weiden, P. J., J. J. Mann, et al. (1987). "Clinical nonrecognition of neuroleptic-induced movement disorders: a cautionary study." Am J Psychiatry 144(9): 1148-53. 


\section{CHAPTER 5}

Evidence That Early Extrapyramidal Symptoms Predict Later Tardive Dyskinesia: A Prospective Analysis of 10,000 Patients in the European Schizophrenia Outpatient Health Outcome (SOHO) Study 


\begin{abstract}
:
Objective: This study examined whether early extrapyramidal symptoms predict 1year incidence of tardive dyskinesia.

Method: Simple, global measures were used to rate extrapyramidal symptoms and tardive dyskinesia in a prospective, observational health outcomes study. Baseline and 3-, 6-, and 12-month data on 9,298 patients were analyzed by using a Cox proportional-hazard model. Onset of tardive dyskinesia was examined in two groups: 1) no tardive dyskinesia at baseline (broad risk set) and 2) no tardive dyskinesia at baseline and 3 months (narrow risk set).

Results: The risk of tardive dyskinesia was twice as high in patients in the broad risk set who had baseline extrapyramidal symptoms than in patients without them; it was also elevated in the narrow risk set. In the adjusted analyses, this effect size was not reduced.
\end{abstract}

Conclusions: Tardive dyskinesia may be linked with early extrapyramidal symptoms, providing opportunities for risk reduction in the population exposed to antipsychotics. 


\section{INTRODUCTION}

Research suggests that antipsychotic-induced extrapyramidal symptoms, such as parkinsonism, dystonia, and akathisia, increase the risk for tardive dyskinesia in elderly patients (Saltz, Woerner et al. 1991; Jeste, Caligiuri et al. 1995; Woerner, Alvir et al. 1998).

However, only scant (Chouinard, Annable et al. 1986) and sometimes conflicting (Oosthuizen, Emsley et al. 2003)evidence exists that younger patients exposed to antipsychotics are similarly at risk. Indirect evidence exists, however, as metaanalyses noted a lower risk of extrapyramidal symptoms (Geddes, Freemantle et al. 2000)and lower risk of tardive dyskinesia (Correll, Leucht et al. 2004)in patients treated with second-generation antipsychotics.

We used prospective data from a large cohort of patients treated in routine clinical settings to 1) calculate incidence rates of tardive dyskinesia and 2) examine early extrapyramidal symptoms as a predictor of tardive dyskinesia incidence.

\section{METHOD}

The Schizophrenia Outpatient Health Outcomes (SOHO) study is a 3-year prospective, observational health outcome study of the treatment of schizophrenia in Europe. Data were collected with a selection of measures that were simple and easy to use with no required training. Investigators assessed the tardive dyskinesia and extrapyramidal symptoms (defined as dystonia, akathisia, or parkinsonism) that they observed during treatment with antipsychotic medication. Tardive dyskinesia and extrapyramidal symptoms were separately rated on a 4-point scale: $1=$ not present, $2=$ present but does not significantly interfere with patient's functioning or health-related quality of life, $3=$ present and significantly interferes with patient's functioning or health-related quality of life, and 4=present and outweighs therapeutic effect. Full details of the study design have been published previously(Haro, Edgell et al. 2003). Ethics committee approval and informed consent were obtained as required by national regulations.

Each individual had four observations: baseline and 3-, 6-, and 12-month follow-up. For the purposes of these analyses, extrapyramidal symptoms and tardive dyskinesia were treated as dichotomous outcomes; present was defined as a score of 2,3, or 4 , and not present was defined as a score of 1 . In order to take into account the waxing and waning course of tardive dyskinesia, a sensitivity analysis approach was used with two different risk sets: one including all individuals with no tardive dyskinesia at baseline (broad risk set) and one including participants with no tardive dyskinesia at baseline and no tardive dyskinesia at 3 months (narrow risk set).

In order to calculate the incidence rates of tardive dyskinesia, three time bands were 
constructed: baseline to 3 months, 3 to 6 months, and 6 to 12 months. Each person was allocated person-time according to the interval from baseline to the visit in which the patient was diagnosed with tardive dyskinesia or, if no such diagnosis was made, to the last visit. Incidence rates for each time band were calculated by dividing the number of incident cases by the person-years. The total incidence of tardive dyskinesia was calculated by dividing the total number of incident cases of tardive dyskinesia by the total person-years.

To assess extrapyramidal symptoms as a risk factor for tardive dyskinesia, Cox proportional-hazard regression analysis was used. Prognostic covariates were those agreed on by the study's advisory board, and additional confounders were included as guided by previous literature (Kane, Woerner et al. 1988; Jeste, Caligiuri et al. 1995). Thus, apart from the predictor variable (extrapyramidal symptoms at baseline), the covariates included treatment with second- or first-generation antipsychotics (pre- and postbaseline); scores on the Clinical Global Impression positive, negative, cognitive, and depressive items at baseline; sex and age at baseline and their interaction term; age at first contact; and first episode status (the full list of covariates is available on request). Approximately $80 \%$ of the sample was included in the model with all covariates, and the remainder were excluded because of missing values for the covariates.

Associations between extrapyramidal symptoms and tardive dyskinesia were expressed as hazard ratios, together with their 95\% confidence intervals (CIs). Sensitivity and specificity values for baseline extrapyramidal symptoms were also calculated as a "test" for follow-up tardive dyskinesia. All analyses used the Stata program (StataCorp).

\section{RESULTS}

A total of 9,298 patients had data for baseline extrapyramidal symptoms and for tardive dyskinesia at baseline and 3-month follow-up; 8,036 patients had data on tardive dyskinesia at all four measurement occasions. In the group of 9,298 patients, the prevalence rates of tardive dyskinesia and extrapyramidal symptoms at baseline were $9.2 \%$ and $37.8 \%$, respectively. The mean age was 40.1 years $(\mathrm{SD}=13.1)$, and $57.6 \%$ of the patients were men, $9.8 \%$ were experiencing their first episode, and $37.6 \%$ had been exposed to a second-generation antipsychotic in the 6 months before enrollment; this proportion rose to $85.8 \%$ after baseline.

The total incidence for tardive dyskinesia was 3.0\% $(95 \% \mathrm{CI}=2.6 \%-3.4 \%)$ in the broad risk set and $1.6 \%(95 \% \mathrm{CI}=1.4 \%-1.9 \%)$ in the narrow risk set. In the unadjusted analyses, baseline extrapyramidal symptoms predicted tardive dyskinesia (broad risk set: hazard ratio $=2.0,95 \% \mathrm{CI}=1.6-2.6$; narrow risk set: hazard ratio $=1.6,95 \% \mathrm{CI}=1.1-2.3$ ). In the adjusted analyses, this effect size was not reduced (broad risk set: hazard ratio $=2.3,95 \% \mathrm{CI}=1.6-3.2$; narrow risk set: hazard ratio $=2.1,95 \% \mathrm{CI}=1.3-3.3$ ).

The sensitivity of baseline extrapyramidal symptoms as a test for follow-up tardive 
dyskinesia was around 50\% (broad risk set: 53\%; narrow risk set: $46 \%$ ). The specificity for both broad and narrow tardive dyskinesia was $67 \%$.

\section{DISCUSSION}

Extrapyramidal symptoms predicted onset of tardive dyskinesia, suggesting important clinical implications. The validity of the finding, however, hinges on the validity of the clinical ratings of extrapyramidal symptoms and tardive dyskinesia. The measures used are simple; the assessment of extrapyramidal symptoms does not differentiate among akathisia, dystonia, and parkinsonism, nor does it give strict criteria for how to diagnose these syndromes. It could be argued that clinicians' assessments of extrapyramidal symptoms at baseline represent misclassification of tardive dyskinesia, because clinicians cannot distinguish between extrapyramidal symptoms and tardive dyskinesia. Although this cannot be excluded, and a degree of misclassification may have occurred, it could have explained the results only if clinicians had been misclassifying extrapyramidal symptoms and tardive dyskinesia inconsistently. This is unlikely to have been the case, as clinicians do not change randomly in their concepts of what constitutes the clinical presence of extrapyramidal symptoms and tardive dyskinesia. Furthermore, the most common form of extrapyramidal symptoms is parkinsonism, and it is unlikely that clinicians fail to differentiate between the hypokinetic syndrome parkinsonism and the hyperkinetic syndrome tardive dyskinesia. Akathisia, however, albeit less prevalent than parkinsonism, can more easily be mistaken for tardive dyskinesia.

Previous conflicting results in patients with first-episode schizophrenia could be due to limited statistical power (Oosthuizen, Emsley et al. 2003), and our results concur with most previous work suggesting that extrapyramidal symptoms are a risk factor for tardive dyskinesia (Chouinard, Annable et al. 1986; Saltz, Woerner et al. 1991; Jeste, Caligiuri et al. 1995; Woerner, Alvir et al. 1998). Given the fact that the sensitivity and specificity of baseline extrapyramidal symptoms as a test for later tardive dyskinesia were too low to justify a high-risk prevention strategy (i.e., targeting individuals with existing extrapyramidal symptoms to prevent tardive dyskinesia), the clinical implication of the findings is, instead, that a population strategy aimed at reducing the risk factor of extrapyramidal symptoms in the whole population of patients using antipsychotics is most likely to effectively reduce the morbidity force of tardive abnormal movements related to early extrapyramidal side effects. 


\section{REFERENCES}

Chouinard, G., L. Annable, et al. (1986). "A five year follow-up study of tardive dyskinesia." Psychopharmacol Bull 22(1): 259-63.

Correll, C. U., S. Leucht, et al. (2004). "Lower risk for tardive dyskinesia associated with secondgeneration antipsychotics: a systematic review of 1-year studies." Am J Psychiatry 161(3): 414-25.

Geddes, J., N. Freemantle, et al. (2000). "Atypical antipsychotics in the treatment of schizophrenia: systematic overview and meta-regression analysis." BMJ 321(7273): 1371-6.

Haro, J. M., E. T. Edgell, et al. (2003). "The European Schizophrenia Outpatient Health Outcomes (SOHO) study: rationale, methods and recruitment." Acta Psychiatrica Scandinavica. 107(3): 222-32.

Jeste, D. V., M. P. Caligiuri, et al. (1995). "Risk of tardive dyskinesia in older patients. A prospective longitudinal study of 266 outpatients." Arch Gen Psychiatry 52(9): 756-65.

Kane, J. M., M. Woerner, et al. (1988). "Tardive dyskinesia: prevalence, incidence, and risk factors." J Clin Psychopharmacol 8(4 Suppl): 52S-56S.

Oosthuizen, P. P., R. A. Emsley, et al. (2003). "Incidence of tardive dyskinesia in first-episode psychosis patients treated with low-dose haloperidol." Journal of Clinical Psychiatry. 64(9): 1075-80.

Saltz, B. L., M. G. Woerner, et al. (1991). "Prospective study of tardive dyskinesia incidence in the elderly." Jama 266(17): 2402-6.

StataCorp "(2002): STATA Statisctical Software: Release 8.0. Texas: College Station."

Woerner, M. G., J. M. Alvir, et al. (1998). "Prospective study of tardive dyskinesia in the elderly: rates and risk factors." American Journal of Psychiatry. 155(11): 1521-8. 


\section{CHAPTER 6}

\section{Tardive Dyskinesia in Schizophrenia is Associated with Prolactin-Related Sexual Disturbances}




\begin{abstract}
:
Introduction:Tardive dyskinesia (TD) may occur in never-medicated patients with psychotic illness, indicating the existence of non-medication, possibly diseaserelated, causes. We tested the hypothesis that, independent of the antipsychoticinduced rise in prolactin, the incidence of TD would be associated with the incidence of prolactin-related sexual disturbances (PRSD), which would be suggestive of a common pathology involving multiple dopamine tracts.
\end{abstract}

Methods:Simple, global measures of TD and PRSD (loss of libido, amenorrhea, gynaecomastia, impotence, and galactorrhea) were rated in a prospective, observational European Health Outcomes Study (SOHO). New onset of TD and new onset of PRSD at 3, 6, and 12 months was analyzed in a risk set of 4263 patients using a Cox proportional hazard model yielding adjusted hazard ratios (aHR).

Results: Incidence of TD was significantly and linearly comorbid with the incidence of PRSD in both men and women. Compared to those with no PRSD, the risk for TD was 2.0 (95\% CI: 1.1, 3.7) with one PRSD, $2.4(95 \%$ CI: 1.3, 4.5) with two PRSD, and 3.6 (95\% CI: 1.1, 11.8) with three PRSD. Associations were stronger in those who only had received prolactin-sparing medications (aHR per unit PRSD increase $=2.0,95 \%$ CI: $1.2,3.3)$ than in those who only had received prolactinraising medications $(\mathrm{aHR}=1.3,95 \% \mathrm{CI}: 0.9,1.9)$.

Conclusion: In people with schizophrenia, TD and PRSD show comorbidities that are independent of antipsychotic induced alterations in plasma prolactin. This may suggest a shared, pandopaminergic pathological mechanism associated with schizophrenia itself, rather than only a medication effect. 


\section{INTRODUCTION}

Only a minority of patients with a diagnosis of schizophrenia develop tardive dyskinesia (TD) over the course of antipsychotic treatment, indicating that some individuals carry a particular vulnerability to this condition. Although treatmentemergent TD has been reported in patients taking antipsychotic medications, the condition also occurs in patients not exposed to antipsychotic medication (Fenton, Wyatt et al. 1994). Therefore, some of the causes contributing to the risk of TD are thought to be intrinsic to the disease itself, possibly in interaction with age-related changes in the dopamine system (van Os, Fahy et al. 1997).

Although the nigrostriatal pathway is central in theories on the causes of TD, any hypothesized pathophysiological mechanisms may well extend to other dopamine tracts. If this were true, the rate of TD should be associated with indicators of dysfunction of other dopamine tracts, suggesting that TD is only one indicator of a much more widespread, pandopaminergic dysfunctional state. The tuberoinfundibular dopamine pathway regulates, by inhibition, pituitary prolactin secretion, causing sexual adverse events such as loss of libido, amenorrhea, gynaecomastia, impotence, and galactorrhea (Halbreich, Kinon et al. 2003; Knegtering, van der Moolen et al. 2003; Haddad and Wieck 2004). There is some evidence that TD is associated with a deviant neuroendocrine response following prolactin challenge (Csernansky, Prosser et al. 1986; Monteleone, Maj et al. 1988). However, not all the evidence is conclusive. Some authors reported differential prolactin responses in women but not in men (Glazer, Moore et al. 1981), whereas others found no dissimilarities in prolactin response between patients with and without TD (Asnis, Sachar et al. 1979; Jeste, Neckers et al. 1981; Tripodianakis, Markianos et al. 1983). As the above experimental studies may be sampling around small effect sizes producing inconsistent results, a complementary epidemiological approach, focusing on prospective associations between evidence of abnormalities of the tuberoinfundibular pathway and onset of TD in large samples, may be productive. While it is difficult to obtain plasma prolactin in large epidemiological studies, sexual disturbance may serve as an indirect measure. Although the sexual disturbances seen in schizophrenia are of multifactorial origin, and therefore only in part attributable to illness-related or medication-related prolactin levels (Halbreich, Kinon et al. 2003; Knegtering, van der Moolen et al. 2003; Haddad and Wieck 2004), they may nevertheless serve as an indirect measure for prolactin elevation in epidemiological studies, in particular if numerous confounding variables can be adequately controlled for. In the current paper prospective data from a large cohort of patients treated in routine clinical settings was used to examine the incident comorbidities of prolactin-related sexual disturbances (PRSD) and TD, applying analytical methods for complete adjustment of multiple confounding factors. As any association between PRSD and TD may be caused by their joint dependency on antipsychotic medication, analyses were stratified depending on whether the prescribed antipsychotic was prolactin-sparing or prolactin-raising. We hypothesized that if the asso- 
ciation between PRSD and TD were medication-induced, this should be more apparent in the group exposed to prolactin-raising medications and higher levels of PRSD. If, however, observed comorbidity between PRSD and TD were intrinsic to the psychotic illness itself, associations should be equally or more evident in the group prescribed prolactin-sparing medications with lower levels of PRSD.

\section{METHODS}

\section{Design and Patients}

The SOHO study is an ongoing, 3-year prospective, observational health outcome study of the treatment of schizophrenia in Europe. Data was collected using a data collection form with a selection of measures that considered simplicity and ease of use with no training requirement.

Investigators assessed the TD and PRSD that they judged to be associated with antipsychotic drug treatment. The basis for both ratings was clinical judgment. TD was rated on a four-point scale: (1) not present, (2) present, but does not significantly interfere with patient's functioning or health-related quality of life, (3) present, and significantly interferes with patient's functioning or health-related quality of life, (4) present, and outweighs therapeutic effect.

Full details of the SOHO study design have been published previously (Haro, Edgell et al. 2003). Ethics Committee approval and informed consent was obtained as required by national regulations.

\section{PRSD and Validation of Association with Prolactin}

Loss of libido, amenorrhea or other menstrual disturbance, gynaecomastia, galactorrhea, and impotence or sexual dysfunction were rated on the basis of clinical judgment on a three point scale: (1) not present, (2) present, (3) not applicable. In order to validate their hypothesized association with prolactin, a variable was constructed dividing patients into two groups: those prescribed prolactin-raising medications (all first-generation oral and depot antipsychotics[FGA], risperidone, and amisulpiride) after each of the four visits over the 12-month period, and patients prescribed prolactin-sparing medications (all second generation antipsychotics [SGA] except risperidone and amisulpiride) after each of the four visits over the 12month period (Knegtering, van der Moolen et al. 2003; Haddad and Wieck 2004). Associations between PRSD and the variable reflecting prolactin-raising or prolactin-sparing group (hereafter: antipsychotic-induced prolactin) were examined in order to test whether PRSD would be higher in those exposed to prolactin-raising medication. 


\section{Antipsychotic Medication and the Association between PRSD and TD}

As any association between PRSD and TD may be caused by their joint dependency on antipsychotic medication as explained earlier, associations between PRSD and TD were examined for moderation by type of medication, again using the 'antipsychotic-induced prolactin' variable reflecting prescription of prolactin-sparing or prolactin-raising antipsychotics.

\section{Data Analysis}

Each individual had four observations: baseline, 3, 6, and 12-month follow-up. For the purpose of the analyses, TD and PRSD were treated as dichotomous outcomes as follows: TD: present $=$ score 2,3 or 4 vs not present=score 1; PRSD: present $=$ score 2 vs not present $=$ score 1 and 3 . The 'not applicable' ratings for the PRSD were recoded 'not present' because the majority of subjects with a rating of 'not applicable' had been taking medication and therefore were per definition at risk of developing PRSD. The only item truly considered 'not applicable' was amenorrhea in men. PRSD was also expressed as a sum score indicating the number of $\operatorname{PRSD}(0,1,2,3$ or more).

In order to calculate the incidence rates of TD and PRSD, three time bands were constructed (baseline-3 months, 3-6 months, and 6-12 months). Each person was allocated person-time according to the interval from baseline to the visit in which a patient was diagnosed with TD or, if no such diagnosis was made, to the last visit. Incidence rates for each time band were calculated by dividing the number of incident cases by the total person-years. The total incidence of TD or PRSD was calculated by dividing the total number of incident cases of TD or PRSD by the total person-years.

In order to assess the degree of comorbidity between TD and PRSD, associations between 12-month incidence of TD and 12-month incidence of PRSD were calculated in a risk set free of TD and PRSD at baseline, using a Cox proportional hazard survival regression model of survival time without TD with PRSD as a timevarying covariate.

\section{Adjustment by Propensity Score}

Covariates were those agreed upon by the SOHO advisory board and included sex, age, age of first contact, body mass index, first episode status, compliance, and country among others (full list of covariates available on request). In addition, guided by previous literature, the following time-varying variables measured at the time of TD and PRSD assessments at 3, 6, and 12 months were included (Lieberman, Alvir et al. 1994; Yuen, Caligiuri et al. 1996; Caligiuri, Lacro et al. 1997; Halbreich, Kinon et al. 2003; Correll, Leucht et al. 2004): treatment with SGA or FGA (pre- and post-assessment occasion), Clinical Global Impression positive, negative, cognitive, and depressive symptoms, other medications such as antidepressants, anticholinergics, and mood stabilizers. Approximately $80 \%$ of the sample was included in the model with all covariates, due to missing values in the covari- 
ates. As there were many confounding variables included in the models, traditional control for confounding by inclusion of covariates in the model may not be sufficient, as the degree of 'control' afforded by such models depends on the overlap in characteristics between the two outcome groups. The use of the propensity score has been suggested as a means to obtain more complete control (Rubin 1997; Joffe and Rosenbaum 1999) in these circumstances. A 'propensity score' is a modelbased predicted probability of being exposed (in this case, of being in the group with sexual side effects). Predictors in the model are all of the potential confounding variables (ie characteristics on which the groups differ). Instead of controlling for a long list of confounders, the propensity score itself is controlled for, thus effectively controlling for all of the covariates included in the propensity models, and minimizing the loss of degrees of freedom in controlling for confounders.

Associations between PRSD and TD were expressed as incidence rate ratios and Cox proportional hazard ratios (unadjusted: HR; adjusted: aHR), together with their $95 \%$ confidence intervals. Interactions with sex and the antipsychotic-induced prolactin variable were assessed by Wald test (Clayton and Hills 1993). Reported probability values for the predictor variable reflect two-sided tests of the null hypothesis of no association. All analyses were performed using the computer package STATA, version 9.1(StataCorp. 2005).

\section{RESULTS}

\section{BaselineCharacteristics}

A total of 9645 patients had non-missing data for PRSD and TD at baseline. The prevalence of TD in these 9645 was 898 (9.3\%), and the prevalence of any PRSD was 5139 (53.3\%); loss of libido: $45.6 \%$; impotence or sexual dysfunction: $33.5 \%$, gynaecomastia: $3.1 \%$, galactorrhea $2.0 \%$; amenorrhea in women: $25.6 \%$. The risk set of patients without TD and without PRSD at baseline consisted of 4263 individuals. The mean age of these 4263 was 38.8 years $(\mathrm{SD}=13.5), 58.9 \%$ were men, $16.4 \%$ were first episode and 34.4\% had been exposed to an SGA in the 6 months before enrolment. After the baseline assessment, the proportion exposed to SGA rose to $85.0 \%$. The number of individuals in the risk set prescribed prolactin-raising medication at all visits post-baseline was $1216(40 \%)$, and the number prescribed prolactin-sparing medications at all visits post-baseline was $1812(60 \%)$.

\section{PRSD and Validation of Association with Prolactin}

Over the follow-up period, there were 1162 incident cases of PRSD (loss of libido: 936; impotence or sexual dysfunction: 612; gynaecomastia: 60; galactorrhea: 41; amenorrhea in women: 198). Of the 1162 patients presenting with incident PRSD, 784 had one, 519 had two, and 68 had three PRSD. The incidence of PRSD was $37.0 \%(95 \% \mathrm{CI}: 34.9,39.2)$, and higher in the group prescribed only prolactin- 
raising medications (43\%, 95\% CI: 39-48) than in the group prescribed only prolactin-sparing medications (32\%, 95\% CI: 29-35; $\mathrm{P}<0.001)$.

\section{Incidence of TD}

Over the follow-up period, there were 95 incident cases of TD, yielding a TD incidence rate of $2.6 \%(95 \% \mathrm{CI}: 2.1,3.2)$. The TD incidence was significantly comorbid with PRSD, independent of a range of confounders (Table 1). The sum scores of incident PRSD and TD were associated with each other in a dose-response fashion: compared to those with no PRSD $(\mathrm{HR}=1)$, those with $1 \mathrm{PRSD}(\mathrm{aHR}=2.0,95 \% \mathrm{CI}$ : 1.1, 3.7, $\mathrm{P}=0.024$ ), 2 PRSD (adjusted $\mathrm{HR}=2.4,95 \% \mathrm{CI}: 1.3,4.5, \mathrm{P}=0.008$ ) and 3 PRSD (adjusted HR=3.6, 95\% CI: 1.1, 11.8, $\mathrm{P}=0.036$ ) were at progressively higher risk of developing TD (summary aHR linear trend: 1.6, 95\% CI: 1.2, 2.0, $\mathrm{P}=0.001$ ). There were no interactions with sex (any PRSD excluding amenorrhea: $\chi 2=2.59$, $\mathrm{P}=0.11)$.

\section{Incidence of TD and Antipsychotic-induced Prolactin}

All the effect sizes of the association between PRSD and TD were larger in the group of individuals prescribed only prolactin-sparing medications, although formal comparisons between the two effects sizes remained statistically inconclusive by conventional alpha (Table 2).

\section{DISCUSSION}

A significant association was found between TD and sexual disturbances in patients with schizophrenia: the minority of individuals, who were at risk of developing TD, also displayed an elevated risk of developing PRSD.

In interpreting the results, it was assumed that loss of libido, impotence or sexual dysfunction, gynaecomastia, galactorrhea, and amenorrhea in women were prolactin-related to at least a degree. This, however, may be questioned, as many factors apart from prolactin may impact on these variables. For example, dopamine itself plays a role in general arousal (Paredes and Agmo 2004) and antipsychotic-induced histaminergic, noradrenergic, alpha-blocking, and anticholinergic effects, as well as the effects of concomitant medication, all potentially influence sexual behaviour (Knegtering, van der Moolen et al. 2003). Nevertheless, the validity of our exposure, in terms of it reflecting prolactin activity, is supported by (i) the simple and basic observation that patients reporting sexual dysfunctions on average have higher serum prolactin levels (Knegtering 1999), and (ii) the fact that the current analyses did indeed confirm that PRSD were more common among those prescribed prolactin-raising medications. Furthermore, treatment-emergent sexual adverse events have been reported during treatment with antipsychotics known to elevate prolactin levels relatively specifically, suggesting prolactin may be related to the incidence of 
sexual dysfunction with a relatively small additional role suggested for histaminergic, noradrenergic, serotonergic, and cholinergic mechanisms (Knegtering, van der Moolen et al. 2003). In addition, gynaecomastia, galactorrhea, and amenorrhea are among the clinical presentations more specifically associated with hyperprolactinaemia (Luciano 1999; Haddad and Wieck 2004).

Assuming that all PRSD variables are prolactin-related to a degree, arguably the simplest explanatory factor that can be evoked is that both PRSD and TD are caused by prolactin elevation induced by antipsychotic medications (Knegtering, van der Moolen et al. 2003; Haddad and Wieck 2004). However, this is unlikely as the association between TD and PRSD was, if anything, stronger rather than weaker for prolactin-sparing medications with a lower risk for both PRSD (Knegtering, van der Moolen et al. 2003; Haddad and Wieck 2004) and TD (Correll, Leucht et al. 2004).

Therefore, although antipsychotic medication may well contribute separately to the onset of both TD and PRSD, the fact that survival without TD was at best only weakly associated with newly arising PRSD in those exposed to prolactin-raising medications suggests that the rise in prolactin, occasioned by antipsychotic medications, is not the common mechanism causing TD and PRSD to cluster over time. This is not unexpected, given the fact that the rise in prolactin is related to interactions between antipsychotic medication and D2 receptors that are outside the bloodbrain barrier (Kapur, Langlois et al. 2002; Knegtering, Baselmans et al. 2005), whereas the onset of TD is likely to reflect the central effects of antipsychotic medication. In other words, prolactin-raising medications may contribute separately to the risk of both TD and PRSD in the long term, but if the mechanisms and 'incubation' periods for these two outcomes are different, they will not be associated in time-to-event analyses as presented here. In contrast, their simultaneous clustering over time in those exposed to prolactin-sparing medications suggests an underlying common and central vulnerability, involving more than one central dopamine tract, that may be intrinsic to schizophrenia itself, and only detectable in the absence of external agents causing substantial increases in plasma prolactin that overshadow this internal, illness-related, association. Indeed, a recent investigation reported pituitary enlargement in never-medicated patients with schizophrenia, compatible with the hypothesis of a central, illness-related, mechanism (Pariante, Dazzan et al. 2005). Similarly, a recent report found high prolactin levels in a paranoid subgroup of never-medicated psychotic patients, suggestive of the existence of subtypes of psychotic illness associated with differences in dopaminergic tone (Segal, Avital et al. 2004). Another possible explanation may reside in differential D2 sensitivity in groups with and without TD (Shim, Kim et al. 2005). However, none of the above research findings provides a direct explanation for the association between PRSD and TD. Two basic, nonexclusive, types of explanations are possible. The first is that the same cause contributes to the onset of two conditions with different underlying pathologies. For example, stress is the most prevalent systemic condition associated with hyperprolactinaemia (Halbreich, Kinon et al. 2003), and may be associated with TD through a mechanism involving raised cortisol levels (Aleem, Kulkarni et al. 1988) or a mechanism involving modulation of the dopamine receptor by estrogen and its diverse and complex influences on prolactin levels (Turrone, Seeman et al. 2000; Halbreich, Kinon et al. 2003). The second explanation is that 
the same underlying pathology can be expressed pleiotropically as both TD and sexual disturbances, as both have been observed to be more prevalent in unmedicated patients with schizophrenia (Gregory 1957; Fenton, Wyatt et al. 1994; Aizenberg, Zemishlany et al. 1995), possibly indicative of a pandopaminergic dysfunction related to schizophrenia itself. Although it is not possible to distinguish between the two models on the basis of the current data, the latter explanation is the most parsimonious.

The results should be interpreted in the light of several methodological limitations. Our data derives from an observational study in which the investigator 'observes and evaluates results of ongoing medical care without 'controlling' the therapy beyond normal medical practice.' Controlling the therapy beyond normal medical practice also applies to the measures used to evaluate the pathology of interest or invasive procedures like blood monitoring (CPMP 1996). By implication, this means that the current study relied on PRSD as a derived measure for prolactin. Many underlying causes may contribute to hyperprolactinaemia such as, for example, systemic conditions (eg cirrhosis, chronic renal failure or meningiomas) and non-psychotropic medications acting on the CNS (eg verapamil, estrogens, and other substances (Halbreich, Kinon et al. 2003). However, the prevalence of these alternative causes are probably very low in our sample, and unlikely to have affected the current analysis in a non-random way. Similarly, sexual functioning is influenced by many factors other than hyperprolactinaemia such as demographic factors (Nazareth, Boynton et al. 2003) and chronic medical conditions like hypertension and diabetes (Guay, Velasquez et al. 1999).

Therefore, it is possible that, instead of prolactin, some of these other complex and interacting factors actually drive variation of sexual functioning and are associated with the incidence of $\mathrm{TD}$, in spite of the extensive list of covariates used in the analyses. 
Table 1. Associations between incident of TD and incident of PRSD

\begin{tabular}{|c|c|c|c|c|c|c|c|c|c|c|}
\hline \multirow[t]{2}{*}{ Type of PRSD } & \multicolumn{3}{|c|}{ TD rate with PRSD $^{b}$} & \multicolumn{3}{|c|}{$\begin{array}{l}\text { TD rate without } \\
\text { PRSD }\end{array}$} & \multirow{2}{*}{$\begin{array}{l}\mathrm{HR}^{\mathrm{c}} \\
\text { unadjusted } \\
(95 \% \mathrm{CI})\end{array}$} & \multirow[t]{2}{*}{$P$} & \multirow{2}{*}{$\begin{array}{l}\text { HR } \\
\text { adjusted }^{\text {d }} \\
(95 \% \mathrm{CI})\end{array}$} & \multirow[t]{2}{*}{$\mathrm{P}$} \\
\hline & $\mathrm{n}$ & $\begin{array}{l}\text { person- } \\
\text { years }\end{array}$ & $\begin{array}{l}\text { Rate } \\
(\%)\end{array}$ & $\mathrm{n}$ & $\begin{array}{l}\text { person- } \\
\text { years }\end{array}$ & $\begin{array}{l}\text { Rate } \\
(\%)\end{array}$ & & & & \\
\hline Amenorrhea $^{\mathrm{a}}$ & 2 & 102 & 2.0 & 39 & 1387 & 2.8 & $\begin{array}{l}0.7 \\
(0.2,3.0)\end{array}$ & 0.64 & $\begin{array}{l}0.8 \\
(0.2-3.3)\end{array}$ & 0.73 \\
\hline Galactorrhea & 1 & 18 & 5.5 & 91 & 3607 & 2.5 & $\begin{array}{l}1.9 \\
(0.3-13.8)\end{array}$ & 0.52 & e & \\
\hline Impotence & 23 & 341 & 6.8 & 71 & 3288 & 2.2 & $\begin{array}{l}3.0 \\
(1.9-4.8)\end{array}$ & 0.000 & $\begin{array}{l}2.3 \\
(1.3-4.0) \\
\end{array}$ & 0.003 \\
\hline Loss of libido & 31 & 521 & 6.0 & 63 & 3115 & 2.0 & $\begin{array}{l}2.9 \\
(1.9-4.4)\end{array}$ & 0.000 & $\begin{array}{l}2.4 \\
(1.5-3.9)\end{array}$ & 0.000 \\
\hline Gynaecomastia & 3 & 30 & 10.0 & 91 & 3584 & 2.5 & $\begin{array}{l}3.0 \\
(0.9-9.7)\end{array}$ & 0.06 & $\begin{array}{l}3.2 \\
(1.0-10.6)\end{array}$ & 0.06 \\
\hline $\begin{array}{l}\text { Any Prolactin } \\
\text { side effect }\end{array}$ & 36 & 671 & 5.4 & 59 & 2999 & 2.0 & $\begin{array}{l}2.6 \\
(1.7-4.0) \\
\end{array}$ & 0.000 & $\begin{array}{l}2.2 \\
(1.4-3.6)\end{array}$ & 0.001 \\
\hline
\end{tabular}

${ }^{\mathrm{a}}$ women only

${ }^{\mathrm{b}}$ for example first row: there were 198 women with incident amenorrhea. These 198 contributed 102 personyears follow-up time, whereas 2 developed TD. The rate therefore was $2 \%$. Similarly, 1605 women without amenorrhea contributed 1387 person years, in which 39 developed TD, yielding a rate of $2.8 \%$.

${ }^{\mathrm{c}}$ Hazard ratio, a measure of relative risk

${ }^{\mathrm{d}}$ adjusted for covariated agreed upon by the SOHO advisory board

${ }^{\mathrm{e}}$ model would not converge / unstable estimate due to small numbers 
Table 2. Associations between incidence of TD and incidence of PRSD as a function of antipsychotic-induced prolactin

\begin{tabular}{|l|l|l|l|l|l|l|}
\hline Type of PRSD & $\begin{array}{l}\text { HR }^{\mathrm{b}} \text { prolactin- } \\
\text { raising } \\
(95 \% \mathrm{CI})\end{array}$ & $\mathrm{P}$ & $\begin{array}{l}\mathrm{HR}^{\mathrm{b}} \text { prolactin- } \\
\text { sparing } \\
(95 \% \mathrm{CI})\end{array}$ & $\mathrm{P}$ & \multicolumn{2}{|l|}{ Interaction $^{\mathrm{c}}$} \\
\hline & & & & \multicolumn{2}{|c|}{} \\
\hline Amenorrhea $^{\mathrm{a}}$ & $0.5(0.1,3.5)$ & 0.46 & $2.9(0.4,23.4)$ & 0.32 & 1.51 & 0.21 \\
\hline Galactorrhea $^{\mathrm{d}}$ & & $\mathrm{d}$ & & & \\
\hline Impotence & $1.4(0.6-3.2)$ & 0.46 & $3.6(1.2-10.3)$ & 0.02 & 1.98 & 0.16 \\
\hline Loss of libido & $2.0(1.0-4.0)$ & 0.05 & $2.3(0.8-6.6)$ & 0.12 & 0.05 & 0.82 \\
\hline Gynaecomastia & $2.3(0.5-10.6)$ & 0.27 & $10.9(1.4-82.3)$ & 0.02 & 1.39 & 0.24 \\
\hline $\begin{array}{l}\text { Any Prolactin side } \\
\text { effect }\end{array}$ & $1.9(1.0-3.7)$ & 0.07 & $2.3(0.8-6.2)$ & 0.11 & 0.11 & 0.74 \\
\hline $\begin{array}{l}\text { Continuous Prolactin } \\
\text { score }\end{array}$ & $1.3(0.9-1.9)$ & 0.15 & $2.0(1.2-3.3)$ & 0.01 & 1.76 & 0.18 \\
\hline
\end{tabular}

${ }^{a}$ women only

${ }^{\mathrm{b}}$ Hazard ratio, a measure of relative risk

${ }^{\mathrm{c}}$ tests whether HR in the prolactin-raising group is significantly different from the HR in the prolactinsparing group

${ }^{\mathrm{d}}$ model would not converge / unstable estimate due to small numbers

${ }^{\mathrm{e}}$ number of PRSD $(0,1,2,3$ or more). 


\section{REFERENCES}

Aizenberg, D., Z. Zemishlany, et al. (1995). "Sexual dysfunction in male schizophrenic patients." J Clin Psychiatry 56(4): 137-41.

Aleem, A., A. Kulkarni, et al. (1988). "Dexamethasone suppression test, schizophrenia and movement disorder." Acta Psychiatr Scand 78(6): 689-94.

Asnis, G. M., E. J. Sachar, et al. (1979). "Normal prolactin responses in tardive dyskinesia." Psychopharmacology (Berl) 66(3): 247-50.

Caligiuri, M. P., J. P. Lacro, et al. (1997). "Incidence and risk factors for severe tardive dyskinesia in older patients." Br J Psychiatry 171: 148-53.

Clayton, D. and M. Hills (1993). Statistical Models in Epidemiology. Oxford, Oxford Science Publications.

Correll, C. U., S. Leucht, et al. (2004). "Lower risk for tardive dyskinesia associated with secondgeneration antipsychotics: a systematic review of 1-year studies." Am J Psychiatry 161(3): 414-25.

CPMP (1996). ICH Topic E 6 Guideline for Good Clinical Practice, EMEA.

Csernansky, J. G., E. Prosser, et al. (1986). "Possible associations among plasma prolactin levels, tardive dyskinesia, and paranoia in treated male schizophrenics." Biol Psychiatry 21(7): 63242.

Fenton, W. S., R. J. Wyatt, et al. (1994). "Risk factors for spontaneous dyskinesia in schizophrenia." Arch Gen Psychiatry 51(8): 643-50.

Glazer, W. M., D. C. Moore, et al. (1981). "Serum prolactin and tardive dyskinesia." Am J Psychiatry 138(11): 1493-6.

Gregory, B. A. (1957). "The menstrual cycle and its disorders in psychiatric patients. I. Review of the literature." J Psychosom Res 2(1): 61-79.

Guay, M. F. A., M. E. Velasquez, et al. (1999). "Characterization of patients in a medical endocrine-based center for male sexual dysfunction." Endocr Pract 5(6): 314-21.

Haddad, P. M. and A. Wieck (2004). "Antipsychotic-induced hyperprolactinaemia: mechanisms, clinical features and management." Drugs 64(20): 2291-314.

Halbreich, U., B. J. Kinon, et al. (2003). "Elevated prolactin levels in patients with schizophrenia: mechanisms and related adverse effects." Psychoneuroendocrinology 28 Suppl 1: 53-67.

Haro, J. M., E. T. Edgell, et al. (2003). "The European Schizophrenia Outpatient Health Outcomes (SOHO) study: rationale, methods and recruitment." Acta Psychiatr Scand 107(3): 222-32.

Jeste, D. V., L. M. Neckers, et al. (1981). "Lymphocyte monoamine oxidase and plasma prolactin and growth hormone in tardive dyskinesia." J Clin Psychiatry 42(2): 75-7.

Joffe, M. M. and P. R. Rosenbaum (1999). "Invited commentary: propensity scores." Am J Epidemiol 150(4): 327-33.

Kapur, S., X. Langlois, et al. (2002). "The differential effects of atypical antipsychotics on prolactin elevation are explained by their differential blood-brain disposition: a pharmacological analysis in rats." Journal of Pharmacology \& Experimental Therapeutics 302(3): 1129-34.

Knegtering, H., Blijd, C., Boks, M.P.M (1999). "Sexual dysfunctions and prolactin levels in patients using classical antipsychotics, risperidone or olanzapine." Schizophrenia Research 36(1-3): 355-356.

Knegtering, H., A. E. van der Moolen, et al. (2003). "What are the effects of antipsychotics on sexual dysfunctions and endocrine functioning?" Psychoneuroendocrinology 28 Suppl 2: $109-23$. 
Knegtering, R., P. Baselmans, et al. (2005). "Predominant role of the 9-hydroxy metabolite of risperidone in elevating blood prolactin levels." Am J Psychiatry 162(5): 1010-2.

Lieberman, J. A., J. Alvir, et al. (1994). "Methylphenidate response, psychopathology and tardive dyskinesia as predictors of relapse in schizophrenia." Neuropsychopharmacology 11(2): 107-18.

Luciano, A. A. (1999). "Clinical presentation of hyperprolactinemia." J Reprod Med 44(12 Suppl): 1085-90.

Monteleone, P., M. Maj, et al. (1988). "Prolactin response to sodium valproate in schizophrenics with and without tardive dyskinesia." Psychopharmacology (Berl) 96(2): 223-6.

Nazareth, I., P. Boynton, et al. (2003). "Problems with sexual function in people attending London general practitioners: cross sectional study." Bmj 327(7412): 423.

Paredes, R. G. and A. Agmo (2004). "Has dopamine a physiological role in the control of sexual behavior? A critical review of the evidence." Prog Neurobiol 73(3): 179-226.

Pariante, C. M., P. Dazzan, et al. (2005). "Increased Pituitary Volume in Antipsychotic-Free and Antipsychotic-Treated Patients of the AEsop First-Onset Psychosis Study." Neuropsychopharmacology 30(10): 1923-31.

Rubin, D. B. (1997). "Estimating causal effects from large data sets using propensity scores." Ann Intern Med 127(8 Pt 2): 757-63.

Segal, M., A. Avital, et al. (2004). "Serum prolactin levels in unmedicated first-episode and recurrent schizophrenia patients: a possible marker for the disease's subtypes." Psychiatry Res 127(3): 227-35.

Shim, J. C., Y. H. Kim, et al. (2005). "Tardive dyskinesia predicts prolactin response to buspirone challenge in people with schizophrenia." J Neuropsychiatry Clin Neurosci 17(2): 221-6.

StataCorp. (2005). STATA Statistical Software: Release 9.1. Texas: College Station.

Tripodianakis, J., M. Markianos, et al. (1983). "Neurochemical studies on tardive dyskinesia. I. Urinary homovanillic acid and plasma prolactin." Biol Psychiatry 18(3): 337-45.

Turrone, P., M. V. Seeman, et al. (2000). "Estrogen receptor activation and tardive dyskinesia." Can J Psychiatry 45(3): 288-90.

van Os, J., T. Fahy, et al. (1997). "Tardive dyskinesia: who is at risk?" Acta Psychiatr Scand 96(3): 206-16.

Yuen, O., M. P. Caligiuri, et al. (1996). "Tardive dyskinesia and positive and negative symptoms of schizophrenia. A study using instrumental measures." British Journal of Psychiatry. 168(6): 702-8. 


\section{CHAPTER 7}

\section{Tardive Dyskinesia and Worsening of Psychosis: More than Just the Nigrostriatal Dopamine Tract?}

Diederik Tenback, Peter van Harten, Cees Slooff, Jim van Os, and the SOHO Study Group 


\begin{abstract}
Background: To examine a proxy psychopathological measure of dopaminergic mesolimbic and mesocortical signalling in relation to the incidence of tardive dyskinesia (TD), and test the hypothesis that dopamine tracts outside the extrapyramidal system contribute to variation in abnormal movements in patients with schizophrenia.
\end{abstract}

Methods:Simple, global measures of TD and CGI positive, negative, affective and cognitive symptoms, best represented by a single CGI overall symptom severity score, were rated in a prospective, observational study (SOHO). In a risk set free of TD at baseline, associations between TD onset and change in CGI scores, hypothesized to reflect underlying changes in neurochemical signalling, were assessed using Cox proportional hazard regression.

Results: 8620 patients yielded 23565 follow-up observations, 8.8\% of which represented a worsening in CGI overall symptom severity relative to the previous observation, yielding an incidence of TD of 5.2\%. The comparative TD incidence was $2.7 \%$ in observations without worsening of psychopathology (rate ratio: 1.9, 95\% CI: 1.3, 2.7). Cox regression showed that, independent of measures of parkinsonism, akathisia, dystonia and other confounders, incidence of TD was associated with a worsening of the CGI overall symptom severity in the months preceding TD onset (adjusted HR over 6 levels of CGI score=1.3, 95\% CI: 1.1, 1.4).

Conclusions: Worsening in overall psychopathology in schizophrenia may predict changes in abnormal movements. To the extent that changes in symptomatology reflect underlying alterations in dopaminergic mesolimbic and mesocortical signalling, TD may be the result of involvement of more than just the nigrostriatal dopamine tract. 


\section{INTRODUCTION}

Tardive dyskinesia has been associated with poor outcome in schizophrenia (Lieberman, Alvir et al. 1994; Murray and Van Os 1998). Symptoms of schizophrenia are thought to be associated with changes in the mesolimbic (positive symptoms) and mesocortical (negative and cognitive symptoms) pathways (Yuen, Caligiuri et al. 1996; Kapur and Mamo 2003). These pathways may also be involved in the aetiology of TD as previous longitudinal research has suggested that an increase in negative symptoms in schizophrenia is associated with an increase in TD (Caligiuri, Lacro et al. 1997; van Os, Walsh et al. 2000). Cognitive symptoms have also been invoked in relation to TD (Waddington and Youssef 1996), whereas little research has been devoted to the role of positive symptoms (White, Brown et al. 1991; Yuen, Caligiuri et al. 1996). The aim of the current prospective study was to examine to what degree changes in symptoms were associated with subsequent changes in TD, independent of other possible risk factors.

\section{METHODS}

\section{Design and Patients}

The SOHO study is an ongoing, 3-year, prospective, observational health outcome study of the treatment of schizophrenia in Europe (Haro, Edgell et al. 2003). Data was collected using a data collection form with a selection of measures that considered simplicity and ease of use with no training requirement. Investigators assessed the TD and EPS that they judged to be associated with antipsychotic drug treatment. TD was collected on a four-point scale: (1) not present, (2) present, but does not significantly interfere with patient's functioning or health-related quality of life, (3) present, and significantly interferes with patient's functioning or health-related quality of life, (4) present, and outweighs therapeutic effect. The validity of the TD scale, and the separate assessment of extrapyramidal side effects (EPS; parkinsonism, akathisia and dystonia) in SOHO, has been described previously(Tenback, van Harten et al. 2005), as has been the rating, similarly based on clinical judgement, of prolactin-related side effects (Tenback, van Harten et al. 2006).

Clinical severity was assessed using a scale based on the Clinical Global Impression (CGI) (Guy 1976), which evaluated positive, negative, cognitive, depressive and overall symptoms on the day of assessment. This was subsequently expanded and validated as the Clinical Global Impression-Schizophrenia scale (CGI-SCH) (Haro, Kamath et al. 2003), a scale that evaluates symptom severity during the week preceding the day of assessment. The CGI and CGI-SCH are physician-rated scales with values ranging from 0 (not ill) to 6 (among the most severely ill patients). 
Full details of the SOHO study design have been published previously (Haro, Edgell et al. 2003). Ethics Committee approval and informed consent was obtained as required by national regulations.

\section{Data Analysis}

\section{Incidence calculation}

In order to present descriptive data on whether any association between TD and change in psychopathology was specific for increase in psychopathology, rather than decrease or no change, a descriptive incidence analysis was conducted, in which individuals who did not present with TD at baseline were analyzed over the follow-up period to assess the incidence of TD in the following three groups i) the proportion who presented with an increase in CGI overall symptom severity relative to the previous observation, ii) the proportion of individuals who presented with a decrease in CGI overall symptom severity relative to the previous observation and iii) the proportion of individuals who presented with no change in CGI overall symptom severity relative to the previous observation. For the purposes of these analyses, TD was treated as a dichotomous outcome; present (score 2, 3 or 4) versus not present (score 1).

\section{Cox regression analyses}

In order to further examine any associations between TD and increase in CGI psychopathology, in terms of confounding for medication and other variables, and in order to assess possible dose-response relationships, regression analyses were conducted. All analyses were performed using the computer package STATA (StataCorp). Each individual had four observations: baseline, three-, six and twelvemonths follow-up.

In order to examine associations between incidence of TD and changes in psychopathology, 3 time bands were constructed (baseline-3 months, 3-6 months and 6-12 months) and each person was allocated person-time according to the interval from baseline to the visit in which a patient was diagnosed with TD or, if no such diagnosis was made, to the last visit.

As a principal component factor analysis of the four dimensions of positive, negative, depressive and cognitive symptoms revealed only one main global factor with an eigenvalue greater than unity on which all dimensions had high loadings (factor loadings between 0.70 and 0.85 ), explaining $63 \%$ of the variance, all analyses were conducted with the continuous CGI-SCH overall symptom severity score (scored 0 to 6). Because of small numbers in the highest category of CGI overall symptom severity (value 6), this category was merged with the category below (value 5), leaving six categories ranging form 0 to 5 .

In order to examine the relationship between TD and change in CGI overall symptom severity, associations between incident TD and CGI overall symptom severity measured on the same occasion as the TD rating, corrected for CGI overall symptom severity of the previous measurement occasion, were assessed using Cox pro- 
portional hazard regression yielding hazard ratios. This analysis effectively assesses the effect of CGI overall symptom severity change on TD. The Cox regression analyses were conducted in a risk set free of TD at baseline, and the CGI measures served as time-dependent covariates.

\section{Covariates}

Covariates were agreed upon by the $\mathrm{SOHO}$ advisory board and are hereafter referred to as SOHO-covariates. Covariates included the following time-varying and fixed variables measured at the time of TD and CGI assessment at 3,6 and 12 months: treatment with second generation (SGA) or first generation antipsychotic (FGA) (pre-and post assessment occasion), mono- or combination antipsychotic therapy, presence of parkinsonism, akathisia and dystonia, sex, age, age of first contact, body mass index, first episode status and other medications such as antidepressants, anticholinergics and mood stabilisers (full list of covariates available on request). As we have previously reported associations between incident TD and i) extra-pyramidal side effects (EPS) (Tenback, van Harten et al. 2005) and ii) presence of any prolactin-related side effects (loss of libido, amenorrhea or other menstrual disturbance, gynaecomastia, impotence or sexual dysfunction and galactorrhea) (Tenback, van Harten et al. 2005), associations were additionally adjusted for these two exposures so as to assess the relative independence of the current psychopathology exposure.

As observations were clustered within countries, the STATA CLUSTER and ROBUST options were used in the regression analyses. The CLUSTER option combined with the ROBUST option allows for the use of observations which are not independent within clusters (in this case: within countries), resulting in standard errors that are adjusted for clustering within countries.

Approximately $80 \%$ of the sample was included in the model with all covariates, due to covariate missing values.

Reported probability values for the predictor variable reflect two-sided tests of the null hypothesis of no association.

\section{RESULTS}

\section{Baseline Characteristics}

A total of 10,009 patients had non-missing data for TD and CGI overall symptom severity at baseline. The prevalence of TD in the 10,009 at baseline was $9.4 \%$; mean age was 40.1 years $(\mathrm{SD}=13.1), 57.7 \%$ were men and $10.0 \%$ were first episode. 


\section{Worsening of psychopathology and risk of TD}

Included in the analyses were 8620 individuals who did not present with TD at baseline and who had non-missing data for CGI overall symptom severity. In this risk set, there were 231 incident cases of TD over the follow-up period, representing a one-year incidence of $3.0 \%$ (95\% CI: 2.6, 3.4). Of the 23565 observations in the risk set, $2073(8.8 \%)$ represented an increase in the CGI overall symptom severity relative to the previous observation. These 2073 observations were associated with 39 incident cases of TD (incidence: $5.2 \%, 95 \%$ CI: 3.8, 7.1) compared to 193 incident TD cases in the remainder of the observations which represented reduction or no change in CGI overall symptom severity relative to the previous observation (incidence: $2.7,95 \%$ CI: 2.4, 3.2), representing a doubling in rate (rate ratio: 1.9, $95 \%$ CI: 1.3, 2.7). A similar rise in rate was seen neither for those with a reduction in the CGI overall symptom severity relative to the previous observation (incidence: $2.6 \%, 95 \%$ CI: $2.1,3.2$ ) in comparison with the remainder of the observations (no change or increase in CGI) (incidence: $3.2 \%, 95 \%$ CI: 2.8, 3.8; rate ratio: $0.8,95 \%$ CI: $0.6,1.1)$ nor for those with no change in the CGI overall symptom severity relative to the previous observation (incidence: $2.9 \%, 95 \%$ CI: $2.4,3.4$ ) in comparison with the remainder of the observations (reduction or increase in CGI) (incidence: $3.1 \%, 95 \%$ CI: $2.6,3.7$; rate ratio: $0.9,95 \%$ CI: $0.7,1.2$ ).

\section{Cox regression with continuous CGI score}

In the Cox regression analyses with the 6-level continuous CGI overall symptom severity score adjusted for the CGI score on the previous measurement occasion, change in psychopathology predicted TD incidence (unadjusted $\mathrm{HR}=1.5,95 \% \mathrm{CI}$ : $1.3,1.6)$, with a monotonic dose response relationship being apparent over the 6 levels of CGI psychopathology (Table 1). In the analysis adjusted for SOHOcovariates with the exception of EPS and prolactin-related side effects, the effect size was not reduced $(\mathrm{HR}=1.5,95 \% \mathrm{CI}: 1.3,1.7)$, nor was it reduced much $(20 \%$ reduction) when prolactin-related side effects were added to the list of SOHOcovariates (HR=1.4, 95\% CI: 1.3, 1.6). When EPS was adjusted for in addition to the SOHO-covariates, the effect size was reduced more ( $40 \%$ reduction) although still remaining significant $(\mathrm{HR}=1.3,95 \% \mathrm{CI}: 1.1,1.4)$.

\section{DISCUSSION}

The results showed that increase in CGI overall symptom severity was specifically associated with incidence of TD, and that there was a dose-response relationship, suggestive for underlying causality (Hill 1965), between worsening of psychosis and incidence of TD independent of a broad range of possible confounders. To the degree that change in psychopathology reflects underlying dopaminergic mesolimbic and mesocortical signalling, the results support the hypothesis that dopamine 
tracts outside the extrapyramidal system contribute to variation in abnormal movements in patients with schizophrenia.

Our measures of symptomatology did not allow for dimension-specific analyses and therefore the hypothesis that only worsening in negative and cognitive symptoms contributed to the change in TD incidence relative to changes in depressive and positive symptoms could not be examined. Although negative and cognitive symptoms are well known risk-factors for TD, no meta-analytic work has examined their effects across research reports. There is a limited (Yuen, Caligiuri et al. 1996) and contradictory (White, Brown et al. 1991) level of proof for positive symptoms. The findings, nevertheless, confirm the initial hypothesis that worsening of schizophrenia symptoms is a risk factor for TD (Lieberman, Alvir et al. 1994; Chakos, Alvir et al. 1996; Murray and Van Os 1998), independent of EPS such as parkinsonism, akathisia and dystonia.

EPS reduced the effect size of the association between worsening of psychosis and TD by $40 \%$. The reduction of the effect size might reflect a change in antipsychotic and/or concurrent medication following worsening of the CGI. However, antipsychotic (first- versus second generation; mono- versus polytherapy ) and other medications were included as covariates and therefore controlled for and TD, EPS and poor symptomatic outcome may share a similar mechanism which is compatible with an earlier report from this sample linking early EPS to later TD (Tenback, van Harten et al. 2005). Similarly, a recent study on treatment of severe TD identified the early change of the Parkinson score as the most significant predictor for response(Bai, Yu et al. 2005). Indirect evidence that EPS and TD might have a similar pathophysiological basis, albeit with a different temporal order of incidence, is supported by reports of high rates of EPS and TD comorbidity (Lauterbach, Carter et al. 2001), although both positive (Muscettola, Barbato et al. 1999) and negative associations between parkinsonism and TD have been reported (van Harten, Hoek et al. 1997).

As SGA have a lesser propensity for TD (Correll, Leucht et al. 2004; Tenback, van Harten et al. 2005) and recent meta-analytic work has shown reduced relapse rates with SGA (Davis, Chen et al. 2003; Leucht, Barnes et al. 2003), the possibility of reciprocity between symptoms and TD shown in this report suggest new avenues for future research in schizophrenia. 
Table 1 dose-response relationship worsening psychopathology and risk TD

\begin{tabular}{|l|l|l|}
\hline $\begin{array}{l}\text { Worsening psychopathology in } \\
\text { CGI points }\end{array}$ & Hazard Ratio & $95 \%$ Confidence Interval \\
\hline 1 & $1.0^{\mathrm{a}}$ & \\
\hline 2 & 1.0 & $0.3,3.3$ \\
\hline 3 & 1.5 & $0.4,5.0$ \\
\hline 4 & 2.2 & $0.6,7.9$ \\
\hline 5 & 3.2 & $0.9,10.9$ \\
\hline 6 & 5.2 & $1.6,17.1$ \\
\hline Linear trend unadjusted $^{\mathrm{b}}$ & 1.5 & $1.3,1.6$ \\
\hline Linear trend adjusted $^{\mathrm{b}}$ & 1.5 & $1.3,1.7$ \\
\hline Linear trend adjusted $^{\mathrm{c}}$ & 1.4 & $1.3,1.6$ \\
\hline Linear trend adjusted $^{\mathrm{d}}$ & 1.3 & $1.1,1.4$ \\
\hline
\end{tabular}

${ }^{a}$ reference category

${ }^{\mathrm{b}}$ Adjusted for SOHO-covariates (see text for description)

${ }^{\mathrm{c}}$ Adjusted for SOHO-covariates and prolactin-related side effects

${ }^{\mathrm{d}}$ Adjusted for SOHO-covariates and EPS 


\section{REFERENCES:}

Bai, Y. M., S. C. Yu, et al. (2005). "Risperidone for pre-existing severe tardive dyskinesia: a 48week prospective follow-up study." Int Clin Psychopharmacol 20(2): 79-85.

Caligiuri, M. P., J. P. Lacro, et al. (1997). "Incidence and risk factors for severe tardive dyskinesia in older patients." Br J Psychiatry 171: 148-53.

Chakos, M. H., J. M. Alvir, et al. (1996). "Incidence and correlates of tardive dyskinesia in first episode of schizophrenia." Arch Gen Psychiatry 53(4): 313-9.

Correll, C. U., S. Leucht, et al. (2004). "Lower risk for tardive dyskinesia associated with secondgeneration antipsychotics: a systematic review of 1-year studies." Am J Psychiatry 161(3): 414-25.

Davis, J. M., N. Chen, et al. (2003). "A meta-analysis of the efficacy of second-generation antipsychotics." Arch Gen Psychiatry 60(6): 553-64.

Guy, W. (1976). American Psychiatric Association. Task Force for the Handbook of Psychiatric Measures. (2000). Handbook of psychiatric measures. Washington, DC: American Psychiatric Association. Pg.100-102.

Haro, J. M., E. T. Edgell, et al. (2003). "The European Schizophrenia Outpatient Health Outcomes (SOHO) study: rationale, methods and recruitment." Acta Psychiatr Scand 107(3): 222-32.

Haro, J. M., S. A. Kamath, et al. (2003). "The Clinical Global Impression-Schizophrenia scale: a simple instrument to measure the diversity of symptoms present in schizophrenia." Acta Psychiatr Scand Suppl(416): 16-23.

Hill, A. B. (1965). "The Environment and Disease: Association or Causation?" Proc R Soc Med 58: 295-300.

Kapur, S. and D. Mamo (2003). "Half a century of antipsychotics and still a central role for dopamine D2 receptors." Prog Neuropsychopharmacol Biol Psychiatry 27(7): 1081-90.

Lauterbach, E. C., W. G. Carter, et al. (2001). "Tardive dyskinesia--diagnostic issues, subsyndromes, and concurrent movement disorders: a study of state hospital inpatients referred to a movement disorder consultation service." Schizophr Bull 27(4): 601-13.

Leucht, S., T. R. Barnes, et al. (2003). "Relapse prevention in schizophrenia with new-generation antipsychotics: a systematic review and exploratory meta-analysis of randomized, controlled trials." Am J Psychiatry 160(7): 1209-22.

Lieberman, J. A., J. Alvir, et al. (1994). "Methylphenidate response, psychopathology and tardive dyskinesia as predictors of relapse in schizophrenia." Neuropsychopharmacology 11(2): $107-18$.

Murray, R. M. and J. Van Os (1998). "Predictors of outcome in schizophrenia." J Clin Psychopharmacol 18(2 Suppl 1): 2S-4S.

Muscettola, G., G. Barbato, et al. (1999). "Extrapyramidal syndromes in neuroleptic-treated patients: prevalence, risk factors, and association with tardive dyskinesia." J Clin Psychopharmacol 19(3): 203-8.

StataCorp "(2002): STATA Statisctical Software: Release 8.0. Texas: College Station."

Tenback, D. E., P. N. van Harten, et al. (2005). "Effects of Antipsychotic Treatment on Tardive Dyskinesia: A 6-Month Evaluation of Patients From the European Schizophrenia Outpatient Health Outcomes (SOHO) Study." J Clin Psychiatry 66(9): 1130-1133.

Tenback, D. E., P. N. van Harten, et al. (2006). "Tardive dyskinesia in schizophrenia is associated with prolactin-related sexual disturbances." Neuropsychopharmacology 31(8): 1832-7.

Tenback, D. E., P. N. van Harten, et al. (2006). "Evidence That Early Extrapyramidal Symptoms Predict Later Tardive Dyskinesia: A Prospective Analysis of 10,000 Patients in the European 
Schizophrenia Outpatient Health Outcomes (SOHO) Study." Am J Psychiatry 163(8): 143840.

van Harten, P. N., H. W. Hoek, et al. (1997). "The inter-relationships of tardive dyskinesia, parkinsonism, akathisia and tardive dystonia: the Curacao Extrapyramidal Syndromes Study II." Schizophr Res 26(2-3): 235-42.

van Os, J., E. Walsh, et al. (2000). "Changes in negative symptoms and the risk of tardive dyskinesia: a longitudinal study. UK700 Group." Acta Psychiatrica Scandinavica. 101(4): 300-6.

Waddington, J. L. and H. A. Youssef (1996). "Cognitive dysfunction in chronic schizophrenia followed prospectively over 10 years and its longitudinal relationship to the emergence of tardive dyskinesia." Psychol Med 26(4): 681-8.

White, T., K. W. Brown, et al. (1991). "Tardive dyskinesia and positive symptoms of schizophrenia." Acta Psychiatr Scand 83(5): 377-9.

Yuen, O., M. P. Caligiuri, et al. (1996). "Tardive dyskinesia and positive and negative symptoms of schizophrenia. A study using instrumental measures." British Journal of Psychiatry. 168(6): 702-8. 


\section{CHAPTER 8}

\section{Incidence and Subsequent Persistence of Tardive Dyskinesia and Extrapyramidal Symptoms in Schizophrenia: Markers of Progressive Dopamine Sensitivity?}




\begin{abstract}
:
Objective: To assess the morbidity force of movement disorder in the era of second generation antipsychotics (SGA), by calculating the incidence and persistence of Tardive Dyskinesia (TD) and Extra Pyramidal Symptoms (EPS) in a cohort of patients with schizophrenia treated predominantly with SGA, over a period of two years.
\end{abstract}

Methods: A cohort of more than 10,000 patients with schizophrenia was seen 6 times over a period of 2 years. Dichotomous measures of EPS and TD were used to calculate the yearly incidence rates of TD and EPS as well as their subsequent persistence rate.

Results: Of 9104 individuals who did not present with TD at baseline, 138 developed TD, yielding a TD incidence rate of $0.74 \%$ (95\% CI: $0.62,0.87)$. The subsequent persistence rate in these 138 individuals was $48.6 \%$ (95\% CI: 37.3, 57.8). Of 6285 individuals without EPS at baseline, 464 developed EPS yielding an incidence rate of $3.7 \%(95 \% \mathrm{CI}: 3.4,4.0)$, and a subsequent EPS persistence rate of $55.5 \%$ (95\% CI: 50.1, 60.3).

Conclusion: Incidence rates of TD and EPS are considerably lower in the SGA era. However, once emerged, these disorders prove highly persistent suggesting strong moderator effects of underlying predisposing factors. The contrast between low incidence and high persistence provides support for the hypothesis of gradually progressive dopamine hypersensitivity. 


\section{INTRODUCTION}

Before the advent of the so-called Second Generation Antipsychotics (SGA), rates of Tardive dyskinesia (TD) and extrapyramidal symptoms (EPS) in schizophrenia were high. Thus, the estimated yearly incidence rate of TD was $5 \%$ (Kane, Woerner et al. 1984; Correll, Leucht et al. 2004), with an associated persistence rate of $32 \%, 57 \%$ and $68 \%$ after respectively 5,15 and 25 years of first-generation antipsychotic (FGA) exposure(Morgenstern and Glazer 1993). Prevalence rates of TD persistence in the literature range from $38 \%$ to $80 \%$ (Kane, Woerner et al. 1986; Bergen, Eyland et al. 1989; Glazer, Morgenstern et al. 1991; Yassa and Nair 1992; Fernandez, Krupp et al. 2001). The yearly incidence rate of EPS in never-medicated patients in the FGA era was also high at an estimated 34\% (Chakos, Alvir et al. 1996), with rates of subsequent persistence as high as $87 \%$ (Fernandez, Krupp et al. 2001). Currently, however, many patients with schizophrenia are treated with SGA, that are associated with a lower incidence of TD than FGA (Correll, Leucht et al. 2004; Tenback, van Harten et al. 2005). There is also some evidence that SGA may reduce the burden of existing TD (Emsley, Turner et al. 2004; Tenback, van Harten et al. 2005).

In order to re-quantify the movement disorder morbidity force in the SGA era, prospective data from a large cohort of patients in routine clinical settings treated predominantly with SGA were used to: (i) calculate incidence rates of TD and EPS and (ii) quantify their subsequent persistence.

\section{METHODS}

\section{Design and Patients}

The SOHO study is an ongoing, 3-year, prospective, observational, health outcome study of the treatment of schizophrenia in Europe. Data was collected with a selection of measures that considered simplicity and ease of use with no training requirement. Investigators assessed the TD and EPS (defined as dystonia, akathisia, or parkinsonism) that they observed during treatment with antipsychotic medication. TD and EPS were separately collected on a four-point scale: (1) not present, (2) present, but does not significantly interfere with patient's functioning or healthrelated quality of life, (3) present, significantly interferes with patient's functioning or health-related quality of life, (4) present, outweighs therapeutic effect.

Full details of the SOHO study design have been published previously (Haro, Edgell et al. 2003). Ethics Committee approval and informed consent was obtained as required by national regulations. 


\section{Data Analysis}

Each individual had six observations: baseline, 3, 6, 12 and 24-month follow-up. For the purpose of these analyses, EPS and TD were treated as dichotomous outcomes (present $=$ score 2,3 or 4 vs. not present $=$ score 1 ). In order to calculate the incidence rates of TD and EPS, 5 time bands were constructed (baseline to 3, 3 to 6, 6 to 12,12 to 18 and 18 to 24 months). Each person was allocated person-time according to the interval from baseline to the visit in which a patient was diagnosed with TD or, if no such diagnosis was made, to the last visit.

Incidence rates for each time band were calculated by dividing the number of incident cases by the person years. The total incidence of TD and EPS was calculated by dividing the total number of incident cases of TD or EPS by the total person years. An incident case was defined as a case meeting the criteria for EPS or TD for the first time for at least two consecutive assessments (thus the first time a new case could arise was between 3 and 6 months at the second assessment after baseline). This is in line with the (TD) Research Diagnostic Criteria for a persistent case (Schooler and Kane 1982). The group with incident movement disorders served as risk set for survival analyses for persistence of TD and EPS; censoring occurred when movement disorder was no longer observed (thus the first time an incident case could be rated as recovered was between 9 and 12 months at the third assessment after baseline: no movement disorder at baseline, presence of movement disorder at 3 and 6 months, and no movement disorder at 12 months).

All analyses used the STATA programme, version 9.1 (StataCorp 2002).

\section{RESULTS}

\section{Baseline Characteristics}

A total of 10029 patients had non-missing data for TD and EPS at baseline. The prevalence of TD and EPS in these 10029 were $936(9.3 \%)$ and $3773(37.6 \%)$ respectively. The mean age of these 10029 was 39.6 years $(\mathrm{SD}=13.1), 57.2 \%$ were men, $10.0 \%$ were first episode and $28.5 \%$ had been exposed to an SGA in the 6 months prior to enrolment. After the baseline assessment, this proportion rose to $85.9 \%$.

\section{Incidence of TD and EPS}

Included in the TD incidence analyses were 9104 individuals who did not present with TD at baseline. In this risk set, there were 138 incident cases of TD over the follow-up period, yielding a yearly TD incidence rate of $0.74 \%$ (95\% CI: 0.62 , 0.87). In the EPS analyses, the risk set consisted of 6285 individuals without EPS at baseline; of these, 464 incident cases yielded a yearly EPS incidence rate of $3.7 \%$ (95\% CI: 3.4, 4,0) (Table1). 


\section{Persistence of TD and EPS}

The TD persistence analysis was conducted in a risk set of 138 subjects. Over the follow-up period, there were $98 \mathrm{TD}$ cases that did not persist, after correction for person-time yielding a yearly TD persistence rate of $48.6 \%$ (95\% CI: 37.3, 57.8). The EPS risk set consisted of 464 subjects. Of these, 298 were censored over the follow-up, yielding a yearly EPS persistence rate of 55.5\% (95\% CI: 50.1, 60.3) (Table 2).

\section{DISCUSSION}

In the current analyses, a low rate of incident EPS and TD was found, in line with previous reports of lower incidence of TD and EPS with SGA treatment (Geddes, Freemantle et al. 2000; Correll, Leucht et al. 2004). However, fully half of the patients, once they developed EPS and TD whilst on SGA treatment, displayed a chronic course of movement disorder. Although reports from the FGA era reveal similar persistence rates(Bergen, Eyland et al. 1989; Koshino, Wada et al. 1991; Yassa and Nair 1992; Fernandez, Krupp et al. 2001), attention for TD is currently waning because of lower incidence and possibly better prognosis with the advent of SGA (Correll, Leucht et al. 2004) (Emsley, Turner et al. 2004; Tenback, van Harten et al. 2005). However, the high persistence rates in the current report give rise to concern and have clinical consequences. Low incidence rates in combination with a high probability of persistence may be explained by an extension of the original dopamine theory of TD (Gerlach 1977; Davis, Kahn et al. 1991). Thus, it may be hypothesized that TD and EPS are not just side effects of antipsychotic medication, but rather core symptoms of schizophrenia and a possible marker for the course of schizophrenia (Murray and Van Os 1998), mediated by an underlying phenomenon of slowly progressive dopamine (D2) receptor sensitivity. According to this theory, gradually progressive D2 receptor sensitivity may not only explain the emergence of progressively more unresponsive psychotic symptoms, but also the appearance of the motor symptoms seen in schizophrenia (Schroder, Silvestri et al. 1998; Tenback, van Harten et al. 2006). TD and EPS may thus represent a pathophysiological marker of the disease pathophysiology itself, even though exposure to FGA may further worsen the motor manifestations associated with the disease, and SGA may improve it (Tenback, van Harten et al. 2005). The hypothesis of TD and EPS as markers of underlying disease pathophysiology is compatible with reports of spontaneous TD prevalence rates of $25 \%$ in never-medicated patients with schizophrenia aged 30 to 50 years (Fenton 2000) and reports of EPS rates ranging from $17 \%$ to $30 \%$ in never-medicated patients (Chatterjee, Chakos et al. 1995; Honer, Kopala et al. 2005). Tarbox and colleagues reviewed the literature and calculated the average percentage of spontaneous dyskinesia weighted by sample size in relatives of patients, and found higher rates (19\%-24\%) compared to controls (11\%) (Tarbox and Pogue-Geile 2006), suggesting that movement disorder may be associated with the disease liability itself. The authors, however, failed to replicate these findings in 
their own sample (Tarbox and Pogue-Geile 2006). A recent twin study reported that the unaffected co-twins of patients had increased caudate D2 density compared to healthy control twins, implicating that D2 receptor up-regulation is related to the liability for schizophrenia (Hirvonen, van Erp et al. 2005). In a SPECT study of patients with schizophrenia receiving antipsychotic therapy (Schroder, Silvestri et al. 1998), evidence was presented that a subgroup of patients with D2 receptor upregulation may be characterized by poor treatment response and pronounced EPS. Earlier reports analysing data from the sample presented in the current study suggested a phenomenon of "pandopaminergic involvement" underlying the covariation of TD on the one hand and endocrine, psychopathological and other motor signs and symptoms on the other (Tenback, van Harten et al. 2005; Tenback, van Harten et al. 2005; Tenback, van Harten et al. 2006).

It is therefore proposed that the contrast between low incidence and high persistence can be usefully linked to the hypothesis of gradually progressive dopamine hypersensitivity providing the following outcomes: i) if sensitivity is mild, individuals will probably not develop TD; ii) if sensitivity is moderate, TD will develop with moderate stressors of the dopamine system (eg FGA), and may be reversed by subsequent exposure to SGA; iii) if sensitivity is marked, individuals will develop TD with even mild stressors of the DA system (eg SGA); iv) sensitivity is severe, meaning that individuals will develop TD, with or without environmental exposures such as antipsychotic medication. Thus, when patients develop TD and EPS whilst on FGA, a proportion with a less sensitive dopamine system could still respond to treatment of motor symptoms with an SGA. However, those with a highly sensitive dopamine system will develop TD even while on SGA and therefore will also subsequently show high rates of persistence.

There are limitations to our findings. Firstly, incidence of EPS and TD and their subsequent persistence should ideally be measured in a first episode group. The TD incidence rate is greatest during the first 5 years of antipsychotic exposure (Morgenstern and Glazer 1993), probably representing patients with the most sensitive dopamine systems. These patients would have been excluded from our incidence and subsequent persistence analysis. Secondly, intrinsic to survival analysis, individuals can only experience the event of TD or EPS once, while in some individuals this event might represent the fluctuating course of TD or EPS causing it to disappear and emerge again over subsequent visits. The approach used therefore may have underestimated the incidence and subsequent persistence of TD or EPS, while the employment of the Research Diagnostic Criteria for a persistent case(Schooler and Kane 1982)may bias towards lower incidence rates but higher subsequent persistence rates. 
Table 1 Incidence rates of TD derived by Cox Proportional-Hazards Regression in 9104 and 6285 patients free of TD and EPS respectively

\begin{tabular}{|l|l|l|l|l|}
\hline \multirow{2}{*}{$\begin{array}{l}\text { Visit } \\
\text { number }\end{array}$} & \multicolumn{2}{|l|}{ Tardive Dyskinesia } & \multicolumn{2}{l|}{ Extrapyramidal Symptoms } \\
\cline { 2 - 5 } & $\begin{array}{l}\text { Number of patients } \\
\text { with incident TD }\end{array}$ & Incidence (\%) & $\begin{array}{l}\text { Number of patients } \\
\text { with incident EPS }\end{array}$ & Incidence (\%) \\
\hline 3 & 41 & 0.87 & 208 & 6.4 \\
\hline 4 & 30 & 0.61 & 90 & 2.6 \\
\hline 5 & 35 & 0.77 & 94 & 3.1 \\
\hline 6 & 32 & 0.70 & 72 & 2.4 \\
\hline Total & 138 & 0.74 & 464 & 3.7 \\
\hline
\end{tabular}

Table 2 Persistence rates of TD and EPS derived by Cox Proportional-Hazards Regression in 138 and 464 patients with symptoms of TD and EPS respectively

\begin{tabular}{|l|l|l|l|l|}
\hline \multirow{2}{*}{$\begin{array}{l}\text { Visit } \\
\text { number }\end{array}$} & \multicolumn{2}{|l|}{ Tardive Dyskinesia } & \multicolumn{2}{l|}{ Extrapyramidal Symptoms } \\
\cline { 2 - 5 } & $\begin{array}{l}\text { Number of patients } \\
\text { in remission }\end{array}$ & Persistence (\%) & $\begin{array}{l}\text { Number of patients } \\
\text { in remission }\end{array}$ & Persistence (\%) \\
\hline 4 & 77 & 43.0 & 218 & 51.8 \\
\hline 5 & 12 & 61.6 & 59 & 52.5 \\
\hline 6 & 9 & 62.7 & 21 & 77.4 \\
\hline Total & 98 & 48.6 & 298 & 55.5 \\
\hline
\end{tabular}




\section{REFERENCES}

Bergen, J. A., E. A. Eyland, et al. (1989). "The course of tardive dyskinesia in patients on longterm neuroleptics." Br J Psychiatry 154: 523-8.

Chakos, M. H., J. M. Alvir, et al. (1996). "Incidence and correlates of tardive dyskinesia in first episode of schizophrenia." Arch Gen Psychiatry 53(4): 313-9.

Chatterjee, A., M. Chakos, et al. (1995). "Prevalence and clinical correlates of extrapyramidal signs and spontaneous dyskinesia in never-medicated schizophrenic patients." Am J Psychiatry 152(12): 1724-9.

Correll, C. U., S. Leucht, et al. (2004). "Lower risk for tardive dyskinesia associated with secondgeneration antipsychotics: a systematic review of 1-year studies." Am J Psychiatry 161(3): 414-25.

Davis, K. L., R. S. Kahn, et al. (1991). "Dopamine in schizophrenia: a review and reconceptualization." Am J Psychiatry 148(11): 1474-86.

Emsley, R., H. J. Turner, et al. (2004). "A single-blind, randomized trial comparing quetiapine and haloperidol in the treatment of tardive dyskinesia." J Clin Psychiatry 65(5): 696-701.

Fenton, W. S. (2000). "Prevalence of spontaneous dyskinesia in schizophrenia." J Clin Psychiatry 61 Suppl 4: 10-4.

Fernandez, H. H., B. Krupp, et al. (2001). "The course of tardive dyskinesia and parkinsonism in psychiatric inpatients: 14-year follow-up." Neurology 56(6): 805-7.

Geddes, J., N. Freemantle, et al. (2000). "Atypical antipsychotics in the treatment of schizophrenia: systematic overview and meta-regression analysis." Bmj 321(7273): 1371-6.

Gerlach, J. (1977). "The relationship between parkinsonism and tardive dyskinesia." Am J Psychiatry 134(7): 781-4.

Glazer, W. M., H. Morgenstern, et al. (1991). "The prediction of chronic persistent versus intermittent tardive dyskinesia. A retrospective follow-up study." Br J Psychiatry 158: 822-8.

Haro, J. M., E. T. Edgell, et al. (2003). "The European Schizophrenia Outpatient Health Outcomes (SOHO) study: rationale, methods and recruitment." Acta Psychiatrica Scandinavica. 107(3): 222-32.

Hirvonen, J., T. G. van Erp, et al. (2005). "Increased caudate dopamine D2 receptor availability as a genetic marker for schizophrenia." Arch Gen Psychiatry 62(4): 371-8.

Honer, W. G., L. C. Kopala, et al. (2005). "Extrapyramidal symptoms and signs in first-episode, antipsychotic exposed and non-exposed patients with schizophrenia or related psychotic illness." J Psychopharmacol 19(3): 277-85.

Kane, J. M., M. Woerner, et al. (1986). "Integrating incidence and prevalence of tardive dyskinesia." Psychopharmacol Bull 22(1): 254-8.

Kane, J. M., M. Woerner, et al. (1984). "Incidence of tardive dyskinesia: five-year data from a prospective study." Psychopharmacol Bull 20(3): 387-9.

Koshino, Y., Y. Wada, et al. (1991). "A long-term outcome study of tardive dyskinesia in patients on antipsychotic medication." Clin Neuropharmacol 14(6): 537-46.

Morgenstern, H. and W. M. Glazer (1993). "Identifying risk factors for tardive dyskinesia among long-term outpatients maintained with neuroleptic medications. Results of the Yale Tardive Dyskinesia Study." Arch Gen Psychiatry 50(9): 723-33.

Murray, R. M. and J. Van Os (1998). "Predictors of outcome in schizophrenia." J Clin Psychopharmacol 18(2 Suppl 1): 2S-4S.

Schooler, N. R. and J. M. Kane (1982). "Research diagnoses for tardive dyskinesia." Arch Gen Psychiatry 39(4): 486-7. 
Schroder, J., S. Silvestri, et al. (1998). "D2 dopamine receptor up-regulation, treatment response, neurological soft signs, and extrapyramidal side effects in schizophrenia: a follow-up study with 123I-iodobenzamide single photon emission computed tomography in the drug-naive state and after neuroleptic treatment." Biol Psychiatry 43(9): 660-5.

StataCorp (2002). STATA Statisctical Software: Release 8.0. Texas, College Station.

Tarbox, S. I. and M. F. Pogue-Geile (2006). "Spontaneous dyskinesia and familial liability to schizophrenia." Schizophr Res 81(2-3): 125-37.

Tenback, D. E., P. N. van Harten, et al. (2005). "Effects of Antipsychotic Treatment on Tardive Dyskinesia: A 6-Month Evaluation of Patients From the European Schizophrenia Outpatient Health Outcomes (SOHO) Study." J Clin Psychiatry 66(9): 1130-1133.

Tenback, D. E., P. N. van Harten, et al. (2006). "Tardive Dyskinesia and Worsening of Psychosis: More than Just the Nigrostriatal Dopamine Tract?" Submitted to Acta Psychiatr Scand.

Tenback, D. E., P. N. van Harten, et al. (2006). "Tardive dyskinesia in schizophrenia is associated with prolactin-related sexual disturbances." Neuropsychopharmacology 31(8): 1832-7.

Tenback, D. E., P. N. van Harten, et al. (2006). "Evidence That Early Extrapyramidal Symptoms Predict Later Tardive Dyskinesia: A Prospective Analysis of 10,000 Patients in the European Schizophrenia Outpatient Health Outcomes (SOHO) Study." Am J Psychiatry 163(8): 143840.

Yassa, R. and N. P. Nair (1992). "A 10-year follow-up study of tardive dyskinesia." Acta Psychiatr Scand 86(4): 262-6. 


\section{CHAPTER 9}

\section{Epilogue}

\section{INTRODUCTION}

Although TD is regarded by most psychiatrists as a side effect of antipsychotic medication, one could argue that this is too narrow a view and therefore presents an interesting area for further investigation. The facts that: i) schizophrenia is the only psychiatric disorder in which antipsychotic naïve patients display signs of TD (Fenton 2000), and ii) first degree relatives of schizophrenia patients can display signs of TD (Egan, Hyde et al. 2001) suggest TD as a marker for schizophrenia susceptibility. Besides this, TD can be considered a marker for disease severity, as it predicts a bad outcome with regard to the course of the illness (Chatterjee, Chakos et al. 1995; Schroder, Silvestri et al. 1998). As a marker for schizophrenia as well as a predictive marker for potential disease severity, TD in schizophrenia is an interesting phenomenon well worth studying in the context of the study of the pathophysiological basis of schizophrenia.

\section{Research Hypothesis}

Since imaging studies show D2 dopamine up-regulation in the nigrostriatal pathways (Silvestri, Seeman et al. 2000; Hirvonen, van Erp et al. 2005), especially in patients with a poor prognosis (Schroder, Silvestri et al. 1998), we hypothesized that a D2 supersensitivity might not be restricted to the nigrostriatal pathway alone, but that the pan-dopaminergic system could be involved in the pathophysiological basis of TD, and thus of schizophrenia (assuming TD is an early marker for disease severity).

Several proxy measures representing the different dopamine tracts as predictors for the emergence of TD in schizophrenia were examined: i) EPS as a proxy for the nigrostriatal dopamine tract; ii) sexual adverse events as a proxy for the tuberoinfundibular dopamine tract; iii) worsening of psychosis represented by a worsening of the CGI as a proxy for the mesolimbic and mesocortical dopamine tract.

The sample was not suitable for other, more detailed, proxy measures for the mesocortical and mesolimbic dopamine tracts such as cognitive and positive symptoms, as the CGI schizophrenia, which measured all schizophrenia symptom clusters, did not differentiate in a factor analysis. 
This thesis describes the pandopaminergic involvement in emergent TD together with antipsychotic medication as a differential exogenous risk factor for the pandopaminergic tract for emergence of TD. When TD emerges under FGA, TD has a higher rate of reversibility than when emerging under SGA. Combining the findings of the different chapters into a coherent hypothesis, a framework is proposed of pandopaminergic supersensitivity influenced by exogenous factors.

\section{SUMMARY AND IMPLICATIONS OF FINDINGS}

\section{Little Evidence of Risk Factors for Onset of Tardive Dyskinesia in Schizophrenia}

Since genetic susceptibility and the environment contribute to the phenotype, we started with evaluating the current risk factors for schizophrenia as set out in the literature dealing with environmental and other factors.

A systematic review of this literature, and a subsequent meta analysis of the results on risk factors for emergent Tardive Dyskinesia in a prospectively followed up population with schizophrenia and free of TD on baseline, revealed only akathisia as a risk factor for the emergence of TD, besides FGA, which was the subject of another recent meta analysis (Correll, Leucht et al. 2004).

\section{Effects of Antipsychotic Treatment on Tardive Dyskinesia}

The differential effect of FGA and SGA was demonstrated by comparing the incidence and persistence of TD using a simple, global measure of TD rated by participating clinicians. Data at baseline, three, and six months was analyzed using a generalized estimating equation (GEE) model. Not only did SGA confer a lower risk for 6-month TD than FGA ( $0.9 \%$ vs. $3.8 \%$, OR=0.29, $95 \% \mathrm{CI}=0.18-0.46)$, but in addition, patients with TD at baseline on SGA were less likely to have TD symptoms at 6 months $(43.6 \%$ vs. $60.8 \%, \mathrm{OR}=0.50,95 \% \mathrm{CI}=0.30-0.85)$. As well as a reduced incidence rate of emergent TD for SGA (Correll, Leucht et al. 2004), the results suggested a possible ameliorative effect of SGA on existing TD..

Evidence that Early EPS predicts Later Tardive Dyskinesia.

The nigrostriatal dopamine tract has long been implicated in the pathophysiology of TD(Casey 2004). Many studies have looked at early EPS as a risk factor for TD (Chouinard, Annable et al. 1988; Chakos, Alvir et al. 1996; Sachdev 2004). When combining results meta analytically however, they failed to reach significance in a random effects model. Our study replicated early EPS as a risk factor for TD in a large cohort of schizophrenia patients. 
Tardive Dyskinesia in Schizophrenia is Associated with Prolactin-Related Sexual Disturbances

The tubero-infundibular dopamine pathway regulates, by inhibition, pituitary prolactin secretion. Deregulation of the tubero-infundibular dopamine pathway, through, for example, prolactin elevation caused by the mechanism of dopamine blockade by antipsychotics can cause sexual adverse events such as loss of libido, amenorrhea, gynaecomastia, impotence and galactorrhea. Although the sexual disturbances seen in schizophrenia are of multifactorial origin, and therefore only in part attributable to illness-related or medication-related prolactin levels, they may nevertheless serve as an indirect measure for prolactin elevation in epidemiological studies, in particular if numerous confounding variables can be adequately controlled for (Halbreich, Kinon et al. 2003; Knegtering, van der Moolen et al. 2003; Haddad and Wieck 2004).

Cox regression analysis showed the incidence of TD to be significantly and linearly comorbid with the incidence of Prolactin Related Sexual Disturbances (PRSD) in both men and women. These findings should not be interpreted as medication effects, as associations were stronger in those who had only received prolactinsparing medications than in those who only had received prolactin-raising medications. Thus emergent TD in schizophrenia is not limited to the nigrostriatal dopamine tract, the tuberoinfundibular dopamine tract is involved as well.

\section{Tardive Dyskinesia and Worsening of Psychosis}

We had hoped to test proxy measures of the mesolimbic and mesocortical dopamine tracts using a Cox regression analysis. To achieve this we needed positive, negative, and cognitive symptom measures of schizophrenia. Yet a principal component factor analysis of the four dimensions of positive, negative, depressive, and cognitive symptoms revealed only one main global factor with an eigen value greater than unity on which all dimensions had high loadings, explaining the majority of the variance. Therefore all analyses were conducted with the continuous CGI-SCH overall symptom severity score. The effect of CGI overall symptom severity change on emergence of TD was analyzed using a Cox regression analysis. Incidence of TD was associated with a worsening of the CGI overall symptom severity score in the months preceding TD onset.

Incidence and Subsequent Persistence of Tardive Dyskinesia and Extrapyramidal Symptoms in Schizophrenia: Markers of Progressive Dopamine Sensitivity?

The fact that SGA have a slightly better outcome with regards to treatment response (Davis, Chen et al. 2003; Leucht, Barnes et al. 2003), combined with the differential effect of SGA and FGA on the nigrostriatal D2 receptor occupancy (Kessler, Ansari et al. 2005), as well as the notion that TD predicts a worse treatment response in schizophrenia (Chatterjee, Chakos et al. 1995; Schroder, Silvestri et al. 1998), created our interest in patients who would develop TD despite the use of SGA. In this 
context we analyzed incidence and remission rates of TD and EPS in a predominantly SGA treated population of patients with schizophrenia.

The analysis revealed a low incidence of newly diagnosed EPS and TD, in line with previous reports of lower incidence of TD and EPS with SGA treatment (Correll, Leucht et al. 2004). There was, however, a large proportion of patients who, having developed EPS and TD under SGA treatment, displayed very persistent symptoms. The rate of persistence of TD in the current report was higher than that published in an earlier report relating to the same cohort, where persistence of TD was lower for the SGA than the FGA cohort, and where we speculated SGA to have ameliorating properties (Tenback, van Harten et al. 2005). A hypothesis is proposed to explain the high persistence of TD after having emerged under SGA treatment.

\section{A Theory of Gradual Dopamine Hypersensitivity.}

The dopamine theory was formulated almost thirty years ago, following the observation that drugs which increased dopamine, enhanced or produced positive symptoms, whereas a blockade of dopamine receptors diminished existent positive symptoms (Gerlach 1977; Davis, Kahn et al. 1991). We propose a refinement of the dopamine hypothesis, where TD and EPS are core symptoms of schizophrenia and possible markers for the course of the disease (Murray and Van Os 1998), and gradually increasing dopamine $(\mathrm{D}(2))$ receptor sensitivity is a marker for schizophrenia disease severity. Thus, we suggest TD and EPS not to be adverse events of antipsychotic treatment, but rather to represent pathophysiological markers for the disease itself. Earlier reports indicated pandopaminergic involvement in developing TD, with dose response relationships between the derived adverse events representing the different dopamine tracts and incident TD (Tenback, van Harten et al. 2005; Tenback, van Harten et al. 2006; Tenback, van Harten et al. 2006)

With SGA we consistently find a lower incidence of TD and EPS. Where TD does occur, it seemingly has a high persistence, due to a gradually developing dopamine supersensitivity. This supersensitivity can be described as: i) mild: patient will probably not develop TD; ii) moderate: patient will develop TD under the influence of moderate stressors of the dopamine system such as FGA, TD can possibly be reversed by taking SGA; iii) marked: patient will develop TD with mild environmental provocation such as SGA; iv) severe: patient will develop TD, with or without environmental provocation such as antipsychotic medication. Thus when developing TD and EPS on FGA, a proportion of patients with a less supersensitive dopamine system could still respond to treatment of TD symptoms with SGA. Patients with a highly supersensitive dopamine system however, will eventually develop TD while on SGA, and will subsequently be persistent in TD and EPS symptoms. 


\section{CONCLUSION}

Tardive Dyskinesia in schizophrenia is not just an adverse event of antipsychotic treatment; it should rather be described as representing a pathophysiological marker for the disease itself. TD can be considered as a marker for disease severity and prognosis.

In a large cohort of patients with schizophrenia we have shown that the emergence of TD can at least partly be explained by proxy measures indicative of a pandopaminergic involvement probably reflecting a gradual pandopaminergic hypersensitivity.

This pandopaminergic hypersensitivity is best understood by a model of gradual dopamine hypersensitivity. Although further research should validate the concept of pandopaminergic hypersensitivity, early EPS and TD could be useful early markers for disease prognosis and therefore have possible implications with regard to pharmacological treatment options, early treatment intervention, and expected burden of care. 


\section{REFERENCES}

Casey, D. E. (2004). "Pathophysiology of antipsychotic drug-induced movement disorders." J Clin Psychiatry 65 Suppl 9: 25-8.

Chakos, M. H., J. M. Alvir, et al. (1996). "Incidence and correlates of tardive dyskinesia in first episode of schizophrenia." Arch Gen Psychiatry 53(4): 313-9.

Chatterjee, A., M. Chakos, et al. (1995). "Prevalence and clinical correlates of extrapyramidal signs and spontaneous dyskinesia in never-medicated schizophrenic patients." Am J Psychiatry 152(12): 1724-9.

Chouinard, G., L. Annable, et al. (1988). "A 5-year prospective longitudinal study of tardive dyskinesia: factors predicting appearance of new cases." J Clin Psychopharmacol 8(4 Suppl): 21S-26S.

Correll, C. U., S. Leucht, et al. (2004). "Lower risk for tardive dyskinesia associated with secondgeneration antipsychotics: a systematic review of 1-year studies." Am J Psychiatry 161(3): 414-25.

Davis, J. M., N. Chen, et al. (2003). "A meta-analysis of the efficacy of second-generation antipsychotics." Arch Gen Psychiatry 60(6): 553-64.

Davis, K. L., R. S. Kahn, et al. (1991). "Dopamine in schizophrenia: a review and reconceptualization." Am J Psychiatry 148(11): 1474-86.

Egan, M. F., T. M. Hyde, et al. (2001). "Relative risk of neurological signs in siblings of patients with schizophrenia." Am J Psychiatry 158(11): 1827-34.

Fenton, W. S. (2000). "Prevalence of spontaneous dyskinesia in schizophrenia." J Clin Psychiatry 61 Suppl 4: 10-4.

Gerlach, J. (1977). "The relationship between parkinsonism and tardive dyskinesia." Am J Psychiatry 134(7): 781-4.

Haddad, P. M. and A. Wieck (2004). "Antipsychotic-induced hyperprolactinaemia: mechanisms, clinical features and management." Drugs 64(20): 2291-314.

Halbreich, U., B. J. Kinon, et al. (2003). "Elevated prolactin levels in patients with schizophrenia: mechanisms and related adverse effects." Psychoneuroendocrinology 28 Suppl 1: 53-67.

Hirvonen, J., T. G. van Erp, et al. (2005). "Increased caudate dopamine D2 receptor availability as a genetic marker for schizophrenia." Arch Gen Psychiatry 62(4): 371-8.

Ismail, B., E. Cantor-Graae, et al. (2001). "Neurodevelopmental origins of tardivelike dyskinesia in schizophrenia patients and their siblings." Schizophr Bull 27(4): 629-41.

Kessler, R. M., M. S. Ansari, et al. (2005). "Occupancy of Striatal and Extrastriatal Dopamine $\mathrm{D}(2) / \mathrm{D}(3)$ Receptors by Olanzapine and Haloperidol." Neuropsychopharmacology.

Knegtering, H., A. E. van der Moolen, et al. (2003). "What are the effects of antipsychotics on sexual dysfunctions and endocrine functioning?" Psychoneuroendocrinology 28 Suppl 2: 109-23.

Leucht, S., T. R. Barnes, et al. (2003). "Relapse prevention in schizophrenia with new-generation antipsychotics: a systematic review and exploratory meta-analysis of randomized, controlled trials." Am J Psychiatry 160(7): 1209-22.

Murray, R. M. and J. Van Os (1998). "Predictors of outcome in schizophrenia." J Clin Psychopharmacol 18(2 Suppl 1): 2S-4S.

Sachdev, P. (2004). "Early extrapyramidal side-effects as risk factors for later tardive dyskinesia: a prospective study." Aust N Z J Psychiatry 38(6): 445-9.

Schroder, J., S. Silvestri, et al. (1998). "D2 dopamine receptor up-regulation, treatment response, neurological soft signs, and extrapyramidal side effects in schizophrenia: a follow-up study 
with 123I-iodobenzamide single photon emission computed tomography in the drug-naive state and after neuroleptic treatment." Biol Psychiatry 43(9): 660-5.

Silvestri, S., M. V. Seeman, et al. (2000). "Increased dopamine D2 receptor binding after longterm treatment with antipsychotics in humans: a clinical PET study." Psychopharmacology (Berl) 152(2): 174-80.

Tenback, D. E., P. N. van Harten, et al. (2005). "Effects of Antipsychotic Treatment on Tardive Dyskinesia: A 6-Month Evaluation of Patients From the European Schizophrenia Outpatient Health Outcomes (SOHO) Study." J Clin Psychiatry 66(9): 1130-1133.

Tenback, D. E., P. N. van Harten, et al. (2006). "Tardive dyskinesia in schizophrenia is associated with prolactin-related sexual disturbances." Neuropsychopharmacology 31(8): 1832-7.

Tenback, D. E., P. N. van Harten, et al. (2006). "Evidence That Early Extrapyramidal Symptoms Predict Later Tardive Dyskinesia: A Prospective Analysis of 10,000 Patients in the European Schizophrenia Outpatient Health Outcomes (SOHO) Study." Am J Psychiatry 163(8): 143840.

Tenback, D. E., P. N. van Harten, et al. (2006). "Tardive Dyskinesia and Worsening of Psychosis: More than Just the Nigrostriatal Dopamine Tract?" submitted to Acta Psychiatr Scand. 


\section{CHAPTER 10}

\section{Summary}

The main hypothesis of this thesis is the existence of a pandopaminergic D2 hypersensitivity in schizophrenia, influenced by exogenous factors. To support or refute this hypothesis the following issues were addressed: i) the current body of evidence for risk factors for TD in schizophrenia; ii) the relationship between exogenous (risk) factors and TD; iii) the possibility of longitudinal associations of TD with proxies for the different D2 dopaminergic tracts.

Chapter 1 provides a background for and definitions of schizophrenia, and briefly describes the objective and the intended direction of this thesis.

Chapter 2 describes the methodology and treatment characteristics of the SOHO study. General considerations with regard to the scientific merits of observational and the, more rigorous, experimental designs are discussed. Next, more specifically, the limitations of the way in which the data of the SOHO study was designed and analyzed are reflected upon. Use patterns of the SOHO study are reported on as well, these consist of: i) use and compliance patterns for the several types of antipsychotic medication and ii) use patterns of concomitant medication in the course of the SOHO study. This information provides a better insight into the cohort on which all analyses were performed. Finally we provide a list of covariates used in all analyses, as decided upon by the SOHO advisory board

Chapter 3 reports on a meta-analysis performed on risk factors for TD. There is a large number of papers on risk factors for Tardive Dyskinesia (TD), varying in both direction and size of risk estimates. Most studies on risk factors, however, are cross sectional and conducted in mixed populations. To obtain a true estimate of risk for new onset of TD in patients suffering from non-affective psychotic disorder, we performed a meta-analytic study exclusively focusing on true (i.e. prospectively assessed) incidence of TD in patients who, for the majority, were diagnosed with schizophrenia. Besides FGA, only akathisia remained as a risk factor for emergent TD in a fixed and random effects model.

Chapter 4 presents the findings of a study dealing with the comparative effects of FGA versus SGA on incidence of newly emergent TD and persistence of TD in patients already afflicted with the disorder. Data at baseline, three months and six months were analyzed using a generalized estimating equation (GEE) model. Patients on SGA showed a markedly lower incidence of TD, moreover, in patients afflicted with TD, a lower persistence of TD symptoms was noted for SGA in comparison to FGA. 
Chapter 5 deals with the question of early extrapyramidal symptoms (EPS) as a risk factor for TD. In our meta analysis in chapter 3, early EPS predicted TD in the Fixed Effect model, but not in the Random Effects model. In order to accept or reject the hypothesis of early EPS as a risk factor for TD, baseline, three-, six- and twelve month data for 9298 patients were analyzed using a Cox proportional hazard model. The results provided strong support for the view that early EPS is a risk factor for the emergence of TD. Early EPS as a risk factor for TD implicates involvement of the nigrostriatal dopamine tract.

Chapter 6 introduces the concept that more dopamine tracts than just the nigrostriatal tract could be involved in the emergence of TD. To support this hypothesis we tested whether, independent of the antipsychotic-induced rise in prolactin, the incidence of TD could be associated with the incidence of prolactin-related sexual disturbances (PRSD). New onset of TD and new onset of PRSD at three, six and twelve months were analyzed in a risk set of 4263 patients using a Cox proportional hazard model. The results supported the concept that more dopamine tracts than the nigrostriatal tract alone can be involved in the emergence of TD; incidence of TD was significantly and linearly comorbid with the incidence of PRSD and associations were stronger in those who only had received prolactin-sparing medications. Therefore, the fact that survival without TD was at best only weakly associated with newly arising PRSD in those exposed to prolactin-raising medications suggests that the rise in prolactin, occasioned by antipsychotic medications, is not the common mechanism causing TD and PRSD to cluster over time; their simultaneous clustering over time in those exposed to prolactin-sparing medications much rather suggests an underlying common and central vulnerability, involving more than one central dopamine tract.

The aim of the study described in chapter 7 was to examine a proxy psychopathological measure of dopaminergic mesolimbic and mesocortical signalling in relation to the incidence of tardive dyskinesia (TD), and test the hypothesis that besides the nigrostriatal and tuberoinfundibular dopamine tract, further dopamine tracts contribute to variation in abnormal movements in patients with schizophrenia. Simple, global, measures of TD and CGI positive, negative, affective and cognitive symptoms, were best represented by a single CGI overall symptom severity score, as a principal component factor analysis of the four dimensions of positive, negative, depressive, and cognitive symptoms revealed only one main global factor with an eigenvalue greater than unity on which all dimensions had high loadings, explaining $63 \%$ of the variance. In a risk set of 8620 patients free of TD at baseline, associations between TD onset and change in CGI scores, hypothesized to reflect underlying changes in neurochemical signalling, were assessed using Cox proportional hazard regression. To the extent that changes in symptoms reflect underlying alterations in dopaminergic mesolimbic and mesocortical signalling, worsening in overall psychopathology in schizophrenia predicts emergence of TD, suggesting the mesolimbic and mesocortical dopamine tract to be involved in the emergence of TD. 
Chapter 8 reports on an analysis to assess the morbidity force of movement disorder in the era of second generation antipsychotics (SGA), by calculating the incidence and persistence of Tardive Dyskinesia (TD) and Extra Pyramidal Symptoms (EPS) in a cohort of patients with schizophrenia, treated predominantly with SGA, over a period of two years. Dichotomous measures of EPS and TD were used to calculate the cumulative incidence rates of TD and EPS, as well as their subsequent persistence rate. In line with previous publications, incidence rates of TD and EPS are considerably lower in the SGA era. However, once emerged, these disorders prove highly persistent, suggesting strong moderator effects of underlying predisposing factors. To explain these strong moderator effects, a hypothesis is proposed where TD and EPS are core symptoms of schizophrenia and possible markers for the course of the disease, and where gradually increasing dopamine $(\mathrm{D}(2))$ receptor sensitivity can be considered as a marker for schizophrenia disease severity.

Although further research should validate the concept of gradually increasing dopamine $(\mathrm{D}(2))$ receptor sensitivity, early EPS and TD could be useful early markers for disease prognosis, and thus make it possible to consider implications with regard to pharmacological treatment options, early treatment intervention and expected burden of care. 


\section{CHAPTER 11}

\section{Samenvatting}

De centrale hypothese van dit proefschrift is een pandopaminerge hypersensitiviteit bij schizofrenie (beïnvloed door exogene factoren). Om deze hypothese te toetsen werden de volgende vraagstellingen onderzocht: i) is er in de hedendaagse literatuur sluitend bewijs voor risico factoren voor het optreden van Tardieve Dyskinesie (TD) bij patiënten waarbij schizofrenie is gediagnosticeerd, ii) hoe is de relatie tussen exogene risicofactoren en TD, en tenslotte, iii) zijn er longitudinale associaties tussen TD en afgeleide meetwaarden die de verschillende dopamine (D2) banen representeren.

Hoofdstuk 1 schetst beknopt de achtergrond van schizofrenie en beschrijft de gehanteerde definities. In het kort worden doel en opzet van het proefschrift besproken.

Hoofdstuk 2 beschrijft de methodologie en de behandelkarakteristieken van de SOHO studie. Algemene overwegingen met betrekking tot de opzet van het onderzoek, de gehanteerde analyses en de hieraan gekoppelde wetenschappelijke waarde worden aangegeven. Om een beter inzicht te verkrijgen in de patiëntenpopulatie waarop alle analyses werden verricht, wordt een tabel gepresenteerd met demografische en behandelgegevens van het $\mathrm{SOHO}$ cohort. Tenslotte volgt een tabel met een overzicht van alle covariaten, zoals deze door de SOHO adviesraad werden geselecteerd om te verwerken in de analyses.

Hoofdstuk 3 behandelt een meta-analyse verricht naar de evidentie van risico factoren voor het optreden van TD bij schizofrenie. Er is een grote hoeveelheid studies over risicofactoren bij TD. Niet alleen verschillen de in deze studies gevonden risico factoren, ook de grootte van het risico en zelfs richting van het effect (beschermend of daadwerkelijk een risicofactor) verschillen onderling. Een verklaring hiervoor zou kunnen zijn dat de meeste studies cross-sectioneel zijn, waardoor niet kan worden bepaald of een gevonden variabele een risico factor is voor het optreden of juist het aanhouden van TD. Bovendien werden de studies verricht in verschillend gedefinieerde psychiatrische populaties. De verschillende psychiatrische populaties zijn een belangrijke factor, gezien onze hypothese dat het optreden van TD bij schizofrenie gebaseerd is op een gradueel oplopende dopamine (D2) receptor sensitiviteit. TD in andere psychiatrische stoornissen, zoals psychotische depressie of vormen van dementie waarbij antipsychotica worden voorgeschreven, zou TD een bijwerking van de medicatie kunnen zijn en/of een andere pathofysiologische basis kunnen hebben. 
Om het risico van het optreden van TD nauwkeurig in te kunnen schatten, werd het zwaartepunt van onze meta analyse gelegd bij patiënten die prospectief onderzocht waren op het ontstaan van TD en waarbij bij het merendeel schizofrenie was gediagnosticeerd.

Naast eerste generatie antipsychotica, reeds bekend als risicofactor uit een eerdere meta analyse, bleek alleen akathisie een additionele voorspeller voor het optreden van TD zowel in een fixed als in een random effects model.

Hoofdstuk 4 beschrijft een onderzoek waarin de eerste versus de tweede generatie antipsychotica worden vergeleken met betrekking tot: i) het ontstaan van TD bij patiënten met schizofrenie zonder verschijnselen van TD bij aanvang van de studie en ii) het persisteren van TD bij patiënten die reeds verschijnselen van TD vertonen bij aanvang van de studie.

Conform de verwachting lieten de tweede generatie antipsychotica een aanmerkelijk lagere incidentie zien van nieuw ontstane TD, een nieuwe bevinding in vergelijkend onderzoek was het minder persisteren van verschijnselen van TD bij de tweede generatie antipsychotica.

In hoofdstuk 5 staat de vraag centraal of het optreden van vroege extrapiramidale symptomen (EPS) een risico factor is voor het ontstaan van TD. In de meta analyse van hoofdstuk 3 voorspelde vroege EPS TD in een fixed, maar niet in een random effects model. Om nader aan te tonen dat vroege EPS als risico factor voor TD al dan niet bestaat, werd in de SOHO studie een Cox regressie analyse verricht op de data van 9298 patiënten verzameld bij aanvang, drie, zes en twaalf maanden. Het resultaat onderbouwde de stelling dat vroege EPS een belangrijke voorspeller is van nieuw ontstane TD. EPS is een fenomeen dat geassocieerd wordt met de nigrostriatale dopamine baan en impliceert derhalve een rol van de nigrostriatale baan bij het ontstaan van verschijnselen van TD.

In hoofdstuk 6 wordt het concept dat naast de nigrotriatale dopamine baan meer dopamine banen betrokken kunnen zijn bij het ontstaan van TD verder onderbouwd. Om dit concept kracht bij te zetten toetsten wij de hypothese of, onafhankelijk van prolactine verhogingen geïnduceerd door antipsychotica, de incidentie van Prolactine Gerelateerde Seksuele Bijwerkingen (PGSB) longitudinaal geassocieerd zijn met het ontstaan van TD.

Voor het onderzoeken van deze longitudinale associatie werd een Cox regressie analyse verricht bij 4263 patiënten zonder verschijnselen van PGSB of TD bij aanvang van de studie. Het resultaat liet een longitudinaal verband zien tussen nieuw ontstane TD en PGSB, bovendien was er sprake van een dosis respons relatie. Dit verband was sterker bij prolactine sparende dan bij prolactine verhogende medicatie, waaruit blijkt dat prolactine verhoging geïnduceerd door antipsychotische medicatie niet verklaart waarom TD en PGSB samenhangen in de tijd, maar dat de verklaring hiervoor gezocht moet worden in de betrokkenheid van de tuberoinfundibulaire dopamine baan zelf. De resultaten ondersteunen het concept dat meer dopamine (D2) banen een gevoeligheid hebben voor en betrokken zijn bij het ontstaan van TD. 
Hoofdstuk 7 beschrijft een onderzoek dat tot doel heeft de hypothese van de betrokkenheid van meerdere dopamine banen bij het ontstaan van TD verder te onderbouwen. Er wordt onderzocht of een afgeleide maat voor de mesolimbische en mesocorticale dopamine baan longitudinaal geassocieerd is met het ontstaan van TD, In de SOHO studie zijn clusters van symptomen, positieve, negatieve, affectieve en cognitieve, gemeten per symptoom cluster door middel van een CGI (Clinical Global Impression), ook werd de algehele ernst van het ziektebeeld vastgelegd in een CGI algehele ernst schaal. Een factor analyse wees uit dat de verschillende symptoom clusters het best vertegenwoordigd werden door de CGI algehele ernst schaal, welke $63 \%$ van de totale variantie verklaarde. Hieruit volgt dat in plaats van de CGI positieve symptomen voor de mesolimbische dopamine baan en CGI cognitieve en negatieve symptomen voor de mesocorticale banen, het de voorkeur verdient voor de analyse de CGI algehele ernstschaal, welke representatief verondersteld wordt voor de mesolimbische en mesocorticale dopamine banen, te gebruiken. Een Cox regressie analyse werd vervolgens gebruikt om bij 8620 patiënten zonder verschijnselen van Tardieve Dyskinesie bij aanvang van de studie, de relatie te onderzoeken tussen veranderingen van de CGI algehele ernst schaal en het ontstaan van TD. Hierbij werd uitgegaan van de aanname dat de veranderingen in de CGI en TD scores een afspiegeling zijn van de respectieve dopamine banen.

Het resultaat van de analyse laat zien dat indien veranderingen van de symptomen inderdaad een weerspiegeling zijn van het mesolimbisch en mesocorticaal dopamine systeem, het verslechteren van de algehele psychopathologie het ontstaan van TD voorspelt, hetgeen tevens een betrokkenheid van het mesolimbische en mesocorticale systeem suggereert.

Hoofdstuk 8 behandelt een analyse met als doelstelling te bepalen in welke mate een gevoeligheid voor TD zich kan manifesteren in het tijdperk van de tweede generatie antipsychotica. Incidentie van nieuw ontstane TD en EPS en het persisteren van symptomen van TD en EPS bij patiënten die reeds aan deze bewegingsstoornissen lijden, worden berekend bij patiënten die al twee jaar worden behandeld met voornamelijk tweede generatie antipsychotica.

Conform de bevindingen in eerdere studies zijn de incidentie cijfers van TD en EPS aanmerkelijk lager in het tijdperk van de tweede generatie antipsychotica. Opmerkelijk echter is het feit, dat wanneer TD en EPS optreden in het tijdperk van de tweede generatie antipsychotica, deze lijken te persisteren, hetgeen suggereert dat er sterk modererende effecten van onderliggende, predisponerende, factoren een rol spelen.

Een verklaringsmodel wordt voorgesteld waarin TD en EPS basissymptomen zijn van schizofrenie in plaats van enkel en alleen medicatie effecten. TD en EPS als basissymptomen van schizofrenie zijn vroege voorspellers voor de behandelbaarheid en het verloop van de ziekte. Gradueel oplopende dopamine (D2) sensitiviteit kan worden beschouwt als een voorspeller van de ernst van de ziekte.

Hoewel verder onderzoek het concept van een gradueel oplopende dopamine (D2) receptor sensitiviteit nader moet onderbouwen, zijn TD en EPS goed te gebruiken als vroege voorspellers van het verloop en de prognose van schizofrenie. Deze vroege signalen maken het mogelijk rationele beslissingen te nemen ten aanzien 
van farmacotherapie en vroege interventie en geven tevens inzicht in de te verwachten zorgzwaarte. 


\section{Dankwoord}

Vele mensen hebben geholpen bij de totstandkoming van dit proefschrift. Mijn dank gaat uit naar al deze mensen.

Jim van Os als promotor, met een ongekende inzet, kennis, enthousiasme, snelheid van respons, accuratesse, bekwaamheid en bevlogenheid. Bedankt voor de goede ervaring en leiding die je gegeven hebt.

Cees Slooff wil ik als copromotor bedanken voor zijn stimulerende houding, inzicht en inzet, hij is degene die mij heeft aangezet om te starten met dit proefschrift. Peter van Harten, mijn tweede copromotor, bedank ik voor de discussies en waardevolle inzichten die hebben bijgedragen tot een verbeterde kwaliteit van dit proefschrift.

De leden van de beoordelingscommissie wil ik graag bedanken voor hun bereidheid om zitting te nemen in de beoordelingscommissie en het verrichten van alle daarbij behorende taken.

Mijn lieve gezin, Marie-Louise, Alexander, Josephine en Philip. Jullie zijn een fantastische steun geweest en een grote bron van vreugde in een tijd waarin ik soms niet helemaal door had wat er in de buitenwereld omging.

Mijn moeder Charlotte en mijn stiefmoeder Eva, de ene voor haar ondersteuning, bezorgdheid en het ontwerp van de kaft van mijn proefschrift, de andere voor het corrigeren van mijn engelse taal met een bewonderenswaardige vasthoudendheid.

Mijn grote vriend Boudewijn, voor het naast me blijven staan terwijl de frequentie van contact drastisch instortte in de afgelopen drie jaar.

De firma Lilly waar ik een leuke en leerzame werkplek heb gehad en waar ik mee heb mogen werken aan het opzetten en uitvoeren van de SOHO studie. Ook heeft Lilly mij, na mijn terugkeer naar de psychiatrie, het vertrouwen geschonken om met de SOHO database te mogen werken voor het voorbereiden en schrijven van dit proefschrift. De medewerkers van Lilly die ik in het bijzonder wil ik noemen zijn: Maarten Boomsma voor zijn altijd goede humeur en positieve kijk op het leven en daarnaast zijn inzet om dit samenwerkingsproject naadloos te laten verlopen . Rudolph van Olden en Joep Huige voor het ondersteunen van de samenwerking, en Diego Novick en Mark Belger voor de ondersteuning vanuit Lilly Erlwood.

De gehele SOHO Advisory Board wil ik graag bedanken voor hun constructieve kritiek op de artikelen van dit proefschrift. Mijn speciale dank gaat uit naar de volgende leden van de Advisory Board: Jean-Pierre Lepine, Isabelle Gasquet, Dieter Naber, Cees Slooff, Jordi Alonso, Josep Maria Haro, Peter Jones, Tim Croudace en Martin Knapp.

Mijn collegae psychiaters en neuropsychologen van het RPC Woerden dank ik voor het lezen en corrigeren van gedeelten van het manuscript (Pieter Beijaert, Henk Jan van Vliet, Anneliek Maat, Addy Pulles en Ineke Brands).

Tenslotte wil ik Leni Noteborn bedanken voor haar inzet in de logistiek rondom de procedures van mijn proefschrift en Piet Oosthuizen voor het delen van zijn prachtige first episode studie data ten behoeve van de meta analyse. 


\section{Curriculum vitae}

Diederik Tenback werd op 25 augustus 1964 geboren in Poortugaal. Na het behalen van het diploma VWO in 1984 ging hij geneeskunde studeren aan de Rijksuniversiteit van Groningen. Het artsexamen werd afgelegd in 1991.

$\mathrm{Na}$ ervaring opgedaan te hebben in psychiatrie en neurologie volgde hij de opleiding tot psychiater, die werd afgerond in 1999. Van 2000 tot 2003 was hij werkzaam bij Eli Lilly als Clinical Research Physician en betrokken bij het opzetten en uitvoeren van de SOHO studie. Gedurende deze tijd werd het Diploma Pharmaceutical Medicine behaald aan de Welsh School of Pharmacy bij de Universiteit van Wales. In 2003 verliet hij Eli Lilly om weer als psychiater te gaan werken bij Altrecht. In 2003 startte hij zijn promotieonderzoek.

Vanaf 2004 volgt hij de opleiding epidemiologie van het EMGO Instituut. 


\section{List of publications}

Articles:

Leeuw, M. de, F. Peeters \& D. Tenback. "A 'depression day' for patients and caregivers"

MGv 2000 (volume 55) 5, p.445-450

Tenback D, de Jong J, Nolen W. De behandeling van manie; een observationeel onderzoek. Patient Care Maart 2003.

Tenback, D. E., P. N. van Harten, et al. (2005). "Effects of Antipsychotic Treatment on Tardive Dyskinesia: A 6-Month Evaluation of Patients From the European Schizophrenia Outpatient Health Outcomes (SOHO) Study." J Clin Psychiatry 66(9): 1130-1133.

Tenback, D. E., P. N. van Harten, et al. (2006). "Evidence That Early Extrapyramidal Symptoms Predict Later Tardive Dyskinesia: A Prospective Analysis of 10,000 Patients in the European Schizophrenia Outpatient Health Outcomes (SOHO) Study." Am J Psychiatry 163(8): 1438-40.

Tenback, D. E., P. N. van Harten, et al. (2006). "Tardive dyskinesia in schizophrenia is associated with prolactin-related sexual disturbances." Neuropsychopharmacology 31(8): 1832-7.

G.B. van de Kraats, J.Slob, D.E. Tenback. Potentieel levensbedreigende aritmieën bij de behandeling van psychiatrische stoornissen met QTc-tijd verlengende medicatie. Accepted Tijdschrift voor Psychiatrie.

M. Oosterhuis, G.B. van de Kraats, D.E. Tenback. Safety of Aripiprazole; high serum levels in a CYP2D6 mutated patient. Accepted Am J Psychiatry.

\section{Posters}

Kölling P, Tenback D, Slooff CJ. Verschillen tussen de geslachten bij schizofrenie patiënten in Nederland: resultaten van het Schizophrenia Outpatient Health Outcomes (SOHO) onderzoek. Voorjaarscongres 2003

Tenback DE, van Harten PN, Slooff CJ, van Os J: Tardive Dyskinesia in Schizophrenia is Associated with Prolactin-Related Sexual Disturbances. Schizophrenia Research 2006 
Tenback DE, van Harten PN, Slooff CJ, Van Os J, and the SOHO Study Group: Tardive Dyskinesia and Worsening of Psychosis: More than Just the Nigro-Striatal Dopamine Tract? Voorjaarscongres 2006

Inge van Rossum, Josep Maria Haro, Diederik Tenback, Maarten Boomsma, Iris Goetz, Eduard Vieta, Jim van Os. Treatment outcome in distinct classes of mania. CINP Chigaco 2006

Novick D, Haro JM , Suarez D, Bushe C, Tenback D, van Os J and the SOHO Advisory Board. Development of Tardive Dyskinesia in the Outpatient Treatment of Schizophrenia: 36 months results from the European Schizophrenia Health Outcomes (SOHO) Study.

British Association of Psychopharmacology 2006, Summer Meeting Oxford, U.K. 